Issued by Sandia National Laboratories, operated for the United States

Department of Energy by Sandia Corporation.

NOTICE: This report was prepared as an account of work sponsored by an agency of the United States Government. Neither the United States Government, nor any agency thereof, nor any of their employees, nor any of their contractors, subcontractors, or their employees, make any warranty, express or implied, or assume any legal liability or responsibility for the accuracy, completeness, or usefulness of any information, apparatus, product, or process disclosed, or represent that its use would not infringe privately owned rights. Reference herein to any specific commercial product, process, or service by trade name, trademark, manufacturer, or otherwise, does not necessarily constitute or imply its endorsement, recommendation, or favoring by the United States Government, any agency thereof, or any of their contractors or subcontractors. The views and opinions expressed herein do not necessarily state or reflect those of the United States Government, any agency thereof, or any of their contractors.

Printed in the United States of America. This report has been reproduced directly from the best available copy.

Available to DOE and DOE contractors from

U.S. Department of Energy

Office of Scientific and Technical Information

P.O. Box 62

Oak Ridge, TN 37831

Telephone: (865)576-8401

Facsimile: (865)576-5728

E-Mail: reports@adonis.osti.gov

Online ordering: http://www.doe.gov/bridge

Available to the public from

U.S. Department of Commerce

National Technical Information Service

5285 Port Royal Rd

Springfield, VA 22161

Telephone: $(800) 553-6847$

Facsimile: (703)605-6900

E-Mail: orders@ntis.fedworld.gov

Online order: http://www.ntis.gov/ordering.htm

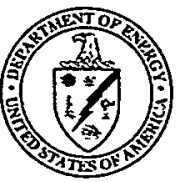




\section{DISCLAIMER}

\section{Portions of this document may be illegible in electronic image products. Images are produced from the best available original document.}


SAND 2000-2109

Unlimited Release

Printed August 2000

\title{
Segmented Aluminum Honeycomb Characteristics in T-Direction, Dynamic Crush Environments
}

\author{
Vesta I. Bateman, Fred A. Brown, Michael A. Nusser \\ and Lloyd $\mathrm{H}$. Swanson \\ Engineering Sciences Center \\ Sandia National Laboratories \\ P. O. Box 5800 \\ Albuquerque, NM 87185-0553
}

\section{Abstract}

Thirteen segmented aluminum honeycomb samples ( 5 in. diameter and $1.5 \mathrm{in}$. height) have been crushed in an experimental configuration that uses a drop table impact machine. The 38.0 pcf bulk density samples are a unique segmented geometry that allows the samples to be crushed while maintaining a constant cross-sectional area. A crush weight of $175 \mathrm{lb}$ was used to determine the rate sensitivity of the honeycomb's highest strength orientation, T-direction, in a dynamic environment of $\approx 50 \mathrm{fps}$ impact velocity. Experiments were conducted for two honeycomb manufacturers and at two temperatures, ambient and $+165^{\circ} \mathrm{F}$. Independent measurements of the crush force were made with a custom load cell and a force derived from acceleration measurements on the drop table using the Sum of Weighted Accelerations Technique with a Calibrated Force (SWAT-CAL). Normalized stress-strain curves for all thirteen experiments are included and have excellent repeatability. These data are strictly valid for material characteristics in the $\mathrm{T}$ orientation because the cross-sectional area of the honeycomb did not change during the crush. The dynamic crush data have a consistent increase in crush strength of $~ 7-19 \%$ as compared to quasi-static data and suggest that dynamic performance may be inferred from static tests. An uncertainty analysis estimates the error in these data is $\pm 11 \%$. 


\section{Contents}

Abstract $\quad 3$

Introduction $\quad 8$

Experimental Configuration 99

Experimental Results $\quad 17$

Uncertainty Analysis $\quad 23$

$\begin{array}{ll}\text { Conclusions } & 23\end{array}$

Acknowledgements $\quad 24$

References $\quad 33$

\section{Appendix}

A Load Cell Static Calibration and Modal Analysis Results 34

Load Cell Static Calibration. $\quad 35$

Load Cell Static Calibration Configuration on Tinius Olsen Machine. $\quad 36$

Undeformed Load Cell Model (Solid Works) with Coordinate System. $\quad 37$

Results of Two Modal Analyses for the Load Cell. 38

B Comparison of DC-2000 Hz and DC-10,000 Hz SWAT-CAL and Load 39

Cell Derived Stress Time History and Fourier Transforms (One

Experiment from Each Set).

SWAT-CAL Stress Comparison: Solid - DC-2000 Hz and Dash - DC- 40

$10,000 \mathrm{~Hz}$ (Segmented Alcore Honeycomb at $+165^{\circ} \mathrm{F}$ Temperature).

Load Cell Stress Comparison: Solid - DC-2000 Hz and Dash - DC-10,000 41

$\mathrm{Hz}$ (Segmented Alcore Honeycomb at $+165^{\circ} \mathrm{F}$ Temperature).

SWAT-CAL Stress Comparison: Solid - DC-2000 Hz and Dash - DC-

$10,000 \mathrm{~Hz}$ (Segmented Alcore Honeycomb at Ambient Temperature).

Load Cell Stress Comparison: Solid - DC-2000 Hz and Dash - DC-10,000 43

$\mathrm{Hz}$ (Segmented Alcore Honeycomb at Ambient Temperature).

SWAT-CAL Stress Comparison: Solid - DC-2000 Hz and Dash - DC-

$10,000 \mathrm{~Hz}$ (Segmented Hexcel Honeycomb at $+165^{\circ} \mathrm{F}$ Temperature).

Load Cell Stress Comparison: Solid - DC-2000 Hz and Dash - DC-10,000

$\mathrm{Hz}$ (Segmented Hexcel Honeycomb at $+165^{\circ} \mathrm{F}$ Temperature).

SWAT-CAL Stress Comparison: Solid - DC-2000 Hz and Dash - DC-

$10,000 \mathrm{~Hz}$ (Segmented Hexcel Honeycomb at Ambient Temperature).

Load Cell Stress Comparison: Solid - DC-2000 Hz and Dash - DC-10,000

$\mathrm{Hz}$ (Segmented Hexcel Honeycomb at Ambient Temperature). 


\section{Appendix (cont.)}

C Comparison SWAT-CAL and Load Cell Derived Stress Time History and Fourier Transforms, DC-2000 Hz Bandwidth (One Experiment from Each Set).

SWAT-CAL - Solid and Load Cell - Dash Stress Comparison, DC-2000

$\mathrm{Hz}$ Bandwidth (Segmented Alcore Honeycomb at $+165^{\circ} \mathrm{F}$

Temperature).

SWAT-CAL - Solid and Load Cell - Dash Stress Comparison, DC-2000

$\mathrm{Hz}$ Bandwidth (Segmented Alcore Honeycomb at Ambient

Temperature).

SWAT-CAL - Solid and Load Cell - Dash Stress Comparison, DC-2000

$\mathrm{Hz}$ Bandwidth (Segmented Hexcel Honeycomb at $+165^{\circ} \mathrm{F}$

Temperature).

SWAT-CAL - Solid and Load Cell - Dash Stress Comparison, DC-2000

- Hz Bandwidth (Segmented Hexcel Honeycomb at Ambient

Temperature).

D - Normalized Segmented Honeycomb Crush Characteristics

53

SWAT-CAL Stress Comparison, DC-2000 Hz Bandwidth (Segmented

Alcore Honeycomb at $+165^{\circ} \mathrm{F}$ Temperature).

Load Cell Stress Comparison, DC-2000 Hz Bandwidth (Segmented

Alcore Honeycomb at $+165^{\circ} \mathrm{F}$ Temperature).

SWAT-CAL Stress Comparison, DC-2000 Hz Bandwidth (Segmented

Alcore Honeycomb at Ambient Temperature).

Load Cell Stress Comparison, DC-2000 Hz Bandwidth (Segmented

Alcore Honeycomb at Ambient Temperature).

SWAT-CAL Stress Comparison, DC-2000 Hz Bandwidth (Segmented

Hexcel Honeycomb at $+165^{\circ} \mathrm{F}$ Temperature).

Load Cell Stress Comparison, DC-2000 Hz Bandwidth (Segmented

Hexcel Honeycomb at $+165^{\circ} \mathrm{F}$ Temperature).

SWAT-CAL Stress Comparison, DC-2000 Hz Bandwidth (Segmented

Hexcel Honeycomb at Ambient Temperature).

Load Cell Stress Comparison, DC-2000 Hz Bandwidth (Segmented

- Hexcel Honeycomb at Ambient Temperature).

E Pictures of Crushed Segmented Honeycomb Samples.

Experiment 1: Segmented Alcore Honeycomb at $+165^{\circ} \mathrm{F}$ Temperature.

Experiment 2: Segmented Alcore Honeycomb at $+165^{\circ} \mathrm{F}$ Temperature. 


\section{Appendix (cont.)}

Experiment 3: Segmented Alcore Honeycomb at $+165^{\circ} \mathrm{F}$ Temperature. 64

Experiment 1: Segmented Alcore Honeycomb at Ambient Temperature. 64

Experiment 2: Segmented Alcore Honeycomb at Ambient Temperature. 65

Experiment 3: Segmented Alcore Honeycomb at Ambient Temperature. 65

Experiment 1: Segmented Hexcel Honeycomb at $+165^{\circ} \mathrm{F}$ Temperature. $\quad 66$

Experiment 2: Segmented Hexcel Honeycomb at $+165^{\circ} \mathrm{F}$ Temperature. $\quad 66$

Experiment 3: Segmented Hexcel Honeycomb at $+165^{\circ} \mathrm{F}$ Temperature. $\quad 67$

Experiment 1: Segmented Hexcel Honeycomb at Ambient Temperature. 67

Experiment 2: Segmented Hexcel Honeycomb at Ambient Temperature. 68

Experiment 3: Segmented Hexcel Honeycomb at Ambient Temperature. 68

\section{Figures}

1 Aluminum Honeycomb Geometry: (a) principal directions, (b) 9 segmented honeycomb schematic and (c) photograph of segmented honeycomb.

2 Top View of Configuration for Segmented Honeycomb Experiments. 10

3 Drop Table Underside Configuration for Segmented Honeycomb 11 Experiments.

4 Schematic Representation of the Force Reconstruction Technique, Sum 12 of Weight Accelerations using a Calibrated Force (SWAT-CAL).

5 Four Acceleration Responses Measured on the Drop Table for an Amplitude of $1217 \mathrm{~g}$ with a $2.26 \mathrm{~ms}$ Duration, at 10\% Amplitude.

6 Two Load Cell Responses Measured on the Reaction Mass for an Amplitude of $1217 \mathrm{~g}$ with a $2.26 \mathrm{~ms}$ Duration, at $10 \%$ Amplitude.

7 Load Cell Force Measurement for Three Different Honeycomb Strengths (Bandwidth of DC - 10,000 Hz).

8 Load Cell Force Measurement With and WithoutSynthetic Putty 16 (Bandwidth of DC $-10,000 \mathrm{~Hz}$ ).

9 Final Load Cell Configuration With Synthetic Putty. 17

10 Comparison of Crush Velocity and Crush Distance for Alcore 18 Segmented Honeycomb at Ambient Temperature.

11 Averaged Crush Characteristics Comparison, DC-2000 Hz Bandwidth 25 (Segmented Alcore Honeycomb at $+165^{\circ} \mathrm{F}$ Temperature).

12 Averaged Crush Characteristics Comparison, DC-2000 Hz Bandwidth 26 (Segmented Alcore Honeycomb at Ambient Temperature).

13 Averaged Crush Characteristics Comparison, DC-2000 Hz Bandwidth 27 (Segmented Hexcel Honeycomb at $+165^{\circ} \mathrm{F}$ Temperature).

14 Averaged Crush Characteristics Comparison, DC-2000 Hz Bandwidth 28 (Segmented Hexcel Honeycomb at Ambient Temperature). 


\section{Figures (cont.)}

15 Segmented Alcore Honeycomb, Averaged Crush Characteristics 29 Comparison, DC-2000 Hz Bandwidth.

16 Segmented Hexcel Honeycomb, Averaged Crush Characteristics 30 Comparison, DC-2000 Hz Bandwidth.

17 Segmented Alcore Honeycomb Averaged Crush Characteristics 31 Comparison as a Function of Velocity, DC-2000 Hz Bandwidth.

18 Segmented Hexcel Honeycomb Averaged Crush Characteristics 32 Comparison as a Function of Velocity, DC- $2000 \mathrm{~Hz}$ Bandwidth.

\section{Tables}

I Comparison of Two Independent Force Measurement Techniques for an Impact Machine Pulse of $1217 \mathrm{~g}$ with $\mathrm{a}_{1} 2.26 \mathrm{~ms}$ Duration, Measured at $10 \%$ Amplitude.

II Impact Velocity, Crush Distance, and Mean Crush Stress for Thirteen Segmented Honeycomb Experiments.

III Data Analysis Description for Tables IV-VIII. 19

IV SWAT Derived and Load Cell Stress Averaged for Multiple 20 Experiments.

V SWAT Derived Stress Averaged for Multiple Experiments. 20

VI Load Cell Stress Averaged for Multiple Experiments. 21

VII Comparison of SWAT Derived and Load Cell Stress With Peak Stress. 21

VIII Comparison of SWAT Derived and Load Cell Stress Without Peak 21 Stress.

IX Comparison of Averaged Stress Values for Dynamic and Quasi-static 22 Segmented Honeycomb Crush Experiments.

$X \quad$ Comparison of Averaged Stress Values for Dynamic and Confined 22 Moderate Rate Honeycomb Crush Experiments. 


\section{Segmented Aluminum Honeycomb Characteristics in T-Direction, Dynamic Crush Environments}

\section{Introduction}

Sandia National Laboratories (SNL) designs and builds energy absorbing components that are capable of cushioning the impact of a weapon structure in severe impact conditions. The certification of these energy-absorbing components involves both impact experiments and finite element models. The models must be validated so that they provide sufficiently believable results thereby reducing the number of expensive full-scale experiments that are performed. Additionally, the models are used to optimize the experiments by identifying the impact environments.

The honeycomb experiments presented in this report were conducted to aid in the modeling of an energy-absorbing component that uses aluminum honeycomb. Thirteen, segmented aluminum honeycomb samples (5 in. and 1.5 in. nominal diameter and height, respectively) have been crushed in the SNL Mechanical Shock Laboratory; an impact machine drop table provides the crush weight of $175 \mathrm{lb}$. This report summarizes impact experiments with a unique segmented honeycomb geometry manufactured by Alcore* and Hexcel ${ }^{*}$, both with a nominal bulk density of 38.0 pcf. All experiments were conducted at an impact velocity of $\approx 50 \mathrm{fps}$ and crushed the honeycomb in the highest strength orientation, T-direction. Two independent measurements of the crush force were made with a load cell and an acceleration derived force. This report contains the details of the load cell calibration and modal analysis, characterization of the drop table with the Sum of Weighted Accelerations Technique with a Calibrated Force (SWAT-CAL), normalized stress-strain curves, pictures of the crushed samples, the raw acceleration data and load cell data for all thirteen experiments. The two independent measurements of the honeycomb characteristics, load cell and SWAT-derived stress, agree well and have a maximum percentage difference of $8.2 \%$ that is less than the $11 \%$ uncertainty estimated for these data. The honeycomb characteristics are presented as stress-strain plots, and all results have been examined for validity. Since the cross-sectional area of the segmented honeycomb did not change during the crush, these are the best dynamic data available for honeycomb undergoing crush in an impact environment. The consistency of the dynamic enhancement suggests that the dynamic performance of the segmented honeycomb may be inferred from static screening tests. *Reference to a commercial product implies no endorsement by SNL or the Department of Energy or lack of suitable substitute. 


\section{Experimental Configuration}

Aluminum honeycomb has three principal directions due to its composition of corrugated and flat aluminum sheets. These directions, $T$, the strongest, $\mathrm{L}$, the intermediate strength, and $W$, the weakest are shown schematically in Figure $1 a$. The honeycomb tested here is a configuration of $90^{\circ}$ pie segments bonded together as shown in Figure $1 b$. Generally, the L-direction is radially-oriented, and the weak W-direction is circumferentially-oriented. Hence, this unique honeycomb geometry is approximately an axisymmetric material about the Taxis. The general experimental configuration for thirteen segmented aluminum honeycomb crush experiments is shown in Figures 2 and 3. The honeycomb sample was placed on the load cell in the specified T-orientation. Accelerometers were mounted on the drop table and the reaction mass to obtain data for calculation of stress-strain characteristics, and the GHI, Inc. optical device measured impact velocity.

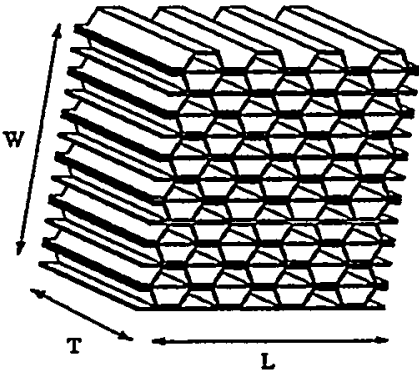

(a)

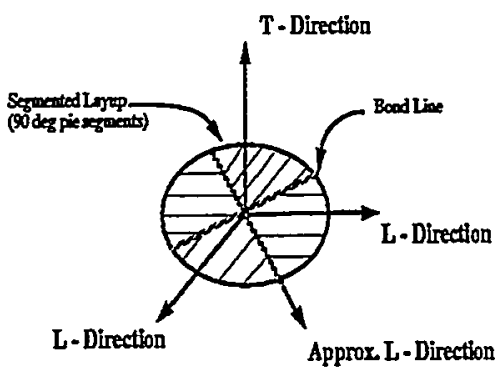

(b)

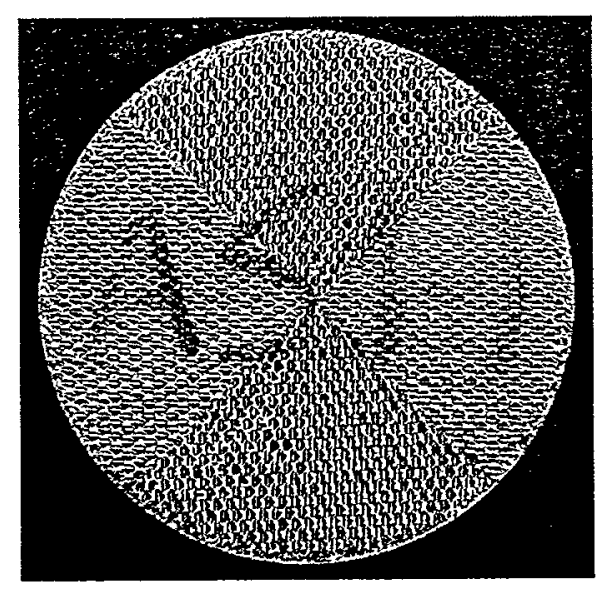

(c)

Figure 1. Aluminum Honeycomb Geometry: (a) principal directions, (b) segmented honeycomb schematic, and (c) photograph of segmented honeycomb. 


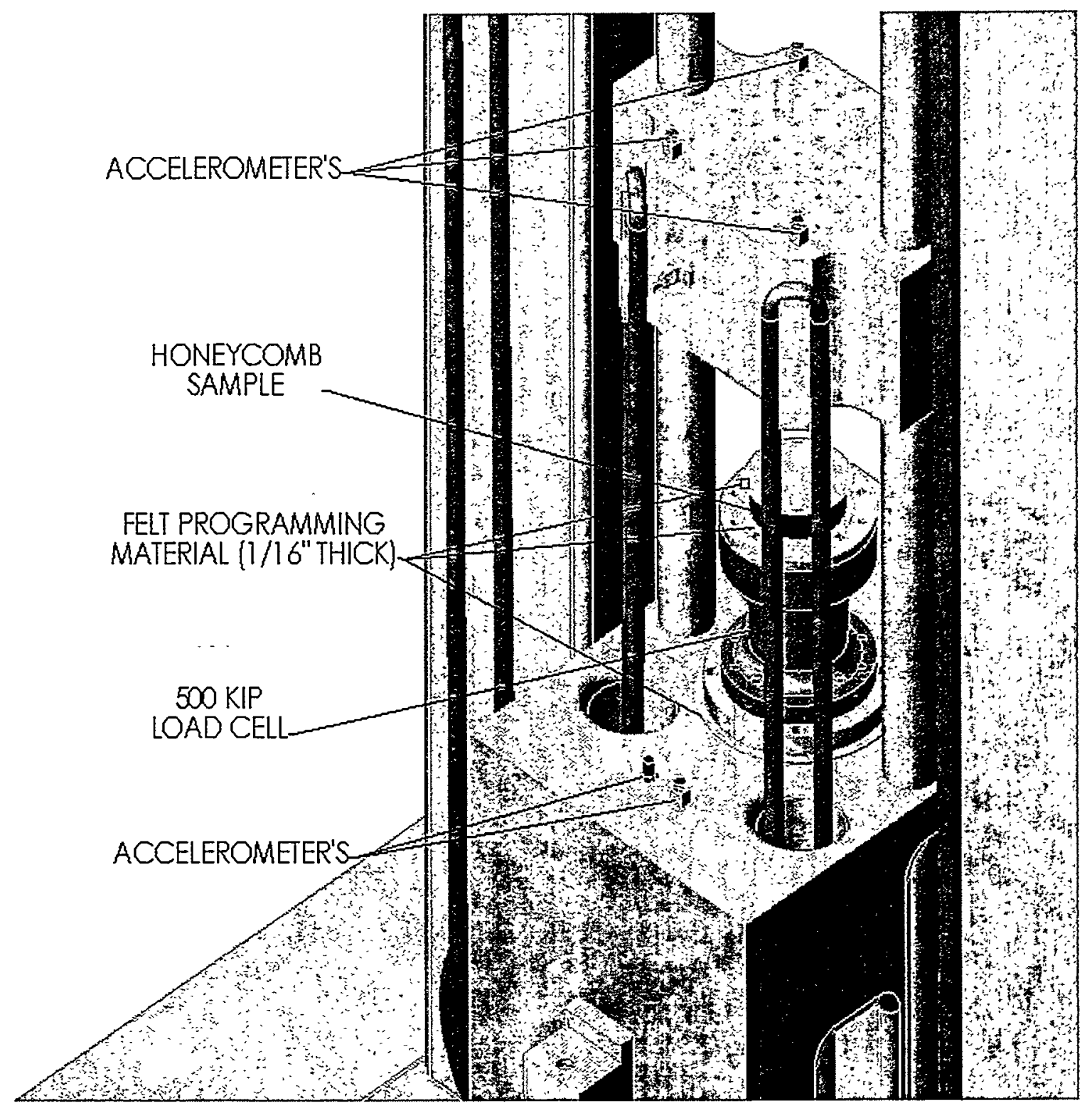

\section{Figure 2: Top View of Configuration for Segmented Honeycomb Experiments.}

Two independent measurement techniques were used to derive the segmented honeycomb crush characteristics. The first measurement uses a Type 6061 Aluminum load cell that had been designed and used for another program at SNL. The load cell has two, four-arm, strain gage bridges and was calibrated with static force in the SNL Structural Mechanics Lab that is certified as a Secondary Force Calibration Laboratory. The results of the calibration and a picture of the calibration configuration are shown in Appendix A. One bridge has a $+5 \%$ deviation below $100,000 \mathrm{lb}$, and the other bridge has a $-4 \%$ deviation below $100,000 \mathrm{lb}$. Both bridges approach $0 \%$ deviation above $200,000 \mathrm{lb}$. 
Consequently, the two bridge outputs were examined individually for every experiment and then averaged together to obtain an approximately $0 \%$ deviation curve over the entire force range.

The dynamic characteristics of the load cell were also examined. First a model of the load cell was created in Solid Works (Version 2000) with both ends of the load cell fixed. A modal analysis was performed by a Cosmos Works (Version 5.0) high quality finite element analysis with 20785 elements and 33384 nodes. The first ten elastic mode shapes and frequencies are shown in Appendix A. The first modal frequency is $8390 \mathrm{~Hz}$ and is over four times the final bandwidth for the segmented honeycomb crush characteristics, DC-2000 Hz. This result indicates that the load cell elastic response does not distort the dynamic force measurements and was crucial to the interpretation of the measurements made

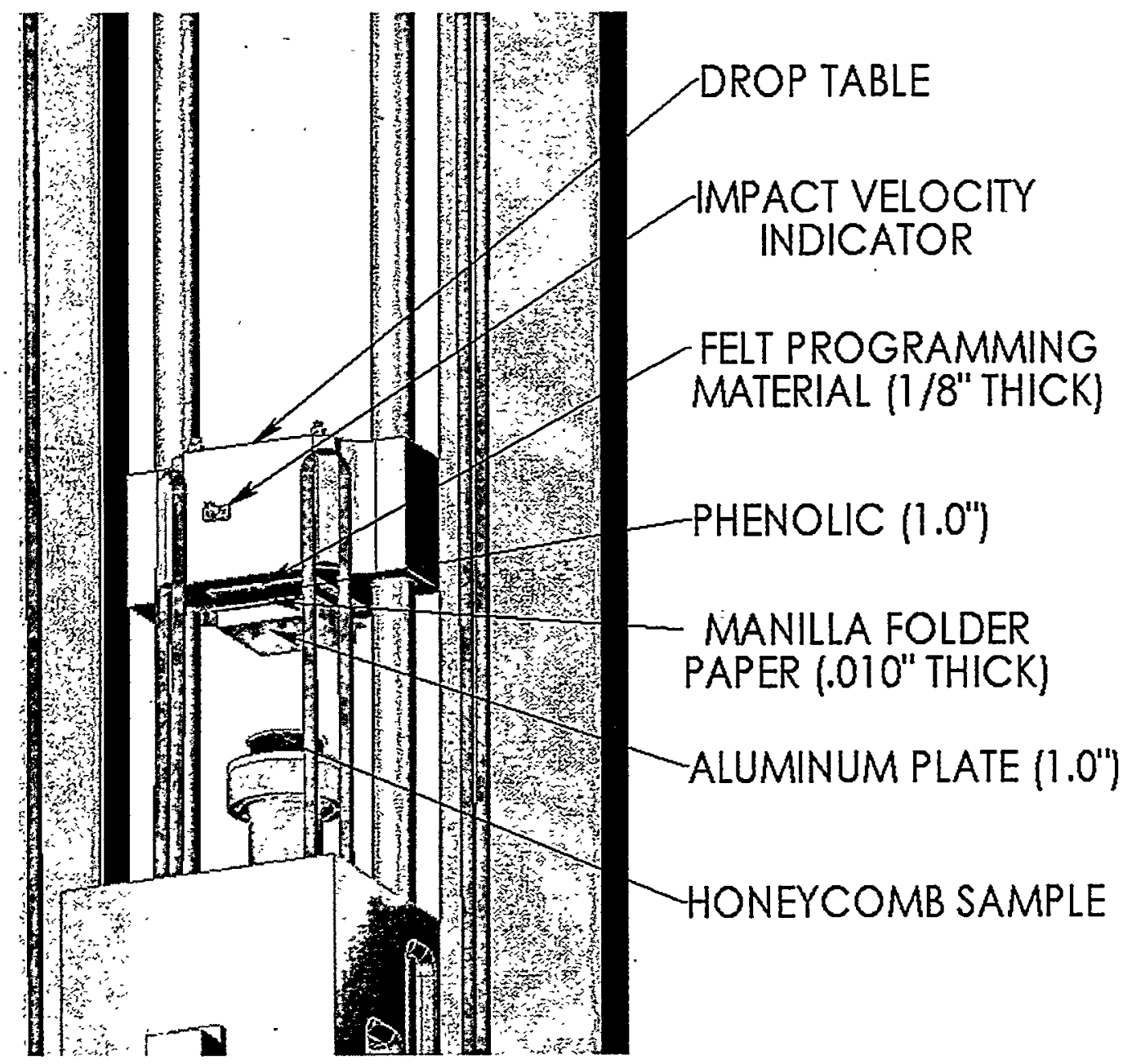

Figure 3: Drop Table Underside Configuration for Segmented Honeycomb Experiments. 
during dynamic honeycomb crush experiments. Two other load cell boundary conditions were examined, one end fixed and one free and both ends free. The modal frequencies and shapes did not change significantly with these different boundary conditions. A final modal analysis with the bottom fixed and the 175 $\mathrm{lb}$ load of the carriage weight on top of the load cell showed significantly lower modal frequencies, but none of these frequencies are apparent in the data.

The second measurement technique uses four accelerometers mounted on the extreme four corners of the drop table. The accelerometers are the ENDEVCO 7270AM6-20K developed at SNL [1]. The individual measured accelerometer responses are multiplied by a scalar and added together. The scalar weights are calculated using a technique, the Sum of Weighted Accelerations Technique with a Calibrated Force (SWAT-CAL), also developed at SNL [2]. This technique is described elsewhere [2] and is shown schematically in Figure 4. The resulting acceleration sum is the drop table's acceleration of the center of mass and is multiplied by the mass of the table, $175 \mathrm{lb}$, to obtain the crush force via Newton's Second Law.

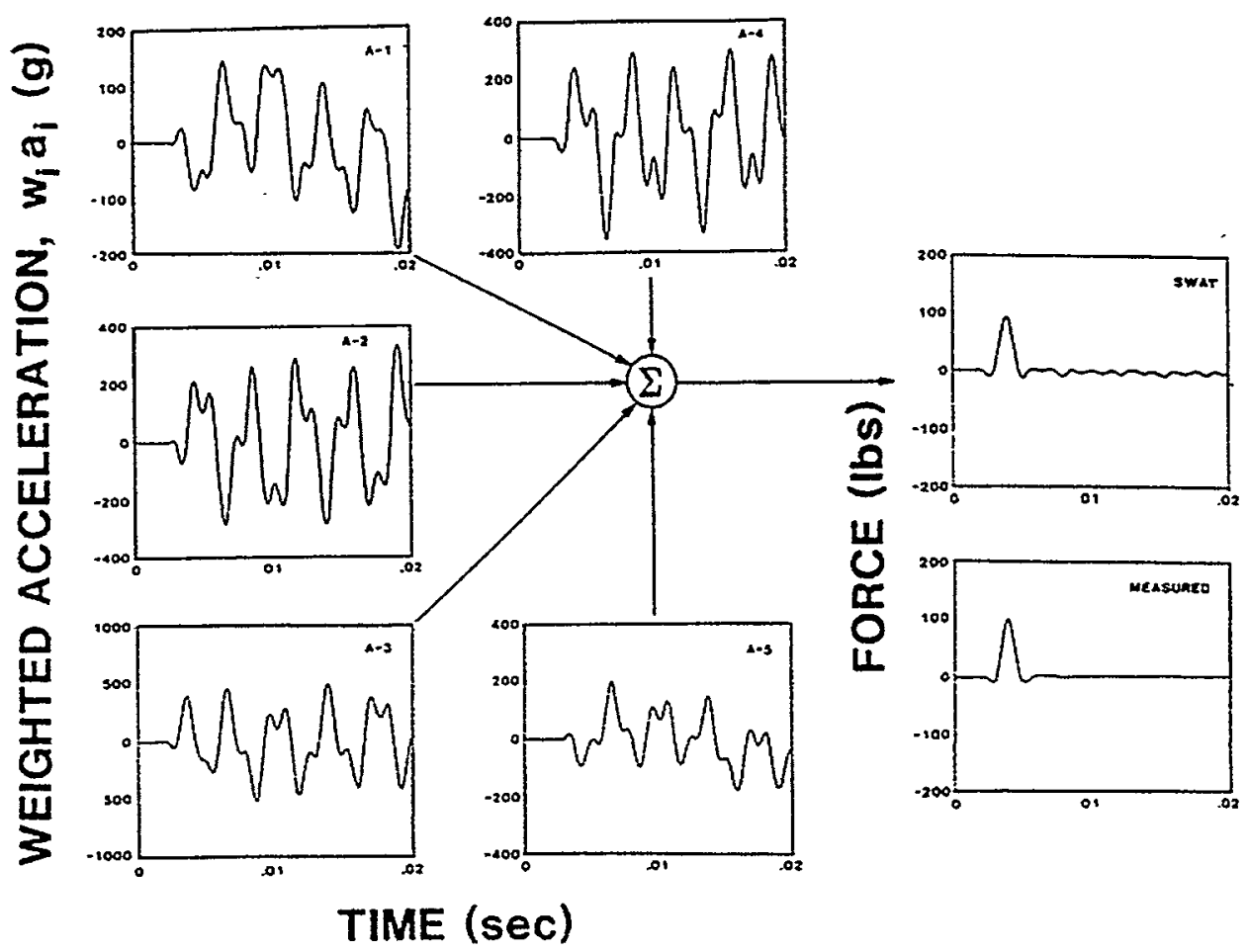

Figure 4: Schematic Representation of the Force Reconstruction Technique, Sum of Weight $\underline{\text { Accelerations using a }}$ Calibrated Force (SWAT-CAL). 
A comparison of these two force measurement techniques was conducted with a long duration impact pulse created with felt placed on top of the load cell. The impact pulse parameters are $1217 \mathrm{~g}$ with a duration measured at $10 \%$ amplitude of $2.26 \mathrm{~ms}$. The velocity change for this pulse is $55 \mathrm{fps}$ and is close to the impact velocity used for the actual crush experiments. The purpose of the long duration pulse is to obtain the most rigid body response possible over the regime of interest from the load cell, the drop table, and the associated impact machine structure for evaluation of the two techniques. The acceleration responses for the long duration pulse are shown in Figure 5. The four peak accelerations agree within $5 \%$. The two load cell responses are shown in Figure 6 . The two peak forces agree within $3 \%$. The acceleration responses are multiplied by their individual scalar weights computed with SWAT-CAL and added together as shown in Figure 4. This sum is the acceleration of the drop table center of mass. The drop table force is the product of the acceleration of the center of mass and the drop table weight (Newton's Second Law). The two load cell measurements were averaged as described previously. The results of this comparison are shown in Table I where a difference of $2.3 \%$ between the two independent force measurements is reported. The bandwidth for these data is DC-5000 Hz. This comparison provides confidence in the performance of the two force measurement techniques during shorter duration pulses created by the honeycomb experiments.

\section{Table I: Comparison of Two Independent Force Measurement Techniques for an Impact Machine Pulse of $1217 \mathrm{~g}$ with a $2.26 \mathrm{~ms}$ Duration, Measured at 10\% Amplitude.}

\begin{tabular}{|c|c|c|}
\hline $\begin{array}{c}\text { SWAT-CAL } \\
\text { Derived Force }\end{array}$ & $\begin{array}{c}\text { Load Cell } \\
\text { Force }\end{array}$ & $\begin{array}{c}\text { Percent } \\
\text { Difference }\end{array}$ \\
\hline $212,975 \mathrm{lb}$ & $208,098 \mathrm{lb}$ & 2.3 \\
\hline
\end{tabular}

In order to obtain the correct honeycomb crush velocity and displacement, the motion of the impact machine reaction mass is measured. Figure 2 shows the location of the two accelerometers, ENDEVCO 7270AM6-6K and ENDEVCO 2262-1000 on the reaction mass. These two accelerations were examined individually for every experiment and then averaged together. The averaged reaction mass acceleration is integrated to obtain the reaction mass velocity. The honeycomb crush velocity is the difference between the SWAT-CAL derived velocity and the reaction mass velocity. The honeycomb crush distance is the integral of the honeycomb crush velocity and is compared to the physical measurements of the segmented honeycomb sample before and after the crush. 


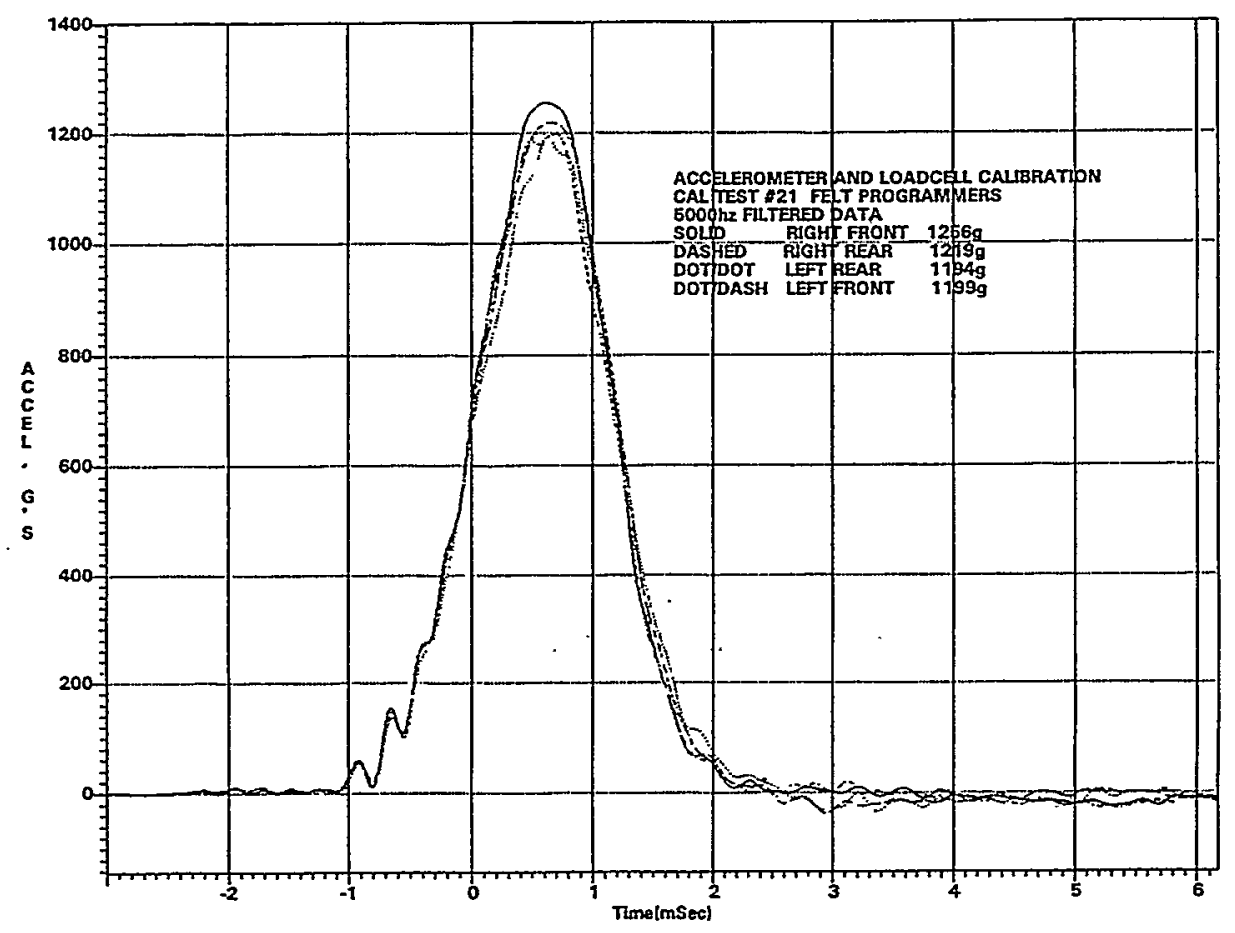

Figure 5 : Four Acceleration Responses Measured on the Drop Table for an Amplitude of $1217 \mathrm{~g}$ with a $2.26 \mathrm{~ms}$ Duration, at $10 \%$ Amplitude.

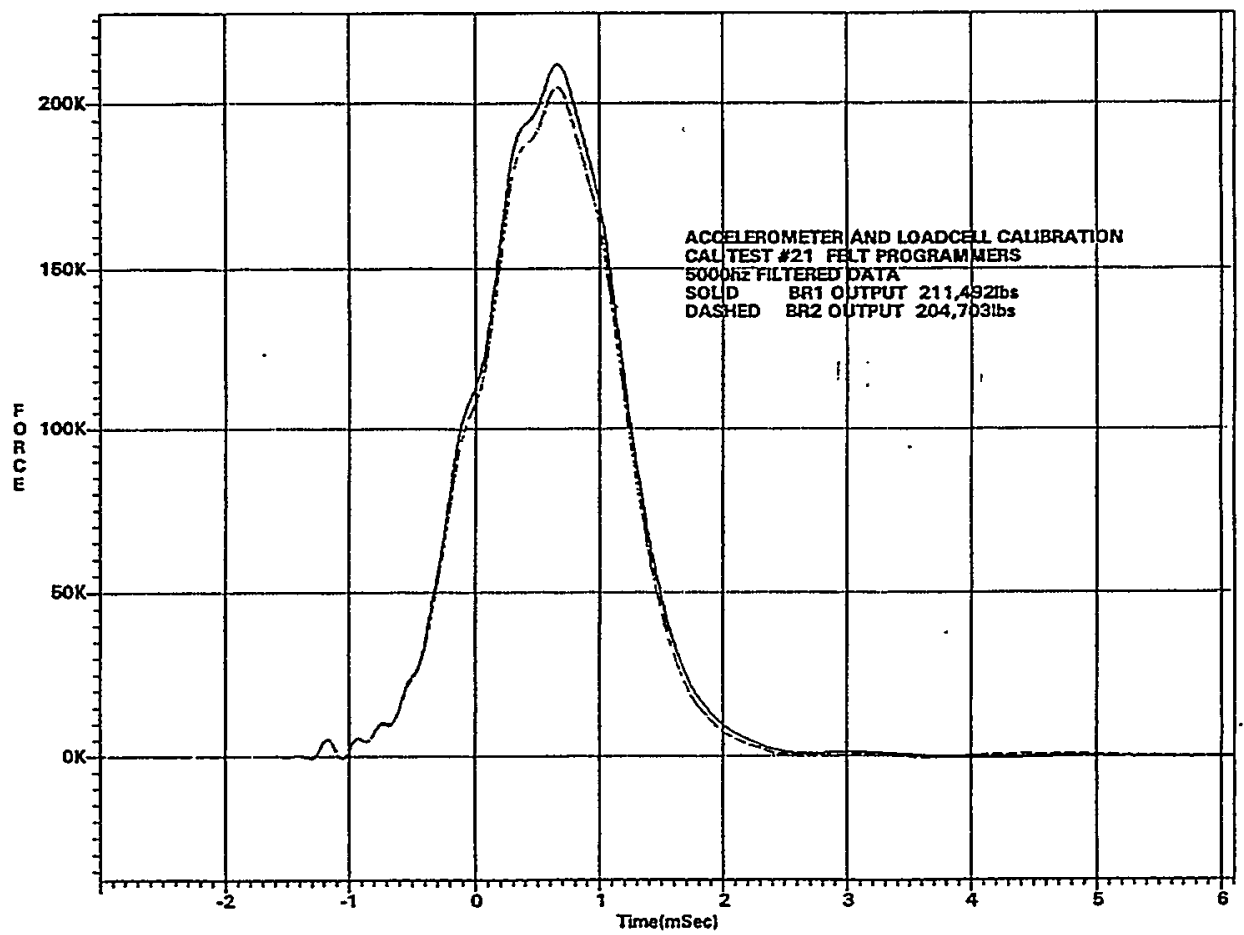

Figure 6: Two Load Cell Responses Measured on the Reaction Mass for an Amplitude of $1217 \mathrm{~g}$ with a $2.26 \mathrm{~ms}$ Duration, at 10\% Amplitude. 
The drop table acceleration and the load cell measurements showed significant frequency content during initial experiments to evaluate the response during actual high strength honeycomb crush (not-segmented). A drop table impact machine is not normally used in the configuration shown in Figures 2 and 3 , and the short rise-time pulse created by the honeycomb crush excited considerable structural response at about $2500 \mathrm{~Hz}$. Consequently, great care was taken to eliminate as much of the impact machine's structural response as possible from the measurements. The solution for the drop table acceleration measurements is to create an impedance mismatch between the aluminum plate and drop table with the addition of the felt, phenolic, and paper shown in Figure 3. Fast Fourier transforms (fft's) of the drop table acceleration, load cell force, and reaction mass acceleration data showed that the reaction mass and associated hydraulic suspension are the source of the unwanted frequency content at $2500 \mathrm{~Hz}$. The ratio of the reaction mass to the drop table mass is seventeen, so it is not surprising that the reaction mass structural response is so dominate. Since the load cell is directly connected to the reaction mass and associated hydraulic suspension, it is more difficult to eliminate the unwanted frequency content. Figure 7 shows the load cell force measurement with a bandwidth of DC - 10,000 $\mathrm{Hz}$ for three different strengths of honeycomb and the resultant variations in the unwanted frequency content. The lower strength honeycomb crush does not have as sharp a rise-time, so the frequency content riding on the top of the pulse is lower and its magnitude is a smaller percentage of the mean force value. In comparison, the highest strength honeycomb crush has a very sharp a rise-time, so the frequency content riding on the top of the pulse is higher and its magnitude is a larger percentage of the mean force value. The addition of synthetic putty on the outside of the load cell decreases the structural response magnitude transmitted to the load cell by about $30 \%$ as shown in Figure 8 (bandwidth of DC -10,000 Hz). Figure 9 shows the final load cell configuration with the synthetic putty. The bandwidth of these data is DC $-10,000 \mathrm{~Hz}$, and the bandwidth of the honeycomb characteristics is DC $-2000 \mathrm{~Hz}$. The honeycomb characteristics shown in the next section have much less of the unwanted 2500 $\mathrm{Hz}$ frequency because they have been filtered with a low-pass, digital filter that has a cutoff frequency of $2000 \mathrm{~Hz}$. Additionally, the SWAT-CAL technique attenuates the unwanted $2500 \mathrm{~Hz}$ frequency with its weighted acceleration sum.

The impact machine has a maximum impact velocity of $80 \mathrm{fps}$ and the highest possible impact velocity would give the most relevant honeycomb characteristics for its intended use. However, when the honeycomb was crushed with impact velocities of $\approx 60 \mathrm{fps}$, the weights for the SWAT-CAL differed significantly from the weights calculated from data with $\approx 50 \mathrm{fps}$ impact velocity. This change indicates that impact machine response is non-linear at the higher velocity. Consequently, the $\approx 50$ fps impact velocity was chosen for the segmented honeycomb experiments. 


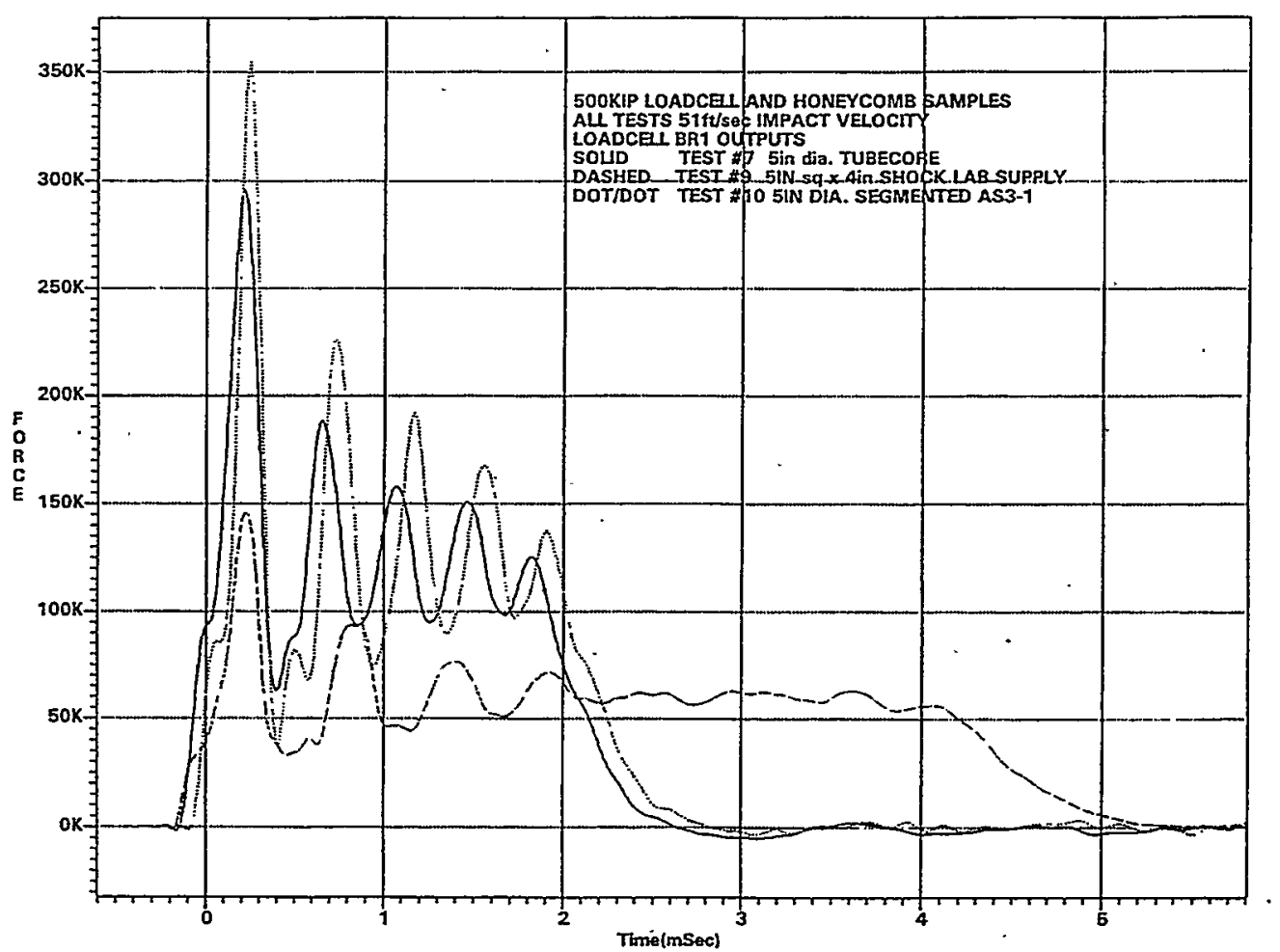

Figure 7: Load Cell Force Measurement for Three Different Honeycomb Strengths (Bandwidth of DC - 10,000 Hz).

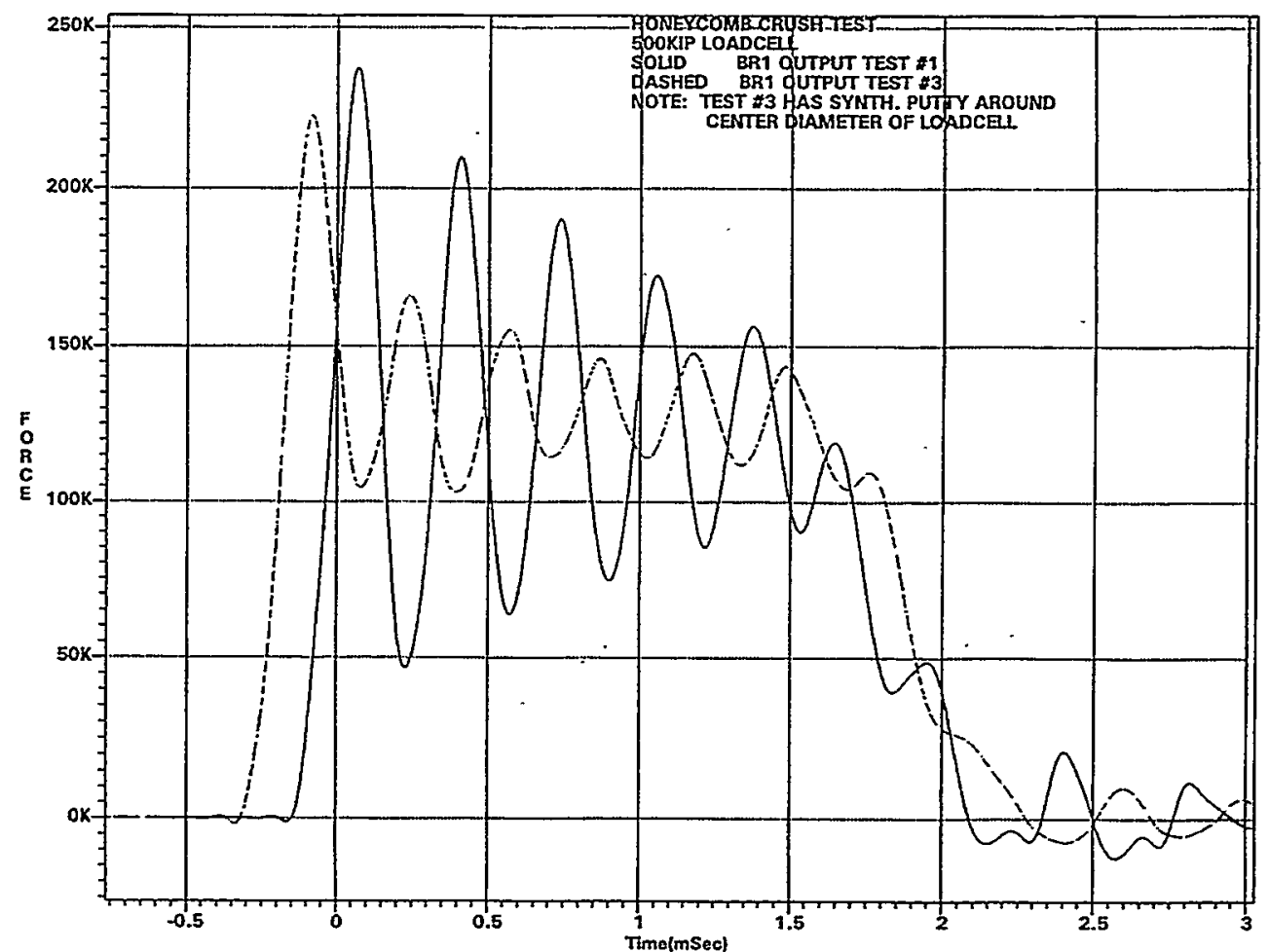

Figure 8: Load Cell Force Measurement With and Without Synthetic Putty (Bandwidth of DC $-10,000 \mathrm{~Hz}$ ). 

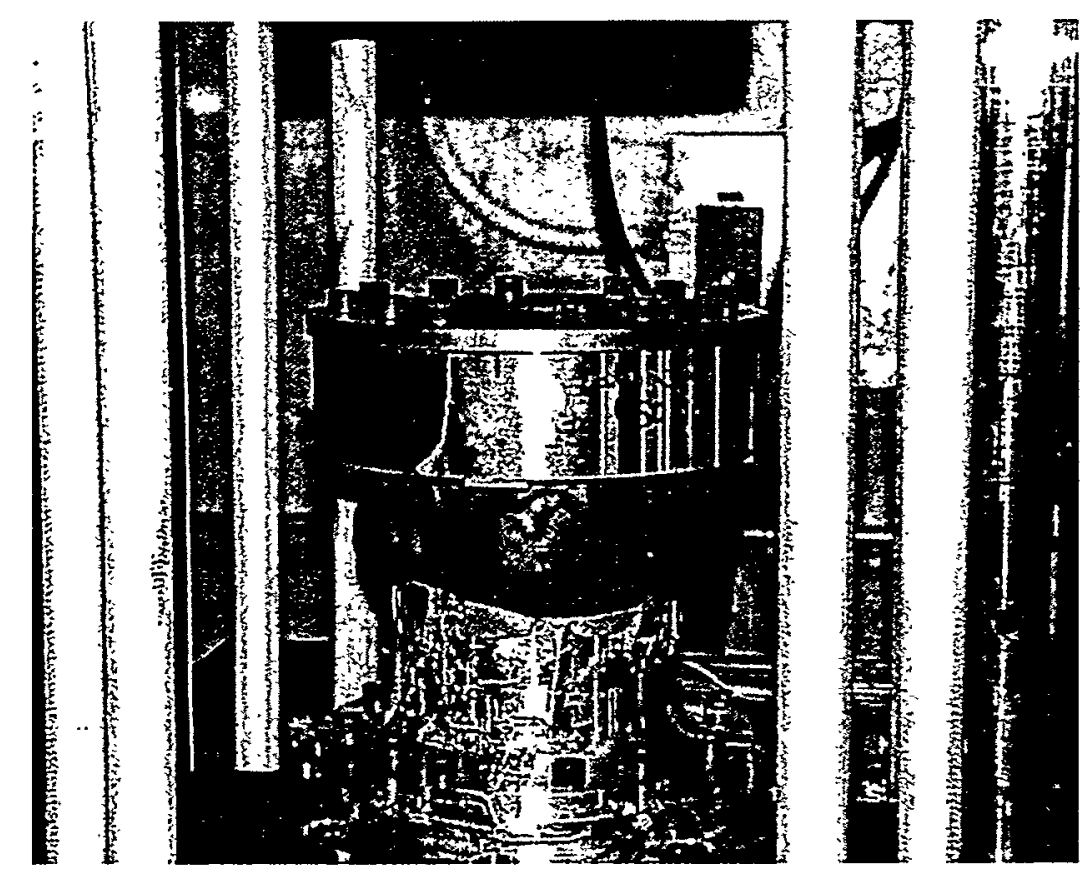

Figure 9 Final Load Cell Configuration With Synthetic Putty.

\section{Experimental Results}

Below is Table II with the impact velocity and crush distance for the thirteen segmented honeycomb crush experiments. The impact velocity was measured as close to drop table impact as possible with an optical device made by GHI, Inc. The crush distance values are the difference between the pre-crush sample height, nominally $1.5 \mathrm{in}$. and the post-crush sample height. The post-crush sample height is the average of three measurements of the crushed sample height with the felt removed. It was concluded from a visual inspection of each sample post-test that the diameter did not change during the sample crush. This could not be verified with physical measurements because the epoxy coating around the circumference cracked during the experiments. The irregular cracked epoxy prevented meaningful diameter measurements post-test. A visual comparison of the crushed sample diameter with the felt diameter indicated that the sample diameter did not change from the pre-test value. The mean crush stress value for each experiment is also shown in Table II, with and without the peak stress included. The SWAT-CAL derived stress and the load cell derived stress were averaged for these values. All stress values are rounded to three significant figures and have an uncertainty of $\pm 11 \%$. Two mean crush stress values are provided because the samples did not have maximum crush (lockup) at the impact velocity for these experiments. The mean crush stress with the peak included may be considered the crush stress for the first half of the crush strain before lockup that occurs at about 1 in. crush for these samples. The mean crush stress without the peak included may be considered the crush stress for the second half of the crush strain before lockup. 
Table II: Impact Velocity, Crush Distance, and Mean Crush Stress for Thirteen Segmented Honeycomb Experiments

( $\pm 11 \%$ Uncertainty).

\begin{tabular}{|c|c|c|c|c|c|}
\hline $\begin{array}{l}\text { Experiment Set/ } \\
\text { Temperature }\end{array}$ & No. & $\begin{array}{l}\text { Impact } \\
\text { Velocity } \\
\text { (fps) }\end{array}$ & $\begin{array}{c}\text { Crush } \\
\text { Distance } \\
\text { (in.) }\end{array}$ & $\begin{array}{c}\text { With Peak } \\
\text { Stress } \\
\text { (psi) }\end{array}$ & $\begin{array}{l}\text { Without } \\
\text { Peak Stress } \\
\text { (psi) }\end{array}$ \\
\hline \multirow{4}{*}{ Alcore at $+165^{\circ} \mathrm{F}$} & 1 & 50.66 & 0.564 & 6480 & 6330 \\
\hline & 2 & 50.99 & 0.561 & 6400 & 6240 \\
\hline & 3 & 51.51 & 0.551 & 6520 & 6410 \\
\hline & 4 & 50.56 & 0.563 & 6490 & 6380 \\
\hline \multirow{3}{*}{$\begin{array}{l}\text { Alcore at } \\
\text { Ambient }\end{array}$} & $\overline{1}$ & 50.91 & 0.483 & 7440 & 7250 \\
\hline & 2 & 50.99 & 0.495 & 7250 & 7060 \\
\hline & 3 & 51.08 & 0.490 & 7410 & 7250 \\
\hline \multirow{3}{*}{ Hexcel at $+165^{\circ} \mathrm{F}$} & $\overline{1}$ & 51.33 & 0.502 & 7240 & 7070 \\
\hline & 2 & 51.16 & 0.514 & 7190 & 7040 \\
\hline & 3 & 51.42 & 0.515 & 7140 & 7010 \\
\hline \multirow{3}{*}{$\begin{array}{l}\text { Hexcel at } \\
\text { Ambient }\end{array}$} & $\overline{1}$ & 52.02 & 0.476 & 7850 & 7700 \\
\hline & 2 & 50.58 & 0.457 & 7730 & 7540 \\
\hline & 3 & 50.74 & 0.458 & 7750 & 7620 \\
\hline
\end{tabular}

The data were analyzed as described in the Experimental Configuration Section above, and the honeycomb characteristics are presented as both stress-time and stress-strain plots. Figure 10 has an example of the intermediate results of crush velocity and crush distance. Appendix B contains comparison of DC- $2000 \mathrm{~Hz}$ and DC-10,000 Hz SWAT-CAL and Load Cell derived stress. Appendix C contains comparison SWAT-CAL and Load Cell derived stress for a DC-2000 Hz bandwidth. Both Appendices $B$ and $C$ have a time-history and a Fourier transform for one experiment from each set in Table II. Appendix $B$ is provided so that the considerable frequency content in the DC-10,000 $\mathrm{Hz}$ bandwidth data is recorded. Appendix $C$ is provided so that the frequency content in the two independent measurements may be compared; the SWAT-CAL derived stress eliminates more of the impact machine frequency content than the Load Cell derived stress. As described in Table III, the two stress vectors in Appendix C were averaged for each experiment. Table II has a mean value calculated for the averaged curve, and Table IV has the average and one standard deviation for the multiple means. Appendix D contains normalized, segmented honeycomb crush characteristics in the form of stress-strain curves. For one technique, the individual and average stress are shown on one plot for one experiment set in Table II. These plots show the excellent repeatability in these data that is also evident in the very small sample standard deviations in Table IV. The mean for the average for each set and technique were calculated and are show in Tables $V$ and VI for the SWAT-CAL derived and the Load Cell derived stresses, 


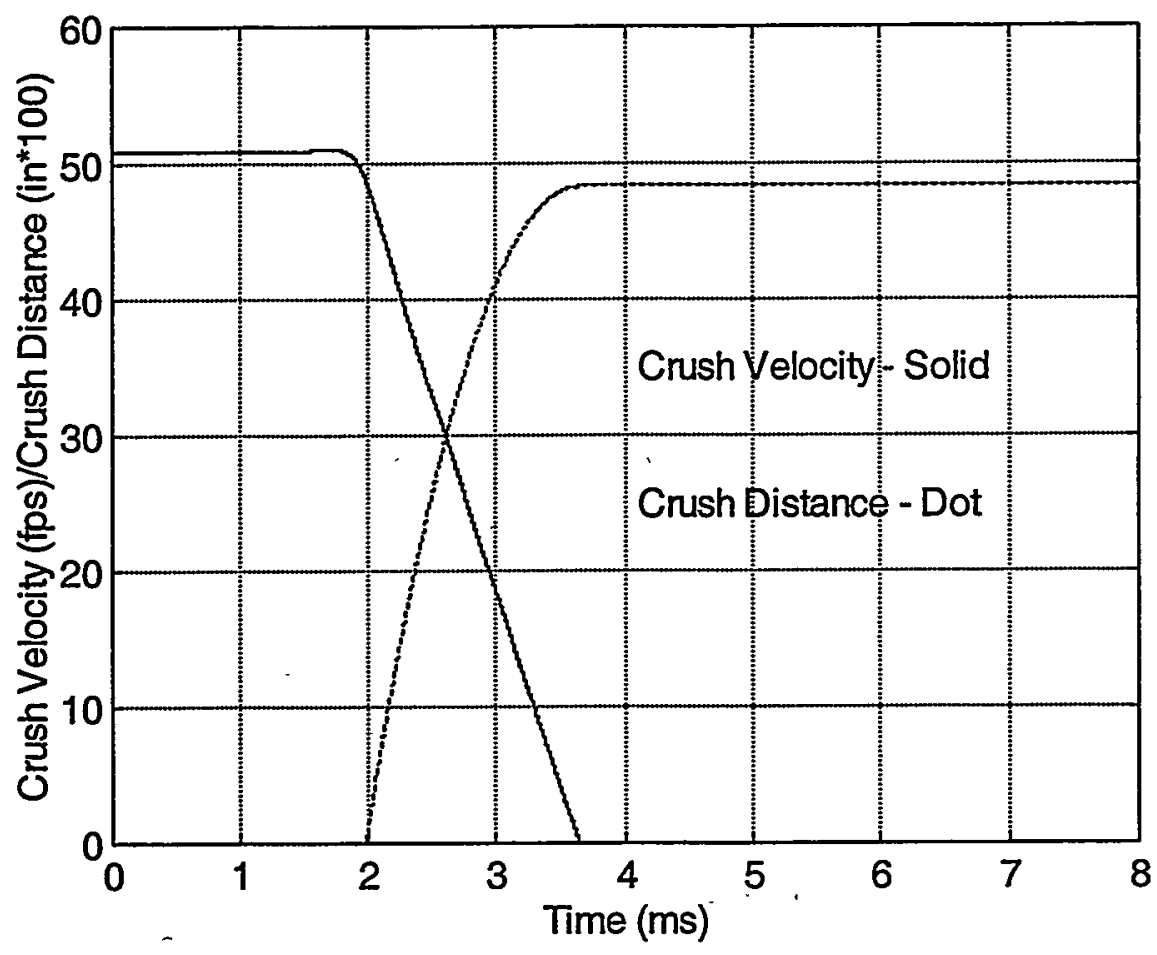

Figure 10: Comparison of Crush Velocity and Crush Distance for Alcore Segmented Honeycomb at Ambient Temperature.

Table III: Data Analysis Description for Tables IV - VIII.

\begin{tabular}{|l|l|}
\hline No. & \multicolumn{1}{|c|}{ Table Description } \\
\hline IV & $\begin{array}{l}\text { SWAT-CAL-Derived Stress and Load Cell Stress averaged for each } \\
\text { experiment. An averaged value of this one stress vector calculated } \\
\text { durring the honeycomb crush with and without the first peak. }\end{array}$ \\
\hline V & $\begin{array}{l}\text { SWAT-CAL-Derived Stress averaged for multiple experiments at each } \\
\text { condition. An averaged value of this one stress vector calculated during } \\
\text { the honeycomb crush with and without the first peak. }\end{array}$ \\
\hline VI & $\begin{array}{l}\text { Load Cell Stress averaged for multiple experiments at each condition. } \\
\text { An averaged value of this one stress vector calculated during the } \\
\text { honeycomb crush with and without the first peak. }\end{array}$ \\
\hline VII & \begin{tabular}{l} 
Averaged Stress values taken from Tables V and VI with the first peak. \\
\hline VIII
\end{tabular} \\
\hline $\begin{array}{l}\text { Averaged Stress values taken from Tables V and VI without the first } \\
\text { peak. }\end{array}$ \\
\hline
\end{tabular}


respectively. Tables V and VI provided the values for Tables VII and VIII that show a maximum difference between the two techniques of $8.2 \%$. This maximum difference is less than the estimated uncertainty of $\pm 11 \%$. Finally, the two stress values in Table IV were averaged and compared to quasi-static data in Table IX $[3,4]$ and moderate rate data in Table X $[5,6,7]$ reported by Wei-Yang Lu.

These results show dynamic enhancement, or increase in crush strength, of from $+15 \%$ to $+19 \%$ for Alcore and from $+7 \%$ to $+12 \%$ for Hexcel. Summary plots for each experiment set are provided in the form of averaged stress-strain curves in Figures 11-16 and averaged stress as a function of crush velocity in Figures 1718. Appendix $\mathrm{E}$ contains a picture of each crushed segmented honeycomb sample except for Experiment 4 for Alcore at $+165^{\circ} \mathrm{F}$. The honeycomb sample for Experiment 4 was impacted twice to verify the experimental configuration during initial crushes, so it is not shown.

\section{Table IV: SWAT-CAL Derived and Load Cell Stress Averaged for Multiple Experiments* $(\mathbf{+ 1 1 \%}$ Uncertainty).}

\begin{tabular}{|c|c|c|c|}
\hline $\begin{array}{l}\text { Experiment Set } / \\
\text { Temperature }\end{array}$ & $\begin{array}{c}\text { With Peak } \\
\text { Stress (psi) }\end{array}$ & $\begin{array}{c}\text { Without Peak } \\
\text { Stress (psi) }\end{array}$ & $\begin{array}{c}\text { Percent } \\
\text { Difference }\end{array}$ \\
\hline Alcore at $+165^{\circ} \mathrm{F}$ & $6,470 \pm 50$ & $6,340 \pm 70$ & 2.1 \\
\hline Alcore at Ambient & $7,370 \pm 100$ & $7,190 \pm 110$ & 2.5 \\
\hline Hexcel at $+165^{\circ} \mathrm{F}$ & $7,190 \pm 50$ & $7,040 \pm 30$ & 2.1 \\
\hline Hexcel at Ambient & $7,780 \pm 60$ & $7620 \pm 80$ & 2.0 \\
\hline
\end{tabular}

*All tests at nominal $50 \mathrm{fps}$ Impact Velocity

**Plus or minus one sample standard deviation

\section{Table V: SWAT-CAL Derived Stress Averaged for Multiple Experiments* ( $\pm 11 \%$ Uncertainty).}

\begin{tabular}{|c|c|c|c|}
\hline $\begin{array}{l}\text { Experiment Set } / \\
\text { Temperature }\end{array}$ & $\begin{array}{c}\text { With Peak } \\
\text { Stress (psi) }\end{array}$ & $\begin{array}{c}\text { Without Peak } \\
\text { Stress (psi) }\end{array}$ & $\begin{array}{c}\text { Percent } \\
\text { Difference }\end{array}$ \\
\hline Alcore at $+165^{\circ} \mathrm{F}$ & 6710 & 6570 & 2.2 \\
\hline Alcore at Ambient & 7600 & 7450 & 1.9 \\
\hline Hexcel at $+165^{\circ} \mathrm{F}$ & 7430 & 7320 & 1.5 \\
\hline Hexcel at Ambient & 8010 & 7890 & 1.5 \\
\hline
\end{tabular}

*All tests at nominal $50 \mathrm{fps}$ Impact Velocity 
Table VI: Load Cell Stress Averaged for Multiple Experiments* ( $\pm 11 \%$ Uncertainty).

\begin{tabular}{|c|c|c|c|}
\hline $\begin{array}{l}\text { Experiment Set } / \\
\text { Temperature }\end{array}$ & $\begin{array}{c}\text { With Peak } \\
\text { Stress (psi) }\end{array}$ & $\begin{array}{c}\text { Without Peak } \\
\text { Stress (psi) }\end{array}$ & $\begin{array}{c}\text { Percent } \\
\text { Difference }\end{array}$ \\
\hline Alcore at $+165^{\circ} \mathrm{F}$ & 6240 & 6080 & 2.6 \\
\hline Alcore at Ambient & 7140 & 6920 & 3.1 \\
\hline Hexcel at $+165^{\circ} \mathrm{F}$ & 6950 & 6760 & 2.8 \\
\hline Hexcel at Ambient & 7540 & 7350 & 2.6 \\
\hline
\end{tabular}

* All tests at nominal $50 \mathrm{fps}$ Impact Velocity

Table VII: Comparison of SWAT-CAL Derived and Load Cell Stress With Peak Stress* $( \pm 11 \%$ Uncertainty).

\begin{tabular}{|l|c|c|c|}
\hline $\begin{array}{l}\text { Experiment Set } / \\
\text { Temperature }\end{array}$ & $\begin{array}{c}\text { Load Cell } \\
\text { (psi) }\end{array}$ & $\begin{array}{c}\text { SWAT-CAL } \\
\text { Derived (psi) }\end{array}$ & $\begin{array}{c}\text { Percent } \\
\text { Difference }\end{array}$ \\
\hline Alcore at $+165^{\circ} \mathrm{F}$ & 6240 & 6710 & 7.5 \\
\hline Alcore at Ambient & 7140 & 7600 & 6.5 \\
\hline Hexcel at $+165^{\circ} \mathrm{F}$ & 6950 & 7430 & 6.8 \\
\hline Hexcel at Ambient & 7540 & 8010 & 6.1 \\
\hline
\end{tabular}

All tests at nominal $50 \mathrm{fps}$ Impact Velocity

Table VIII: Comparison of SWAT-CAL Derived and Load Cell Stress Without Peak Stress* ${ }^{*} \pm 11 \%$ Uncertainty).

\begin{tabular}{|l|c|c|c|}
\hline $\begin{array}{l}\text { Experiment Set } / \\
\text { Temperature }\end{array}$ & $\begin{array}{c}\text { Load Cell } \\
\text { (psi) }\end{array}$ & $\begin{array}{c}\text { SWAT-CAL } \\
\text { Derived (psi) }\end{array}$ & $\begin{array}{c}\text { Percent } \\
\text { Difference }\end{array}$ \\
\hline Alcore at $+165^{\circ} \mathrm{F}$ & 6080 & 6570 & 7.9 \\
\hline Alcore at Ambient & 6920 & 7450 & 7.7 \\
\hline Hexcel at $+165^{\circ} \mathrm{F}$ & 6760 & 7320 & 8.2 \\
\hline Hexcel at Ambient & 7350 & 7890 & 7.3 \\
\hline
\end{tabular}

All tests at nominal $50 \mathrm{fps}$ Impact Velocity 
Table IX: Comparison of Averaged Stress Values for Dynamic and Quasi-static Segmented Honeycomb Crush Experiments $( \pm 11 \%$ Uncertainty).

\begin{tabular}{|l|c|c|c|}
\hline $\begin{array}{c}\text { Manufacturer } \\
\text { and } \\
\text { Temperature }\end{array}$ & $\begin{array}{c}\text { Segmented, } \\
\text { Dynamic } \\
(50 \mathrm{fps})^{* *}\end{array}$ & $\begin{array}{c}\text { Segmented, } \\
\text { Quasi-static } \\
(0.0014 \mathrm{fps})\end{array}$ & $\begin{array}{c}\text { Percent } \\
\text { Difference } \\
\text { (Enhancement) }\end{array}$ \\
\hline Alcore at $+165^{\circ} \mathrm{F}$ & 6400 & ${ }^{*}$ & ${ }^{*}$ \\
\hline Alcore at $-65^{\circ} \mathrm{F}$ & $*$ & ${ }^{*}$ & 19 \\
\hline Alcore at Ambient & 7280 & 6140 & ${ }^{*}$ \\
\hline Hexcel at $+165^{\circ} \mathrm{F}$ & 7110 & $*$ & ${ }^{*}$ \\
\hline Hexcel at $-65^{\circ} \mathrm{F}$ & $*$ & ${ }^{*}$ & 12 \\
\hline Hexcel at Ambient & 7700 & 6850 & \\
\hline
\end{tabular}

* Tests not performed at this date.

** Average of two stress values in Table IV, rounded to three significant figures. *** Quasi-static Tests and Moderate Rate Tests performed by Wei-Yang Lu.

Table X: Comparison of Averaged Stress Values for Dynamic and Confined Moderate Rate Honeycomb Crush Experiments $( \pm 11 \%$ Uncertainty).

\begin{tabular}{|l|c|c|c|}
\hline $\begin{array}{c}\text { Manufacturer } \\
\text { and } \\
\text { Temperature }\end{array}$ & $\begin{array}{c}\text { Segmented, } \\
\text { Dynamic } \\
(50 \mathrm{fps})^{* *}\end{array}$ & $\begin{array}{c}\text { Confined, } \\
\text { Moderate Rate*** } \\
(14 \mathrm{fps})\end{array}$ & $\begin{array}{c}\text { Percent } \\
\text { Difference } \\
\text { (Enhancement) }\end{array}$ \\
\hline Alcore at $+165^{\circ} \mathrm{F}$ & 6400 & 5490 & 17 \\
\hline Alcore at $-65^{\circ} \mathrm{F}$ & $*$ & 7340 & $*$ \\
\hline Alcore at Ambient & 7280 & 6350 & 15 \\
\hline Hexcel at $+165^{\circ} \mathrm{F}$ & 7110 & 6430 & 10 \\
\hline Hexcel at $-65^{\circ} \mathrm{F}$ & $*$ & 8210 & $*$ \\
\hline Hexcel at Ambient & 7700 & 7170 & 7 \\
\hline
\end{tabular}

* Tests not performed at this date.

** Average of two stress values in Table IV, rounded to three significant figures. *** Quasi-static Tests and Moderate Rate Tests performed by Wei-Yang Lu. 


\section{Uncertainty Analysis}

The uncertainty in these measurements and results are attributed to two sources: the uncertainty in the accelerometer/load cell calibrations and the influence of the drop table structural response. The uncertainty in the GHI, Inc. velocity measurement is $0.1 \%$ [8] and is negligible in this analysis. The accelerometer and data acquisition uncertainty is monitored on a continual basis in the SNL Mechanical Shock Laboratory as required by the SNL Specification 9958003 [9]. These requirements include the performance of both the hardware (accelerometers/load cell, amplifiers, digitizers etc.) [9,10] and the software IMPAX that controls the data acquisition system through a computer $[9,11,12]$. The current data acquisition system and software meet these requirements within $\pm 0.5 \%$, and documentation of these results is maintained in the Mechanical.Shock Laboratory. Consequently, the two uncertainties in these data are the uncertainty in the accelerometer/load cell calibration, $\pm 5 \%$ [13] and the influence of the drop table structural response of $10 \%, 95 \%$ confidence level [13]. These two uncertainities are considered random, so they may be combined in an uncertainty analysis with a 95\% confidence level as [14,15]:

$$
w_{T}=\sqrt{w_{s}^{2}+w_{c s r}^{2}}
$$

where: $\quad w_{T}=$ total uncertainty,

$w_{\mathrm{s}}=$ accelerometer $/$ load cell calibration uncertainty $5 \%$, and

1. $\quad \mathrm{W}_{\mathrm{crr}}=$ drop table structural response uncertainty $10 \%$ :

The value of the total uncertainty, $\mathrm{w}_{\mathrm{T}}, \dot{\mathrm{is}} \pm 11 \%$ and is typical for the measurements made in the SNL Mechanical Shock Laboratory.

\section{Conclusions}

Thirteen, segmented aluminum honeycomb samples (5.08 in. diameter and 1.5 in nominal height) have been crushed in the SNL Mechanical Shock Laboratory using an impact machine drop table as the crush weight of $175 \mathrm{lb}$. Experiments were conducted for two honeycomb manufacturers, Alcore* and Hexcel* both with a nominal bulk density of $38.0 \mathrm{pcf}$, and at two temperatures, ambient and $+165^{\circ} \mathrm{F}$. All experiments were conducted at an impact velocity of $\approx 50 \mathrm{fps}$ and crushed the honeycomb in the highest strength orientation, T-direction. Two independent measurements of the crush force were made with a load cell and a SWAT-CAL derived force and have a maximum percentage difference of $8.2 \%$. This percentage difference is less than the uncertainty analysis estimate of $\pm 11 \%$

${ }^{*}$ Reference to a commercial product implies no endorsement by SNL or the Department of Energy or lack of suitable substitute. 
error in these data. The stress strain characteristics calculated for these data have excellent repeatability. These data are strictly valid for material characteristics in the $T$ orientation because the cross-sectional area of the honeycomb did not change during the crush. The data have a consistent dynamic enhancement, or increase in crush strength, of from $+15 \%$ to $+19 \%$ for Alcore and from $+7 \%$ to + $12 \%$ for Hexcel. This consistency suggests that the honeycomb dynamic performance may be inferred from static tests. However, a statistically significant number of experiments should be conducted, if possible.

\section{Acknowledgements}

The authors would like to acknowledge the encouragement, ideas, and enthusiasm of the experimentalists and analysts who have also wrestled with the honeycomb crush characteristics: Barry Boughton, Thomas Carne, Ken Gwinn, Terry Hinnerichs, Darren Hoke, Wei-Yang Lu, John Pott, and Vernon Willan. 


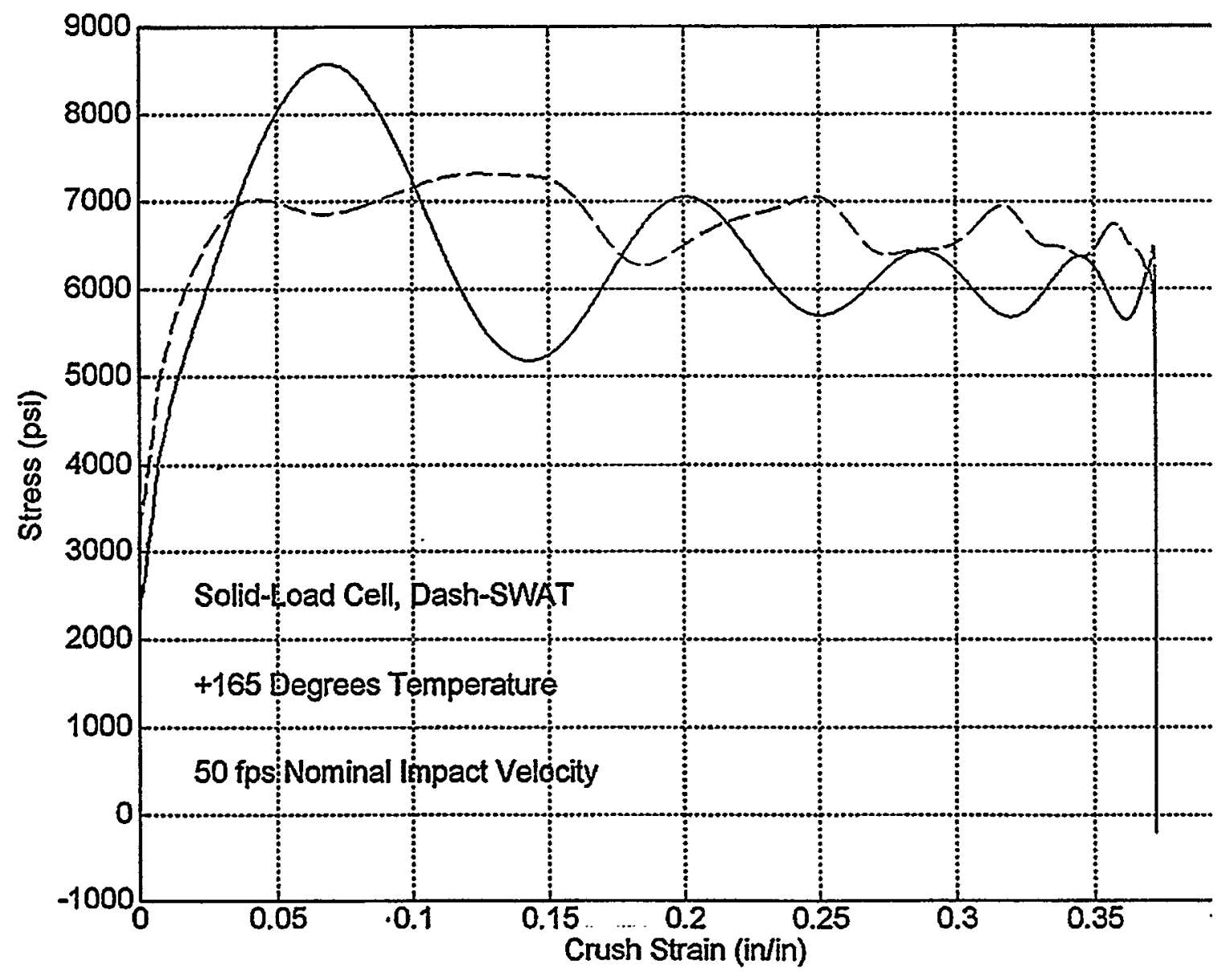

Figure 11

Averaged Crush Characteristics Comparison, DC-2000 Hz Bandwidth (Segmented Alcore Honeycomb at $+165^{\circ} \mathrm{F}$ Temperature). 


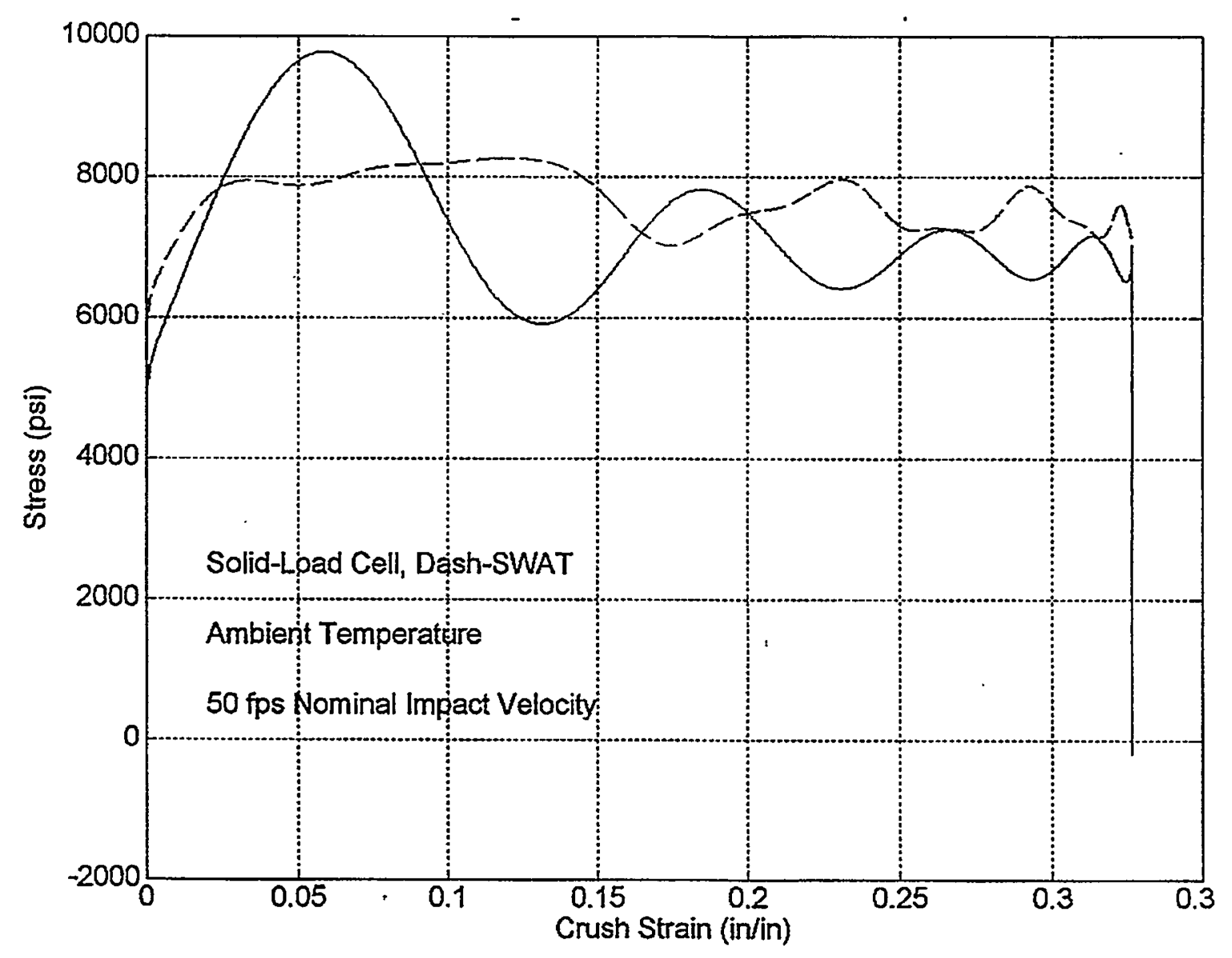

Figure 12

Averaged Crush Characteristics Comparison, DC-2000 Hz Bandwidth (Segmented Alcore Honeycomb at Ambient Temperature). 


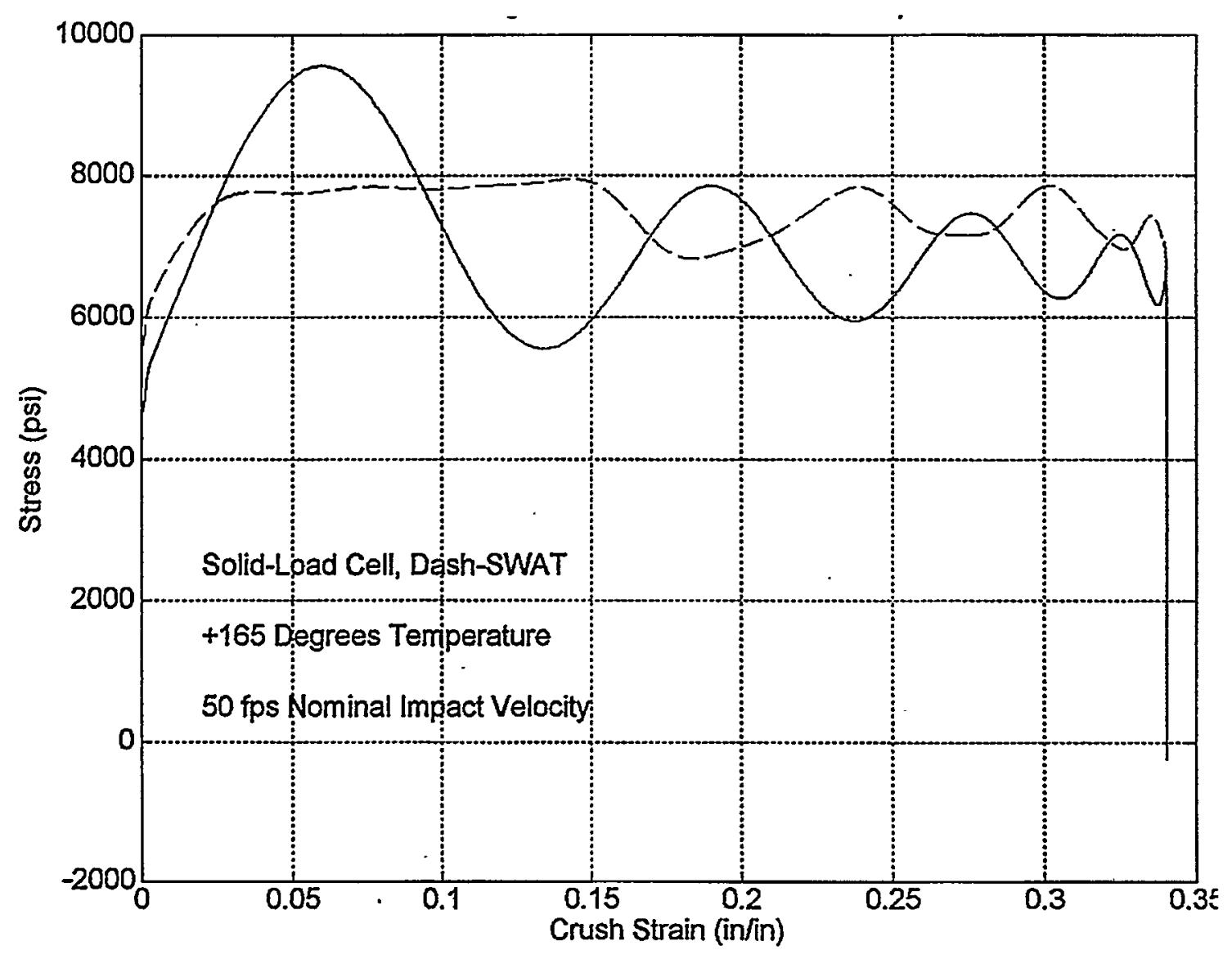

Figure 13

Averaged Crush Characteristics Comparison, DC-2000 Hz Bandwidth (Segmented Hexcel Honeycomb at $+165^{\circ} \mathrm{F}$ Temperature). 


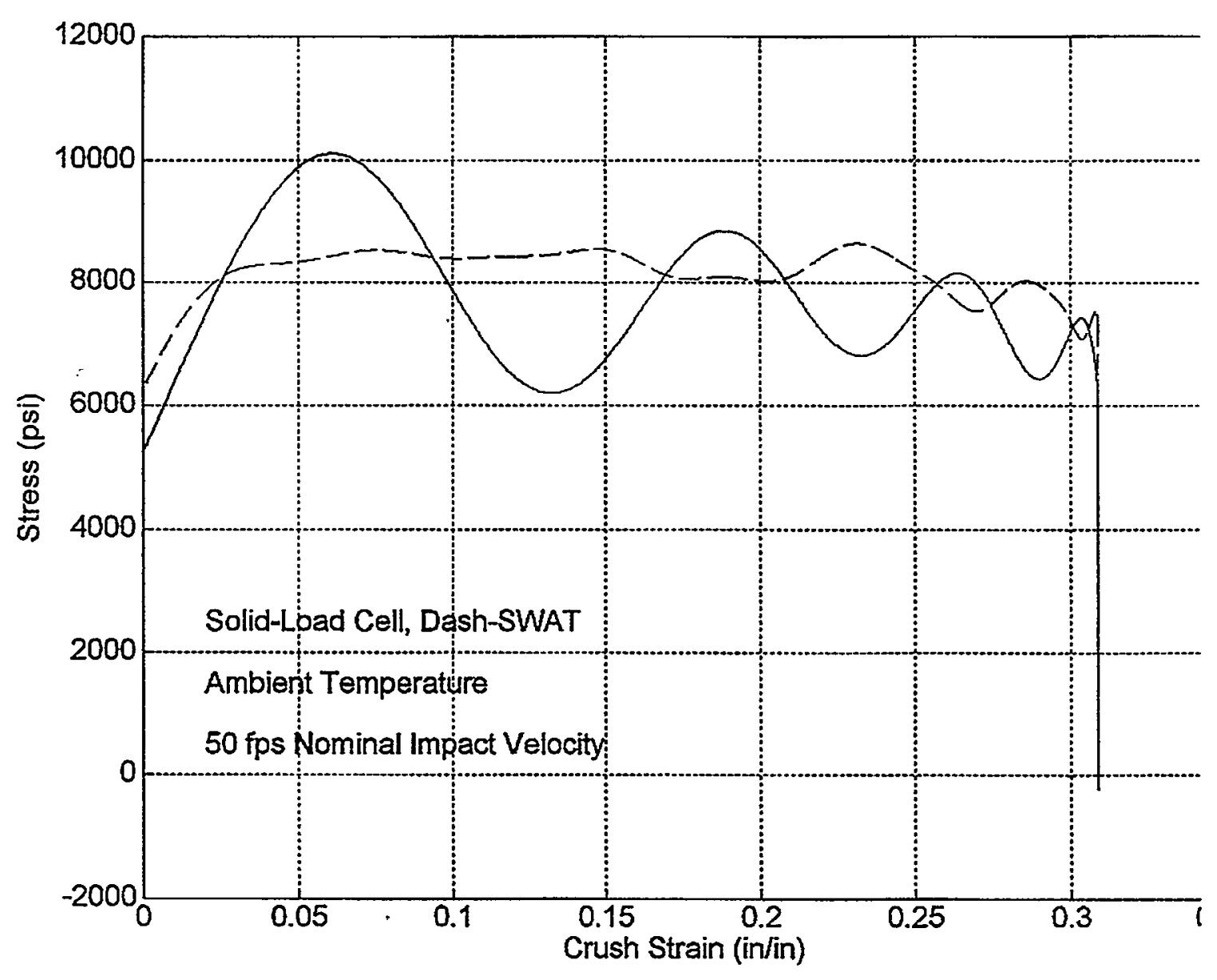

Figure 14

Averaged Crush Characteristics Comparison, DC-2000 Hz Bandwidth (Segmented Hexcel Honeycomb at Ambient Temperature). 


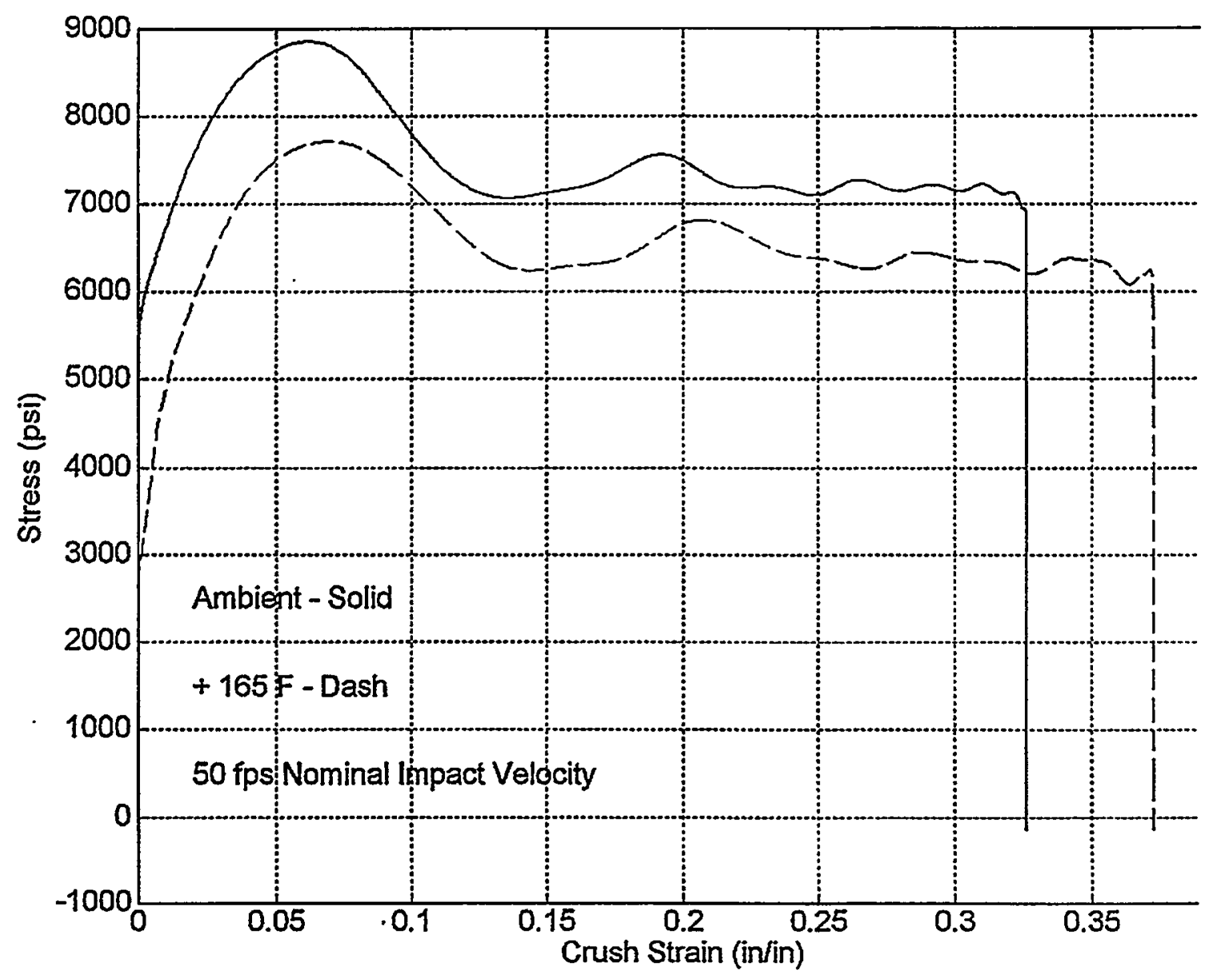

Figure 15

Segmented Alcore Honeycomb, Averaged Crush Characteristics Comparison, DC-2000 Hz Bandwidth. 


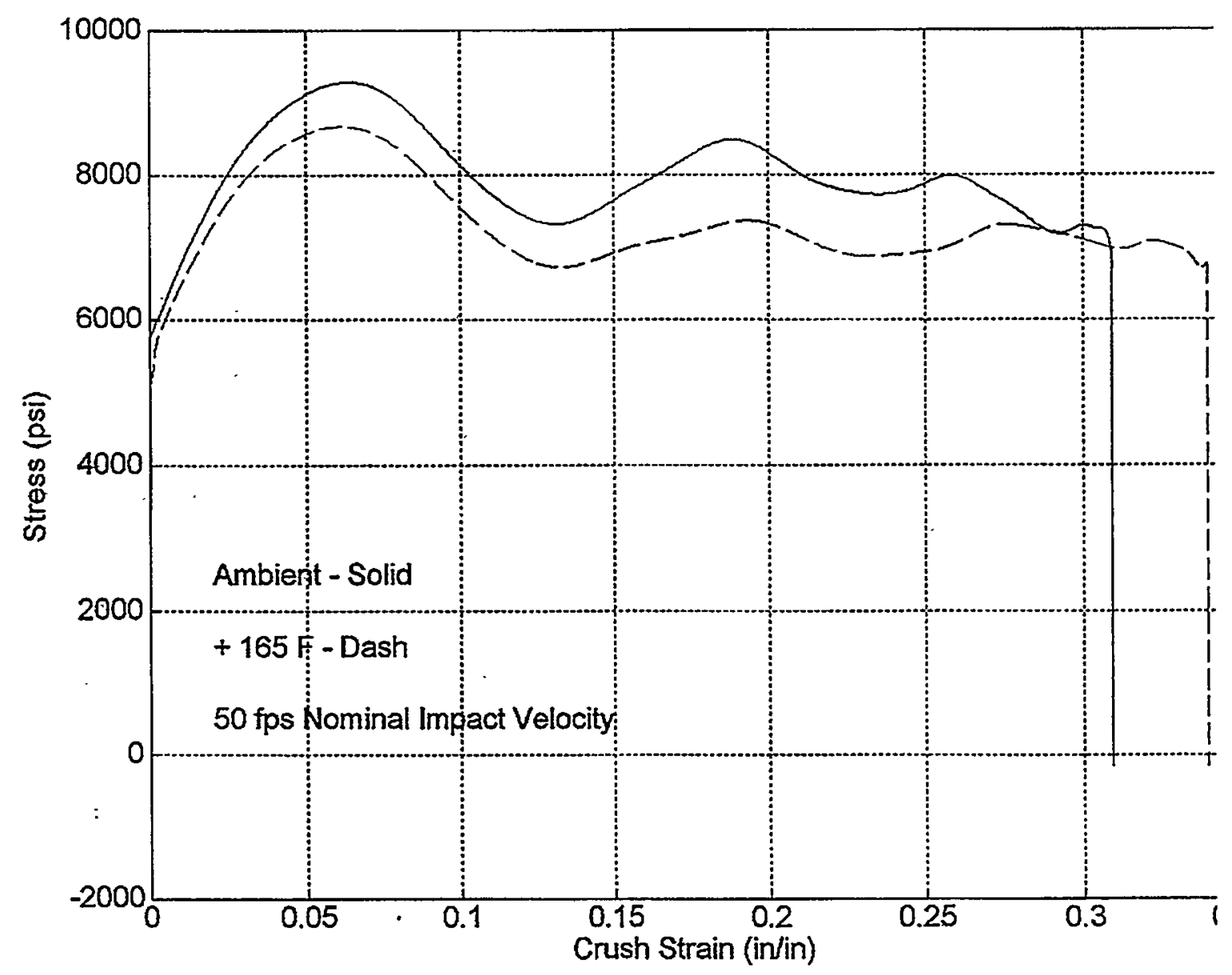

Figure 16

Segmented Hexcel Honeycomb, Averaged Crush Characteristics Comparison, DC-2000 Hz Bandwidth. 


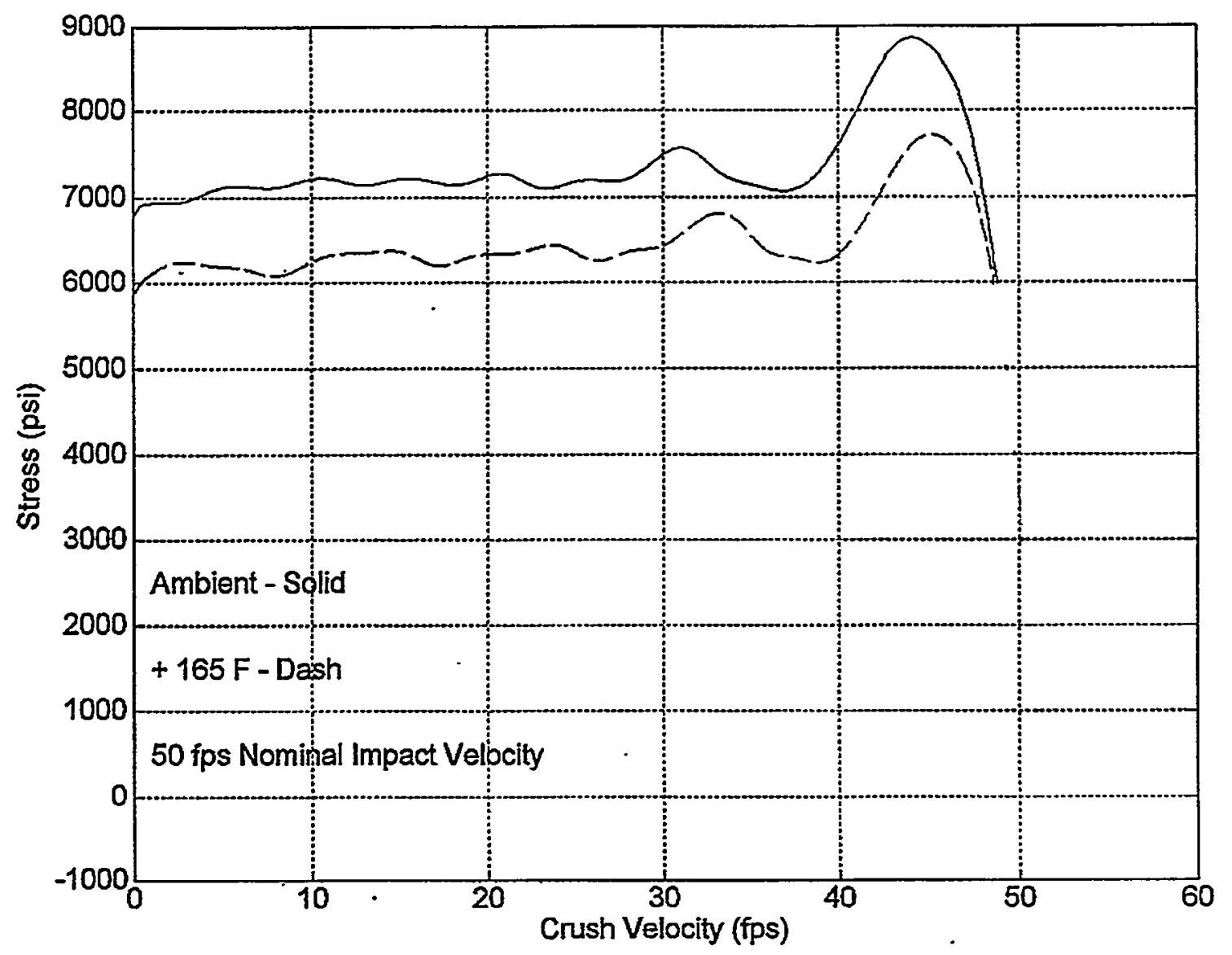

Figure 17

Segmented Alcore Honeycomb Averaged Crush Characteristics Comparison as a Function of Velocity, DC-2000 Hz Bandwidth. 


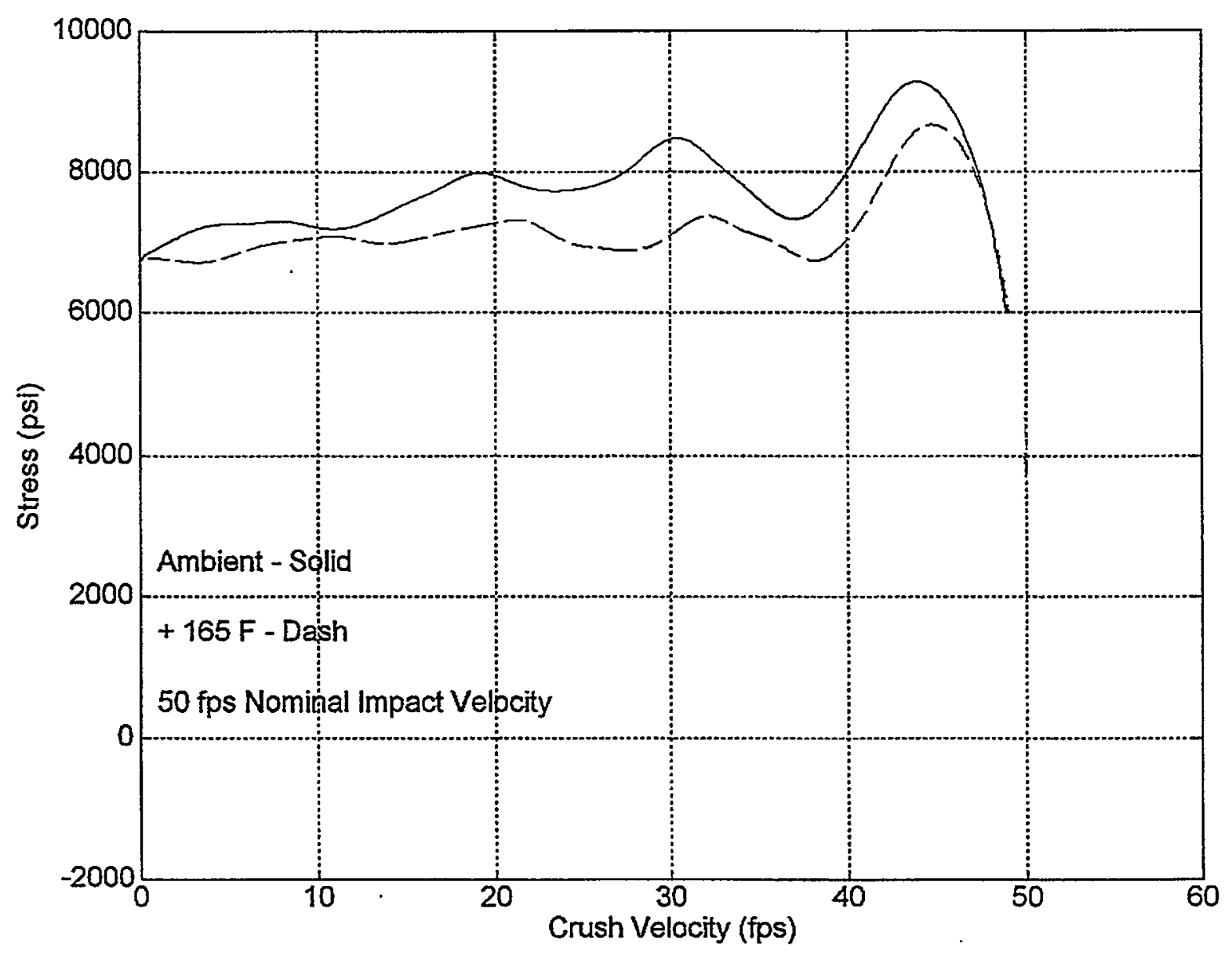

Figure 18

Segmented Hexcel Honeycomb Averaged Crush Characteristics Comparison as a Function of Velocity, DC-2000 Hz Bandwidth 


\section{References}

1. Bateman, V. I., F. A. Brown, and M. A. Nusser, "High Shock, High Frequency Characteristics of a Mechanical Isolator for a Piezoresistive Accelerometer, the ENDEVCO 7270AM6," SAND00-1528, National Technical Information Service, 5285 Port Royal Road, Springfield, VA 22162, July 2000.

2. Bateman, V. I., R. L. Mayes, and T. G. Carne, "A Comparison of Force Reconstruction Methods for a Lumped Mass Beam," Shock and Vibration Journal, Vol. 4, Issue 4, 1997, pp.231-240.

3. Lu, Wei-Yang, "Quasi-static Crush Tests of Alcore Segmented Samples at Ambient Temperature," Sandia Technical Memos, Sandia National Laboratories, Livermore, CA, 11/30/99.

4. Lu, Wei-Yang, "Quasi-static Crush Tests of Hexcel Segmented Samples at Ambient Temperature," Sandia Technical Memos, Sandia National Laboratories, Livermore, CA, 12/13/99.

5. Lu, Wei-Yang, "Moderate Rate Confined Crush Tests of 38 pcf Honeycombs in the T-direction at Ambient," Sandia Technical Memos, Sandia National Laboratories, Livermore, CA, 12/3/99 and 1/10/2000.

6. Lu, Wei-Yang, "Moderate Rate Confined Crush Tests of 38 pcf Honeycombs in the T-direction at + $165^{\circ} \mathrm{F}$," Sandia Technical Memos, Sandia National Laboratories, Livermore, CA, 1/18/2000.

7. Lu, Wei-Yang, "Moderate Rate Confined Crush Tests of 38 pcf Honeycombs in the T-direction at $-65^{\circ} \mathrm{F}$," Sandia Technical Memos, Sandia National Laboratories, Livermore, CA, 2/25/2000.

8. Bateman, V. I. and L. H. Swanson, "Aluminum Honeycomb Characteristics in Dynamic Crush Environments," SAND99-1781, National Technical Information Service, 5285 Port Royal Road, Springfield, VA 22162, July 1999.

9. Ulibarri, Davie, and Kuehnle, "Mechanical Shock Test Instrumentation," Sandia National Laboratories Specification 9958003-4, 1992, pp. 1-19.

10. Bateman, V. I., "Data Acquisition System Hardware Fidelity Check Procedures," February 14, 1997, pp. 1-21.

11. Bateman, V. I., "Software Management Plan for Software Supporting Production Lot Acceptance Testing," January 11, 1996, pp. 1-5.

12. Bateman, V. I., "Software Quality Requirements for Area I Mechanical Shock Laboratory," Issue A, January 11, 1996, pp. 1-10.

13. Bateman, V. I. And O. M. Solomon, Jr., "Characterization of Accelerometer Mountings in Shock Environments," Proceedings of the 14th Transducer Workshop, Colorado Springs, CO, June 1987.

14. Doebelin, E. O., "Measurement Systems Application and Design," McGraw Hill Book Company, New York, N. Y., 1983, pp.57-60.

15. Abernathy, R. B. "Measurement Uncertainty Handbook," Instrument Society of America, Research Triangle Park, N.C., 1980. 


\section{Appendix A}

\section{Load Cell Static Calibration and Modal Analysis Results}




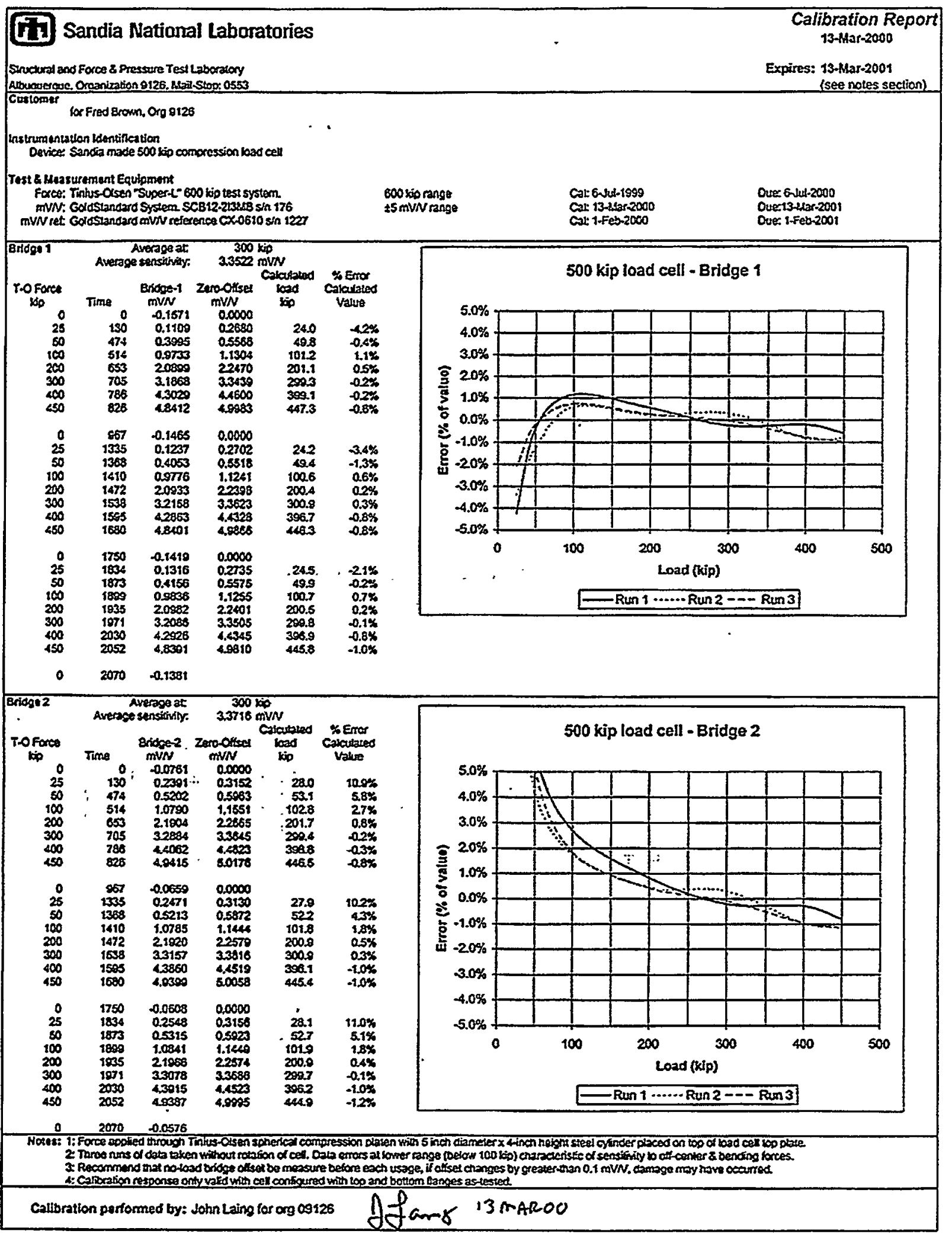




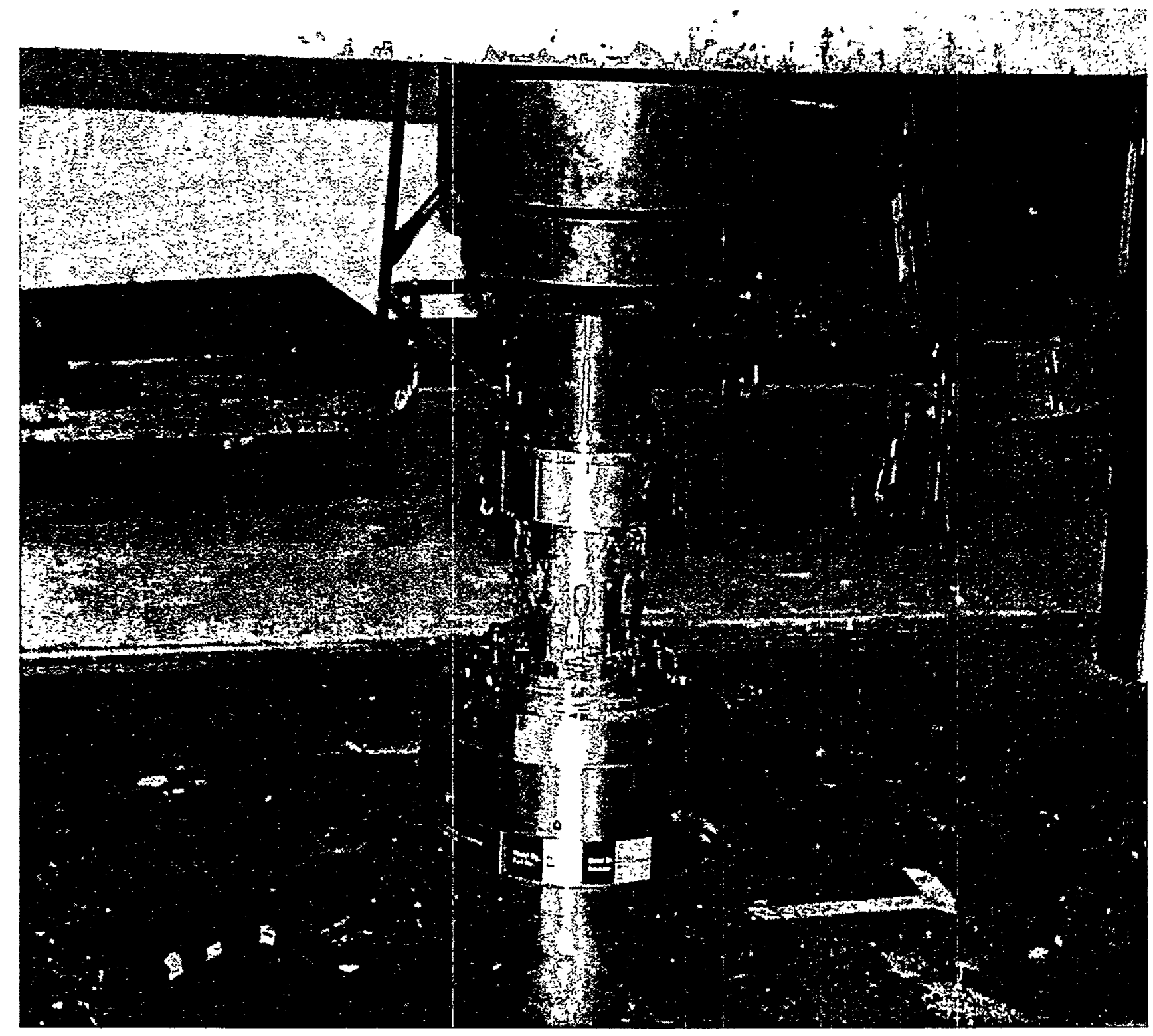

Load Cell Static Calibration Configuration on Tinius Olsen Machine 


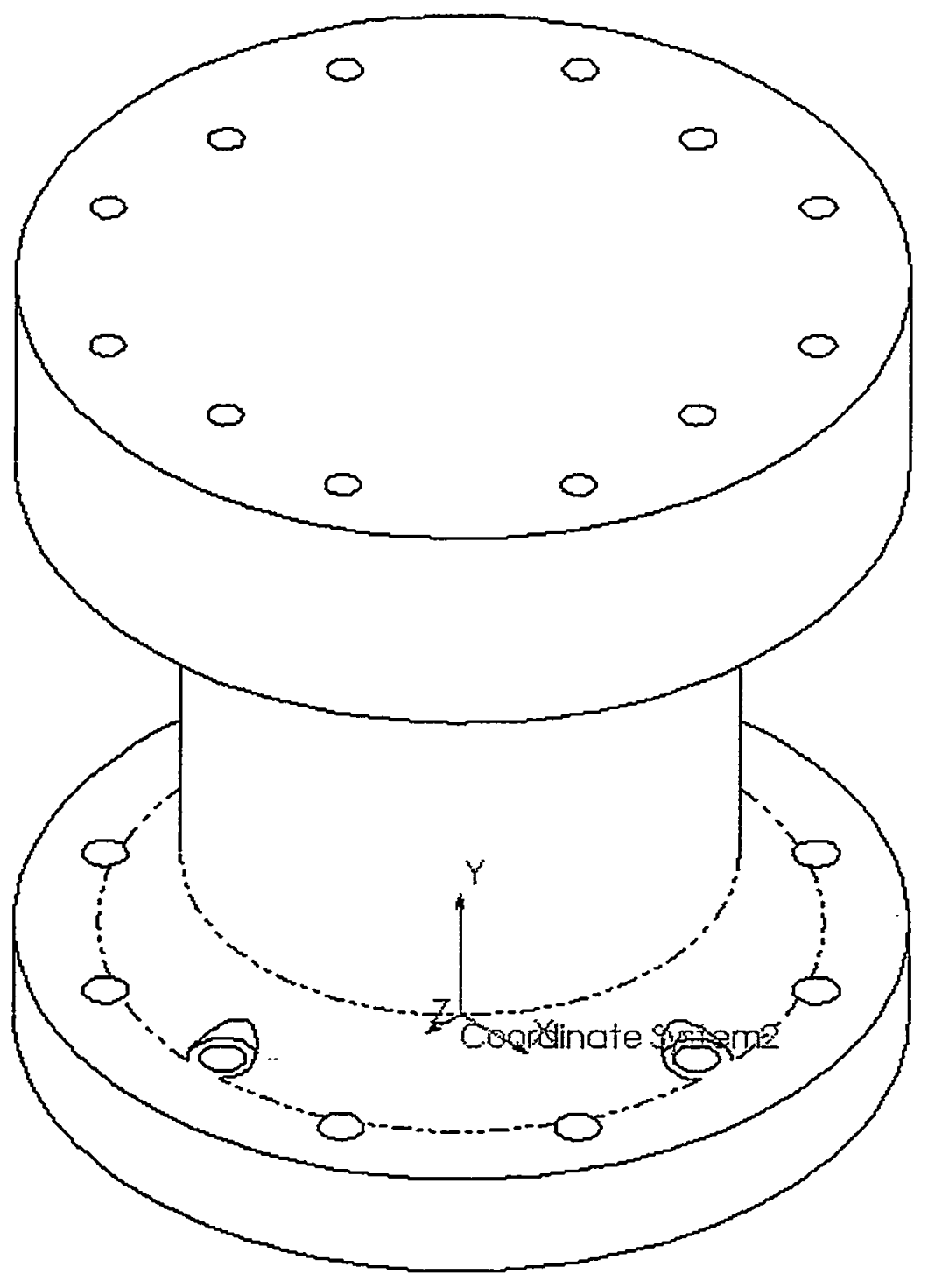

Undeformed Load Cell Model (Solid Works) with Coordinate System. 
Results of Two Modal Analyses for the Load Cell.

\begin{tabular}{|c|c|c|c|c|}
\hline $\begin{array}{l}\text { Mode } \\
\text { No. }\end{array}$ & $\begin{array}{l}\text { Modal } A^{*} \\
\text { Frequency }\end{array}$ & $\begin{array}{l}\text { Modal A* } \\
\text { Description }\end{array}$ & $\begin{array}{l}\text { Modal B** } \\
\text { Frequency }\end{array}$ & $\begin{array}{l}\text { Modal B }{ }^{* *} \\
\text { Description }\end{array}$ \\
\hline 1 & $8390 \mathrm{~Hz}$ & $\begin{array}{c}\text { First Bending Mode } \\
\text { X-Y Plane }\end{array}$ & $1274 \mathrm{~Hz}$ & $\begin{array}{c}\text { First Bending Mode } \\
\text { X-Y Plane }\end{array}$ \\
\hline 2 & $8390 \mathrm{~Hz}$ & $\begin{array}{c}\text { First Bending Mode } \\
\text { Y-Z Plane }\end{array}$ & $1275 \mathrm{~Hz}$ & $\begin{array}{c}\text { First Bending Mode } \\
\text { Y-Z Plane }\end{array}$ \\
\hline$\overline{3}$ & $9510 \mathrm{~Hz}$ & $\begin{array}{c}\text { First Ovaling Mode } \\
X-Y \text { Plane }\end{array}$ & $1985 \mathrm{~Hz}$ & $\begin{array}{c}\text { Torsional Mode } \\
\text { about } Y \text { Axis }\end{array}$ \\
\hline 4 & $9560 \mathrm{~Hz}$ & $\begin{array}{c}\text { First Ovaling Mode } \\
\text { Y-Z Plane }\end{array}$ & $4137 \mathrm{~Hz}$ & Axial Mode Y-Axis \\
\hline 5 & $10,350 \mathrm{~Hz}$ & Axial Mode $Y$-Axis & $4212 \mathrm{~Hz}$ & $\begin{array}{c}\text { First Bending Mode } \\
\text { X-Y Plane }\end{array}$ \\
\hline 6 & $12,850 \mathrm{~Hz}$ & $\begin{array}{l}\text { Second Bending } \\
\text { Mode } X-Y \text { Plane }\end{array}$ & $4213 \mathrm{~Hz}$ & $\begin{array}{c}\text { First Bending Mode } \\
\text { Y-Z Plane }\end{array}$ \\
\hline$\overline{7}$ & $12,850 \mathrm{~Hz}$ & $\begin{array}{l}\text { Second Bending } \\
\text { Mode Y-Z Plane }\end{array}$ & $6833 \mathrm{~Hz}$ & $\begin{array}{c}\text { First Ovaling Mode } \\
\text { X-Y Plane }\end{array}$ \\
\hline 8 & $14,620 \mathrm{~Hz}$ & $\begin{array}{l}\text { Second Ovaling } \\
\text { Mode } X-Y \text { Plane }\end{array}$ & $6834 \mathrm{~Hz}$ & $\begin{array}{c}\text { First Ovaling Mode } \\
\text { Y-Z Plane }\end{array}$ \\
\hline 9 & $14,680 \mathrm{~Hz}$ & $\begin{array}{l}\text { Second Ovaling } \\
\text { Mode Y-Z Plane }\end{array}$ & $9736 \mathrm{~Hz}$ & $\begin{array}{c}\text { Second Ovaling } \\
\text { Mode X-Y Plane } \\
\end{array}$ \\
\hline 10 & $15,560 \mathrm{~Hz}$ & $\begin{array}{l}\text { Torsional Mode } \\
\text { about Y Axis }\end{array}$ & $10,050 \mathrm{~Hz}$ & $\begin{array}{l}\text { Second Bending } \\
\text { Mode X-Y Plane }\end{array}$ \\
\hline
\end{tabular}

*Modal Analysis A was performed with a model of the load cell created in Solid Works (Version 2000) with both ends of the load cell fixed by a Cosmos Works (Version 5.0) high quality finite element analysis with 20785 elements and 33384 nodes.

** Modal Analysis B was performed with a model of the load cell created in Solid Works (Version 2000) with the bottom fixed and a $175 \mathrm{lb}$ load for the carriage weight on top by a Cosmos Works (Version 5.0) high quality finite element analysis with 20785 elements and 33384 nodes.

***Includes significant motion of the carriage. 


\section{Appendix B}

\section{Comparison of DC-2000 Hz and DC-10,000 Hz SWAT-CAL and Load Cell Derived Stress Time History and Fourier Transforms (One Experiment from Each Set).}




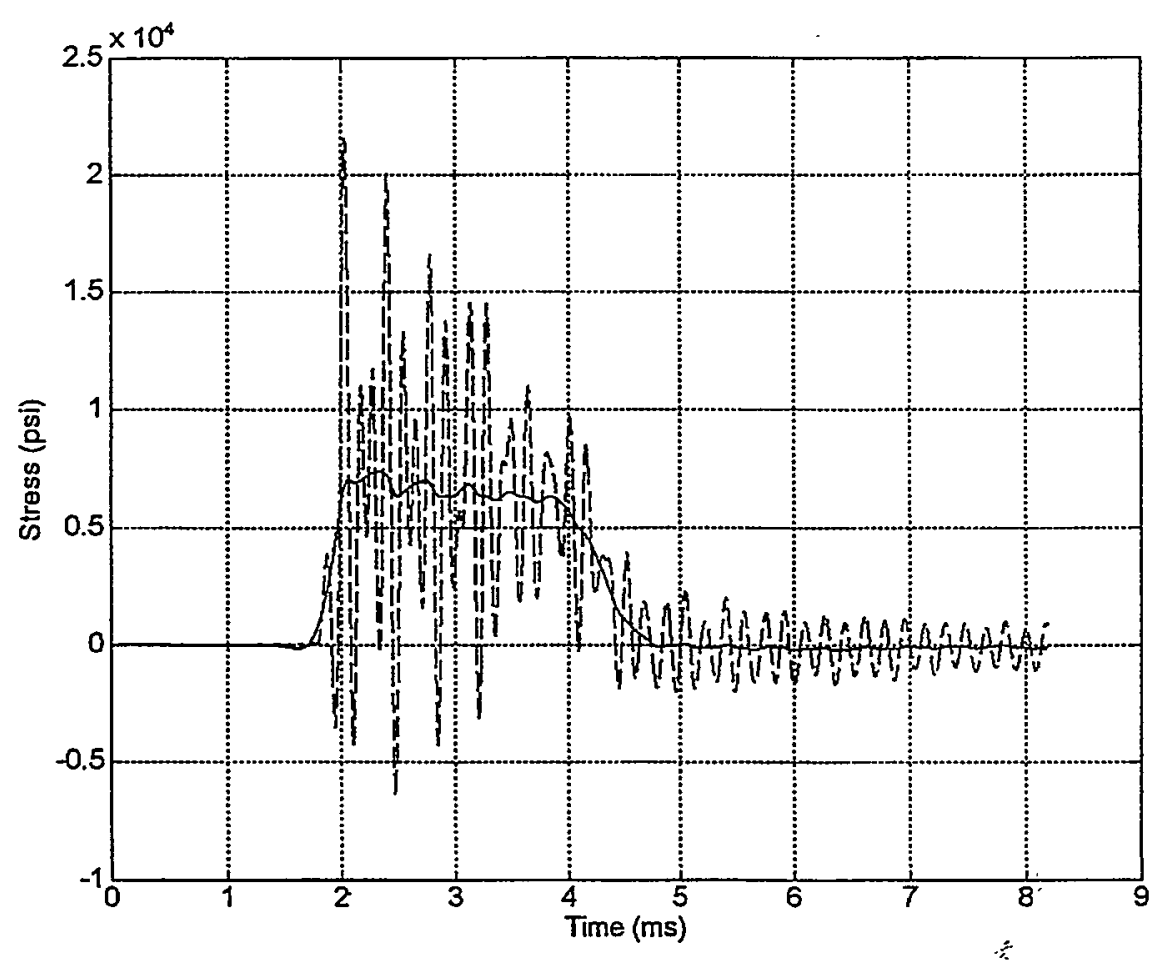

a) Time History Comparison

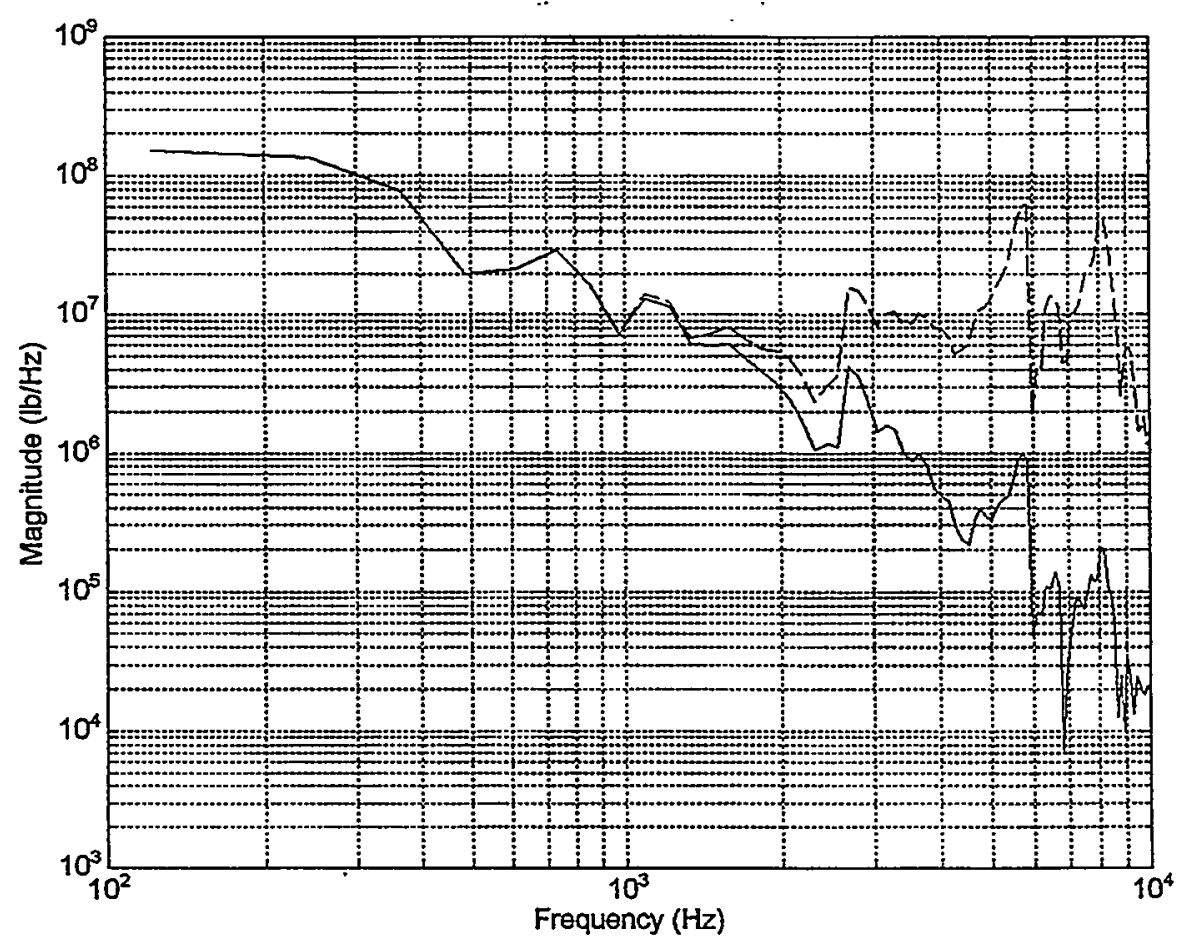

b) Fourier Transform Comparison

SWAT-CAL Stress Comparison: Solid - DC-2000 Hz and Dash - DC$10,000 \mathrm{~Hz}$ (Segmented Alcore Honeycomb at $+165^{\circ} \mathrm{F}$ Temperature). 


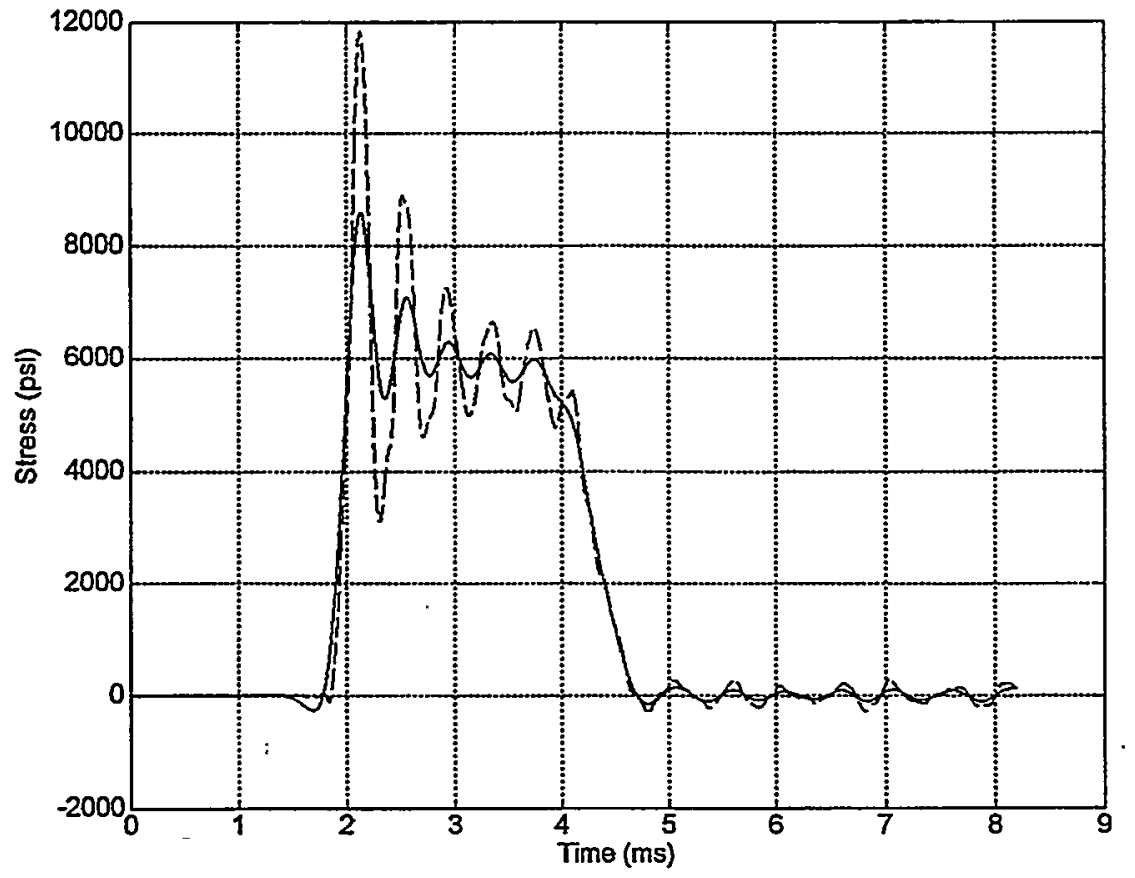

a) Time History Comparison

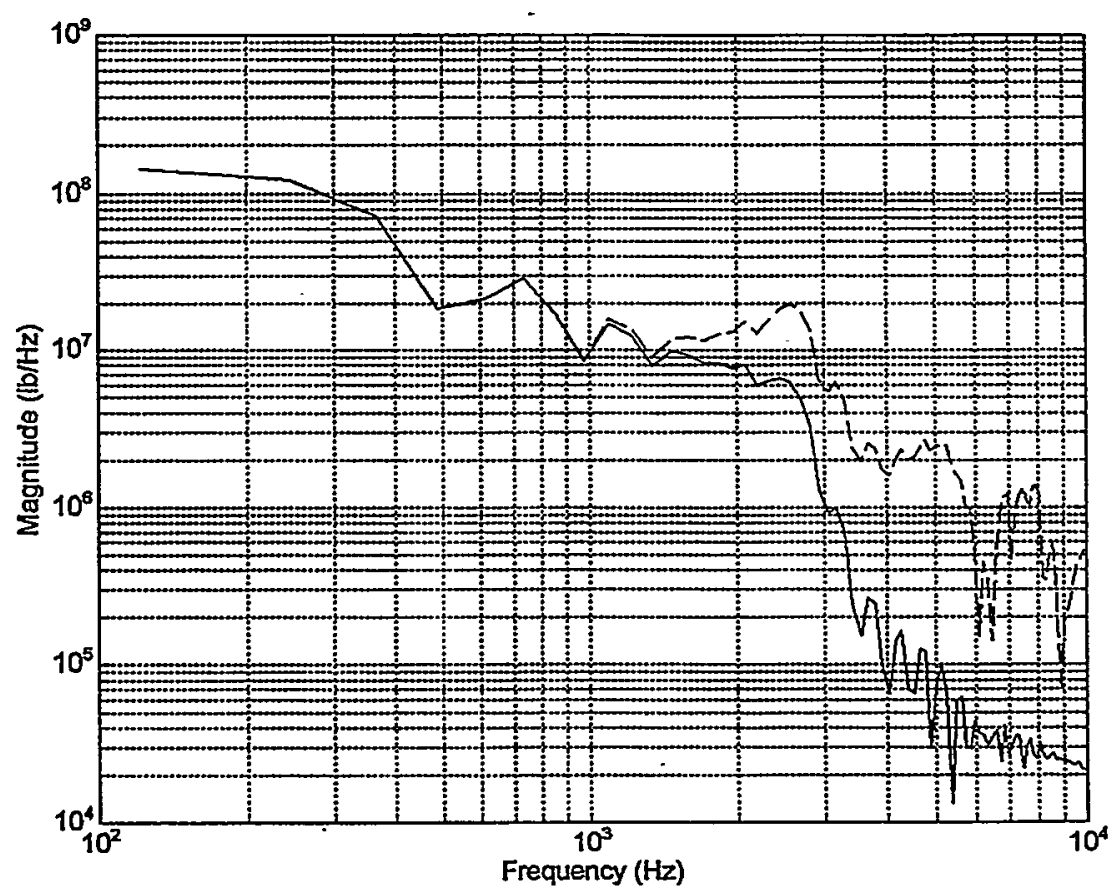

b) Fourier Transform Comparison

Load Cell Stress Comparison: Solid - DC-2000 Hz and Dash - DC$10,000 \mathrm{~Hz}$ (Segmented Alcore Honeycomb at $+165^{\circ} \mathrm{F}$ Temperature). 


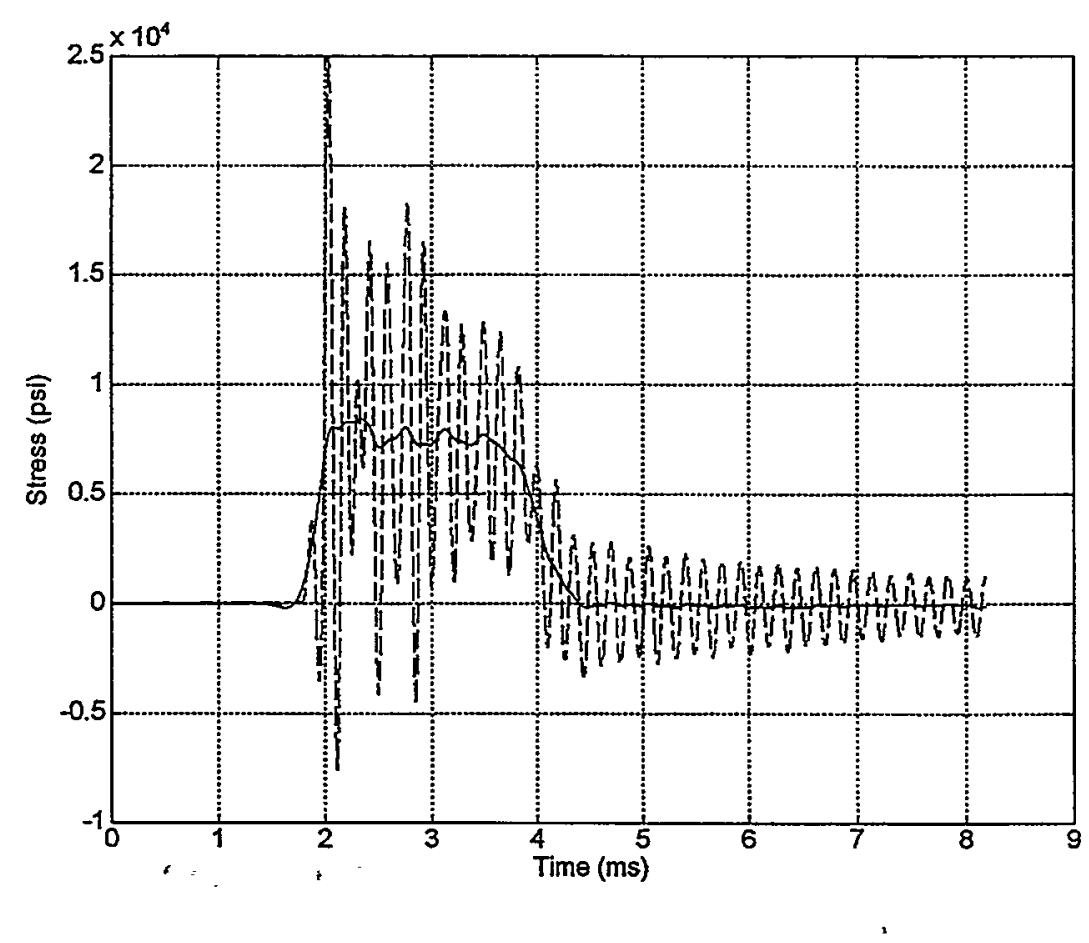

a) Time History Comparison

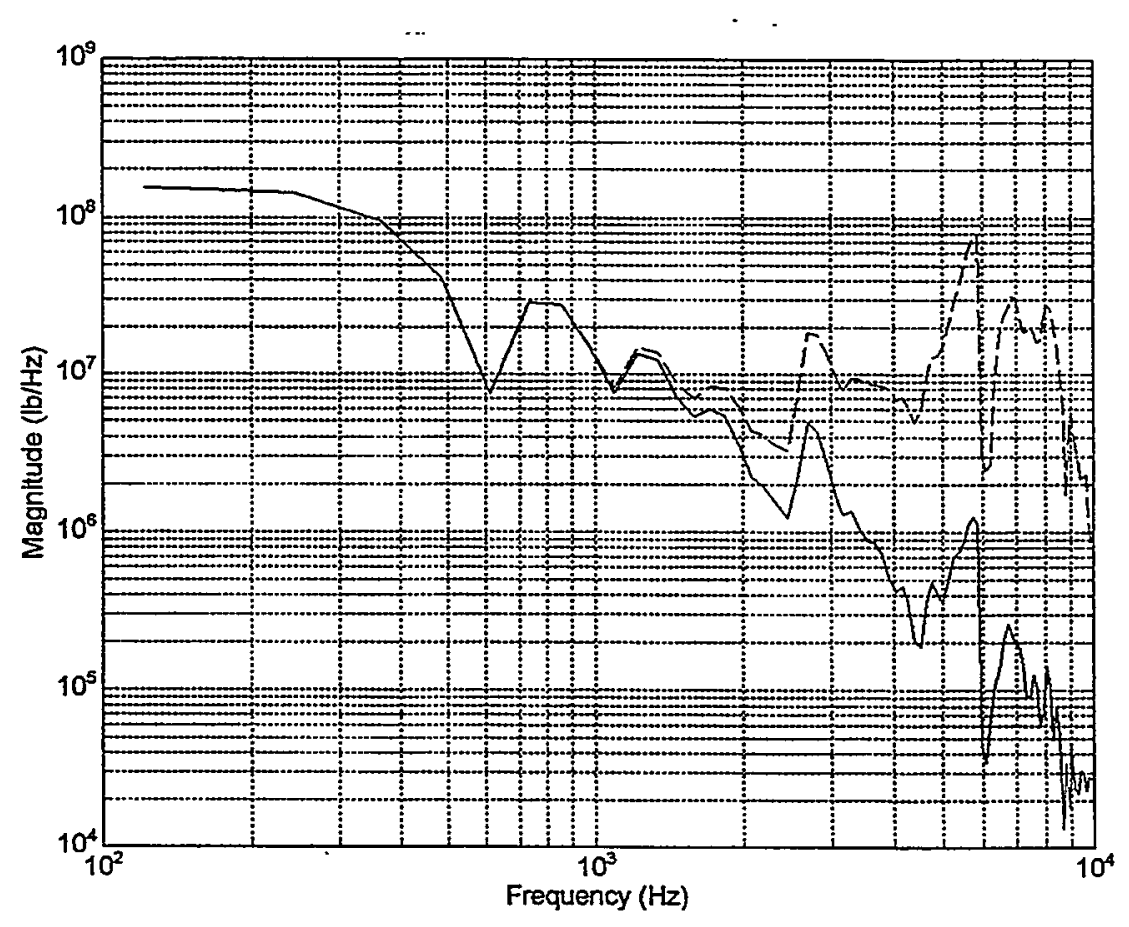

b) Fourier Transform Comparison

SWAT-CAL Stress Comparison: Solid - DC-2000 Hz and Dash - DC$10,000 \mathrm{~Hz}$ (Segmented Alcore Honeycomb at Ambient Temperature). 


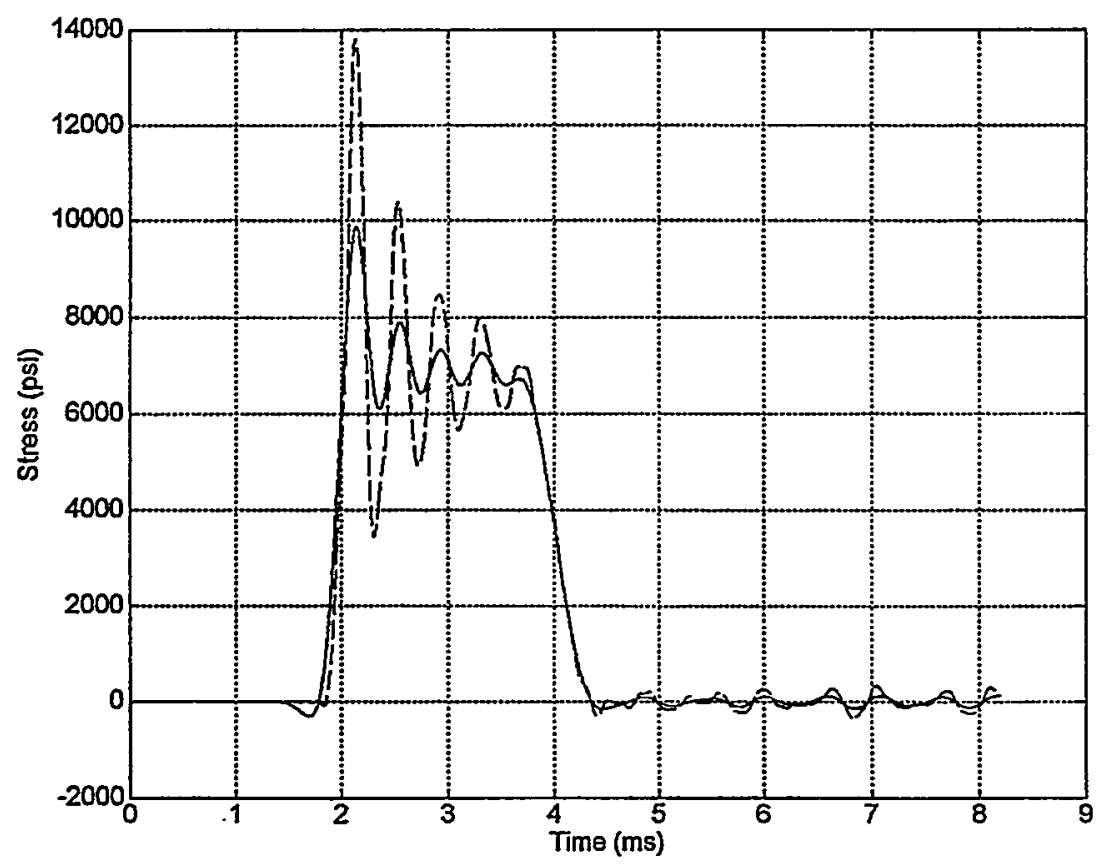

a) Time History Comparison

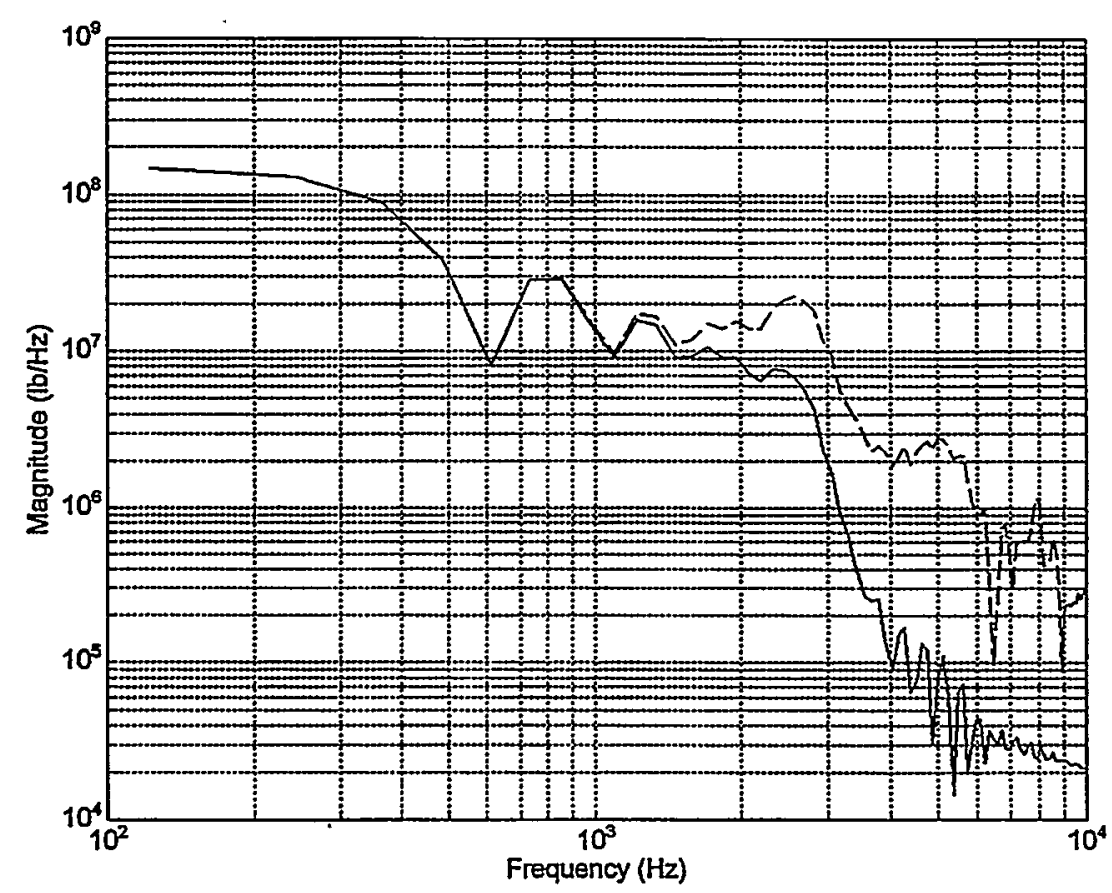

b) Fourier Transform Comparison

Load Cell Stress Comparison: Solid - DC-2000 Hz and Dash - DC$10,000 \mathrm{~Hz}$ (Segmented Alcore Honeycomb at Ambient Temperature). 


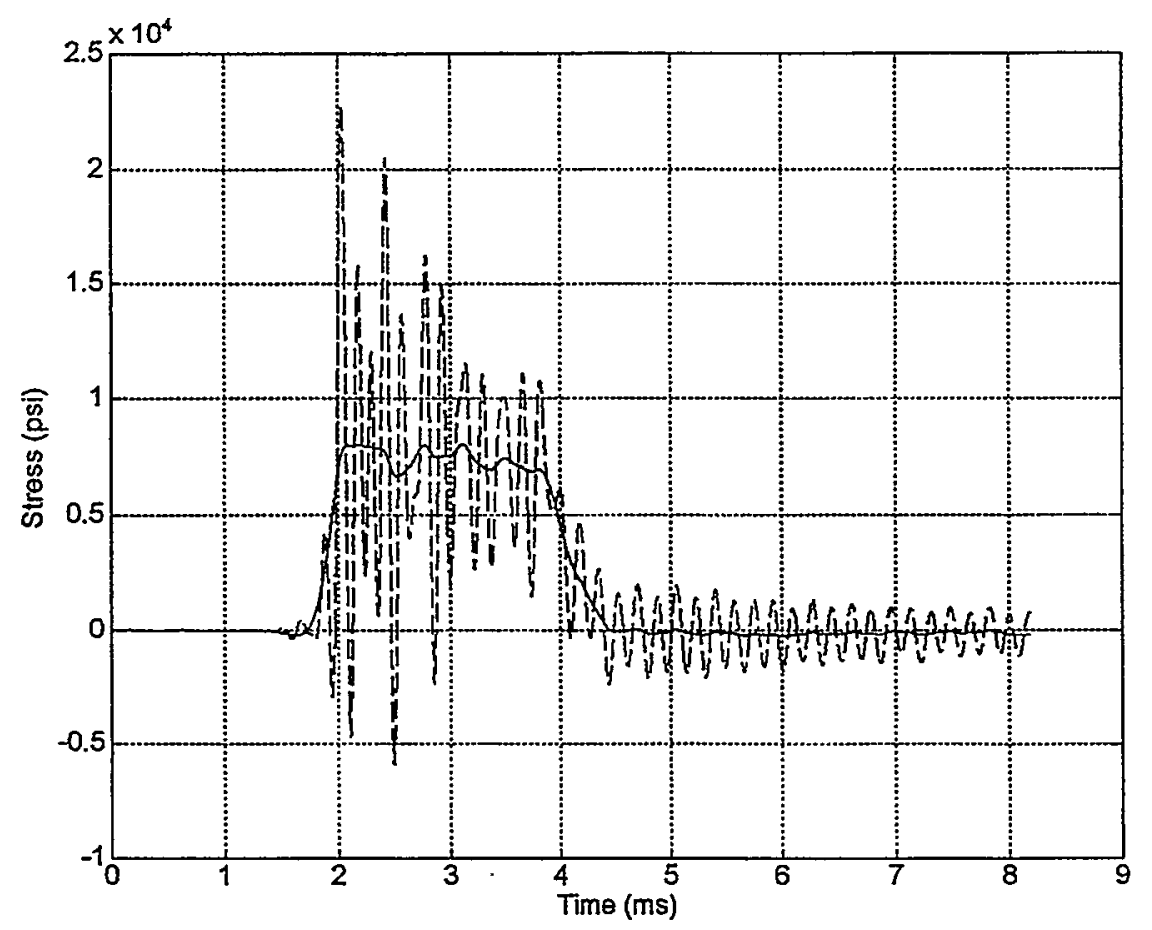

a) Time History Comparison

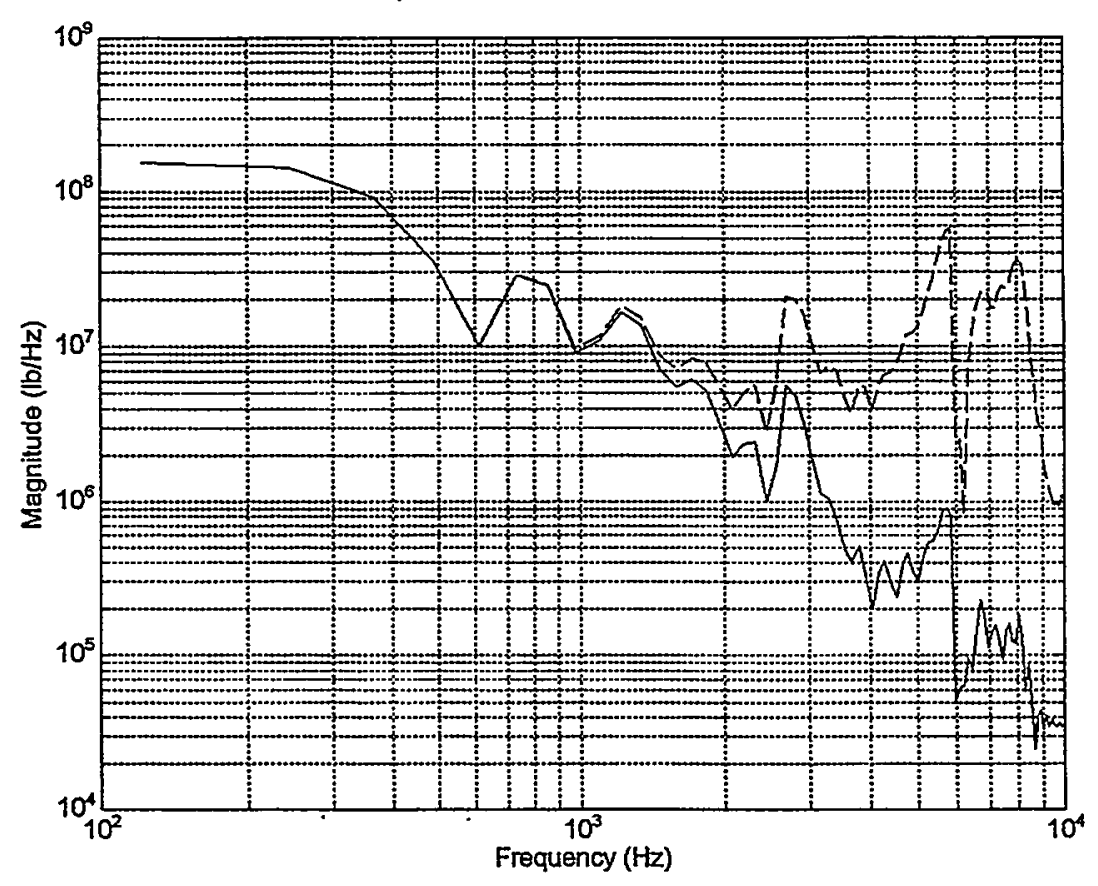

b) Fourier Transform Comparison

SWAT-CAL Stress Comparison: Solid - DC-2000 Hz and Dash - DC$10,000 \mathrm{~Hz}$ (Segmented Hexcel Honeycomb at $+165^{\circ} \mathrm{F}$ Temperature). 


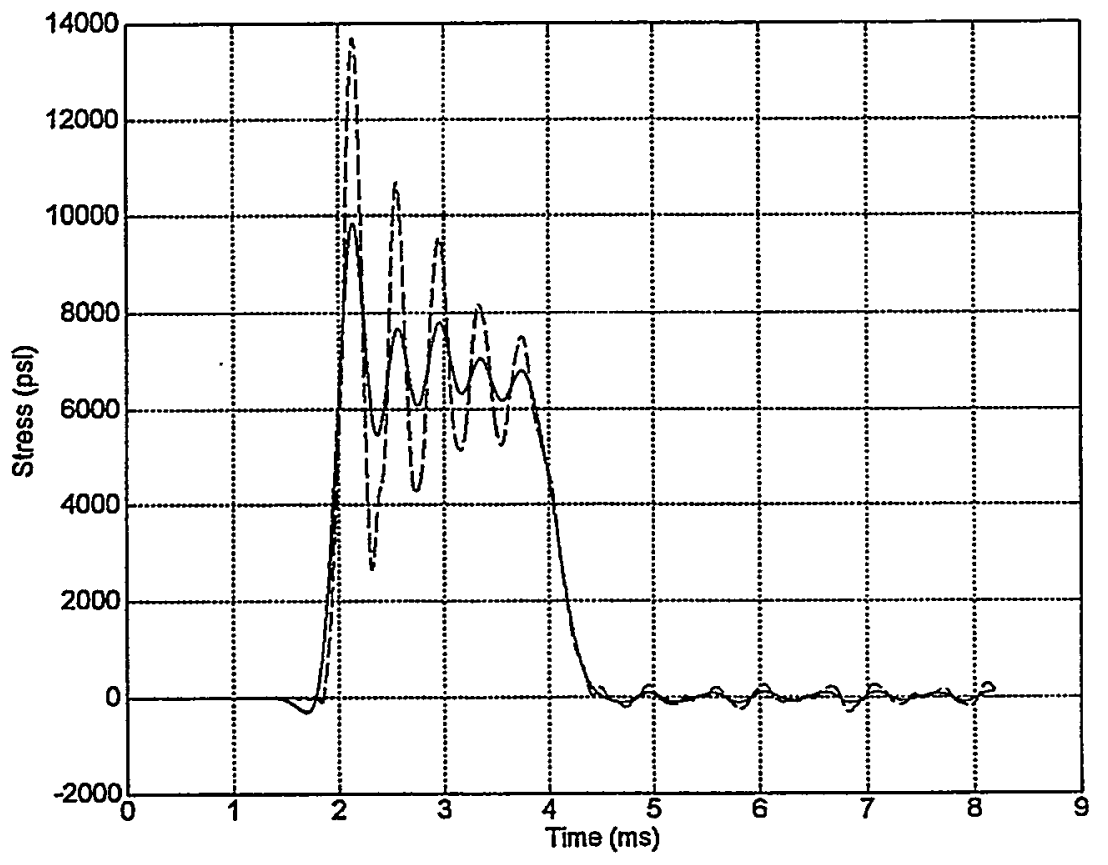

a) Time History Comparison

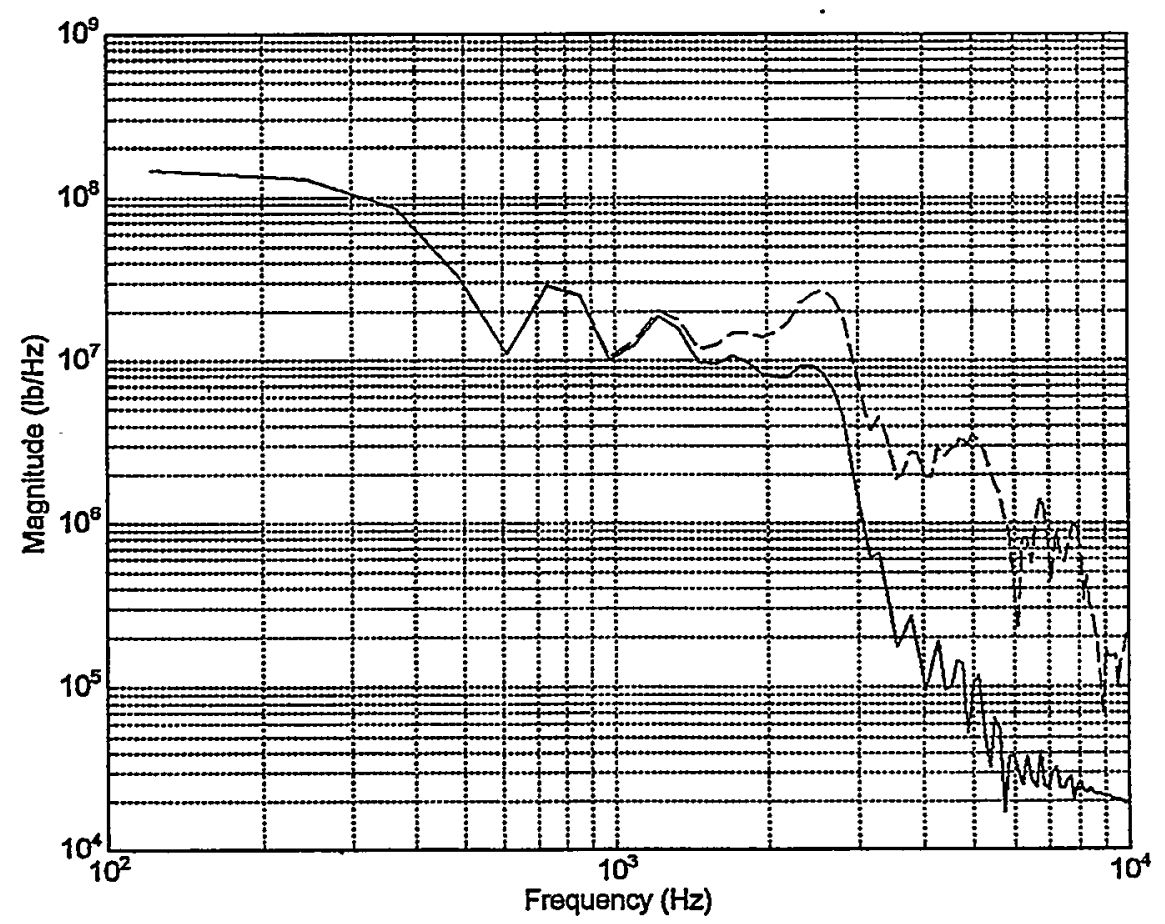

b) Fourier Transform Comparison

Load Cell Stress Comparison: Solid - DC-2000 Hz and Dash - DC$10,000 \mathrm{~Hz}$ (Segmented Hexcel Honeycomb at $+165^{\circ} \mathrm{F}$ Temperature). 


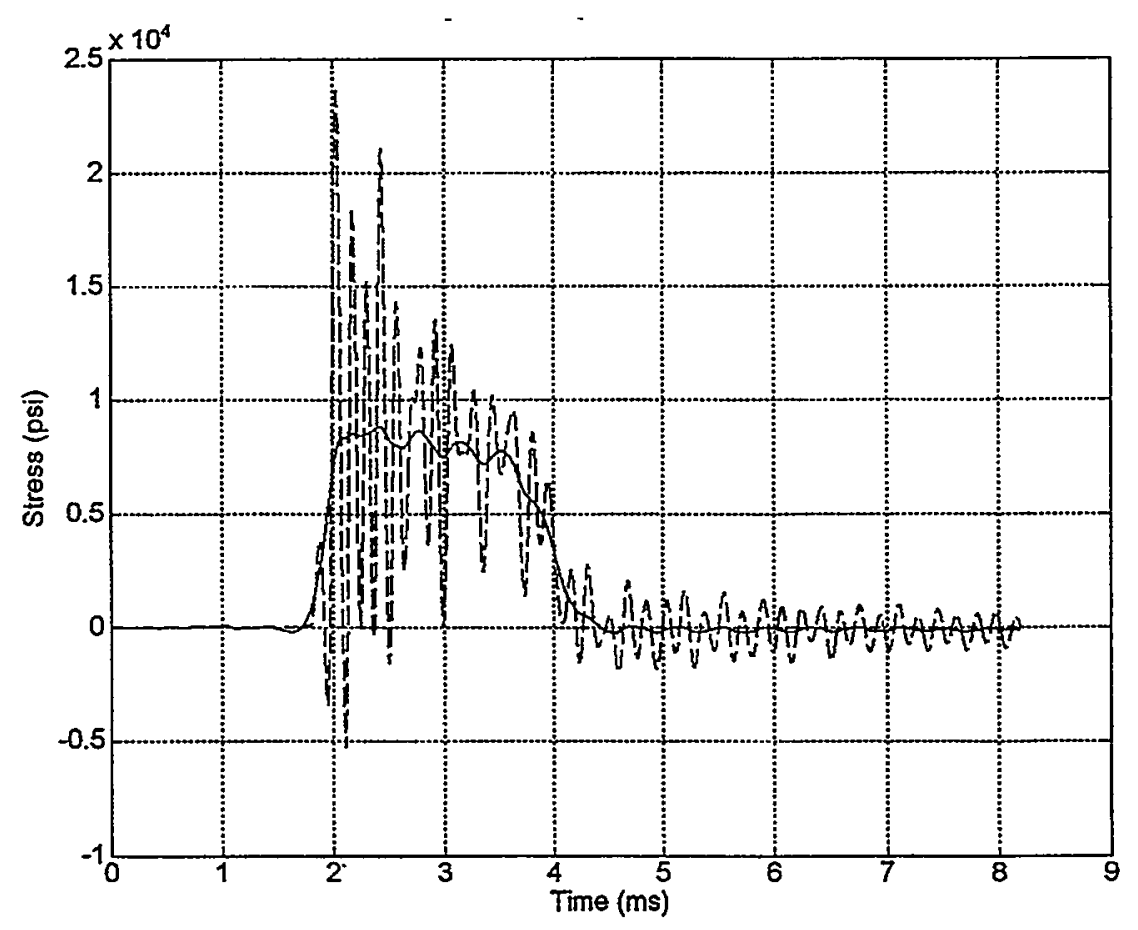

a) Time History Comparison

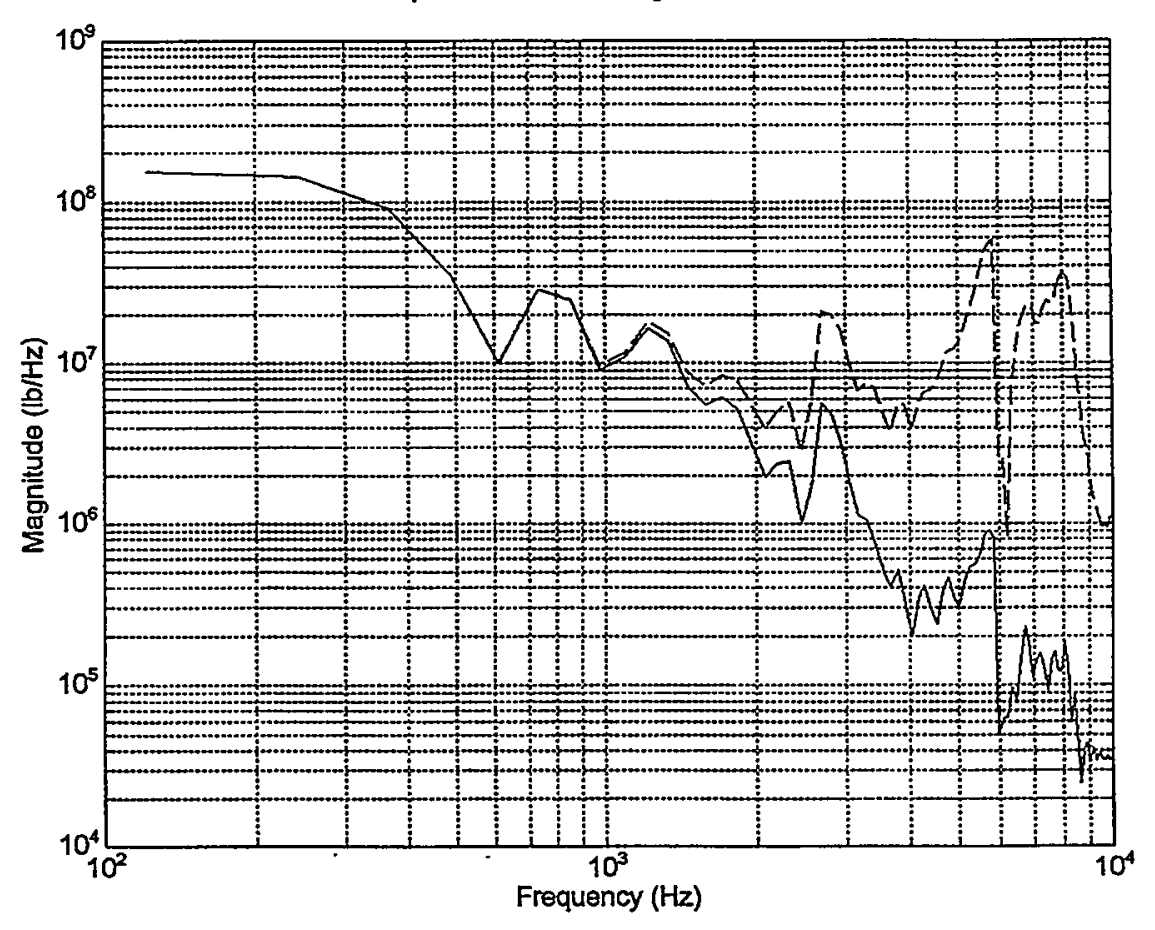

b) Fourier Transform Comparison

SWAT-CAL Stress Comparison: Solid - DC-2000 Hz and Dash - DC$10,000 \mathrm{~Hz}$ (Segmented Hexcel Honeycomb at Ambient Temperature). 


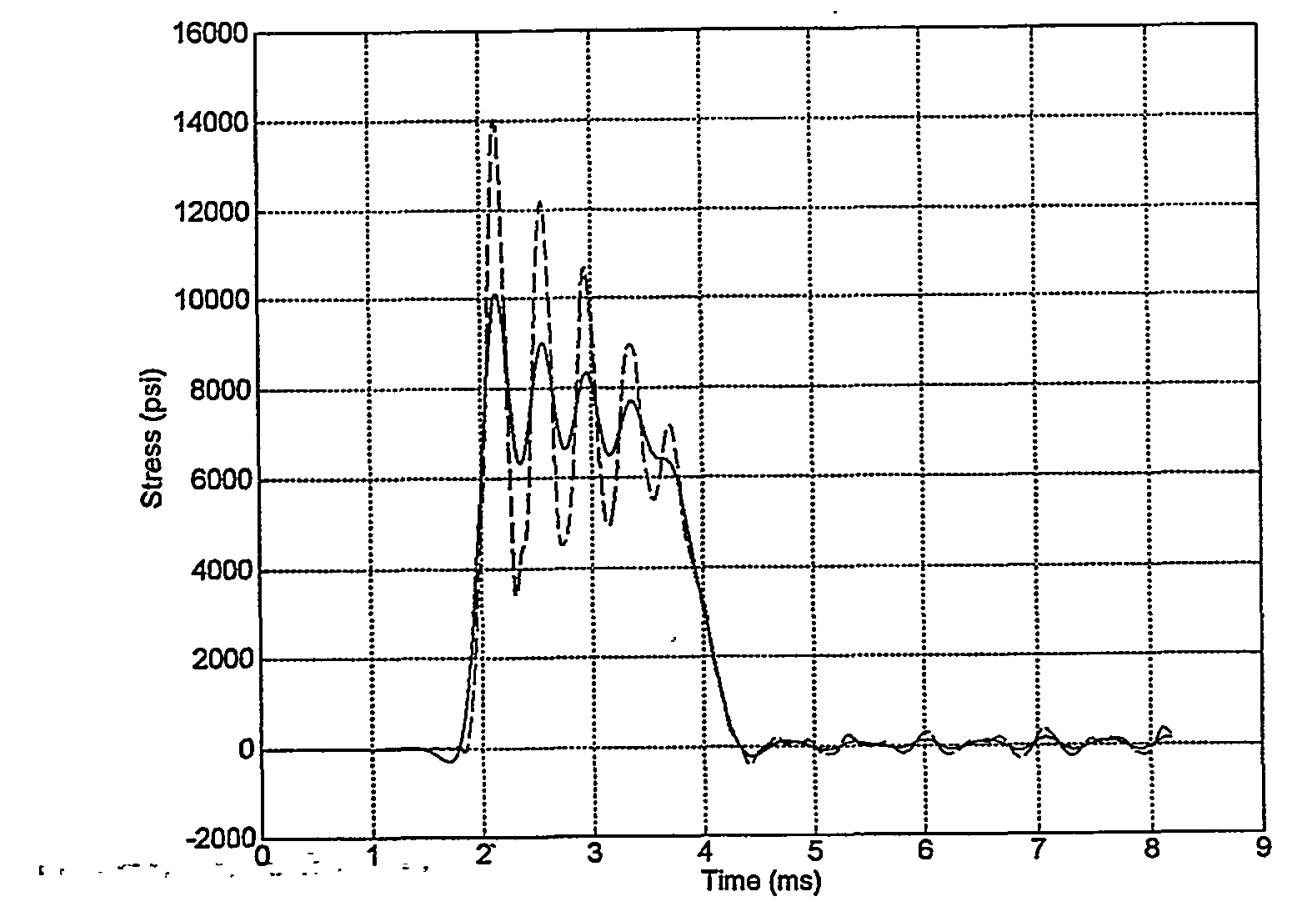

a) Time History Comparison

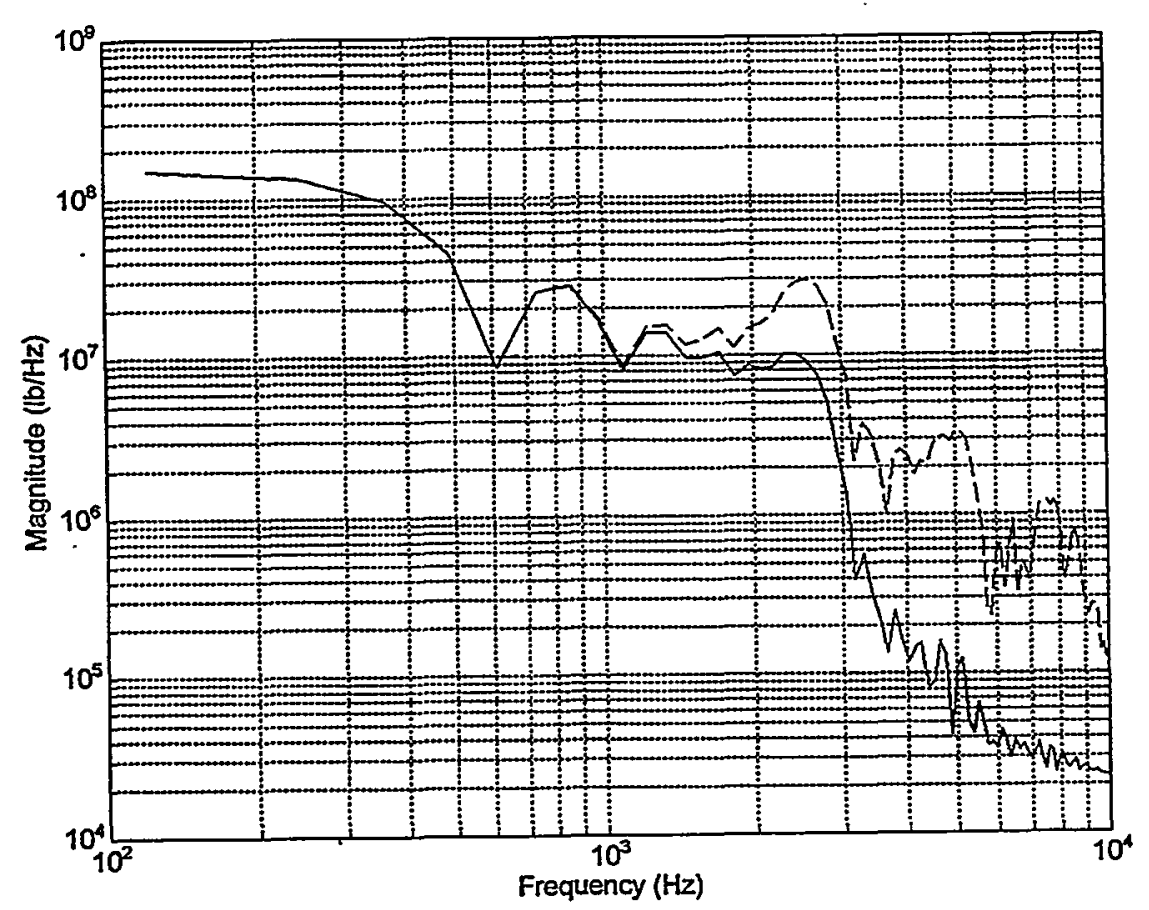

b) Fourier Transform Comparison

Load Cell Stress Comparison: Solid - DC-2000 Hz and Dash - DC$10,000 \mathrm{~Hz}$ (Segmented Hexcel Honeycomb at Ambient Temperature). 


\section{Appendix C}

Comparison SWAT-CAL and Load Cell Derived Stress Time History and Fourier Transforms, DC-2000 Hz Bandwidth (One Experiment from Each Set). 


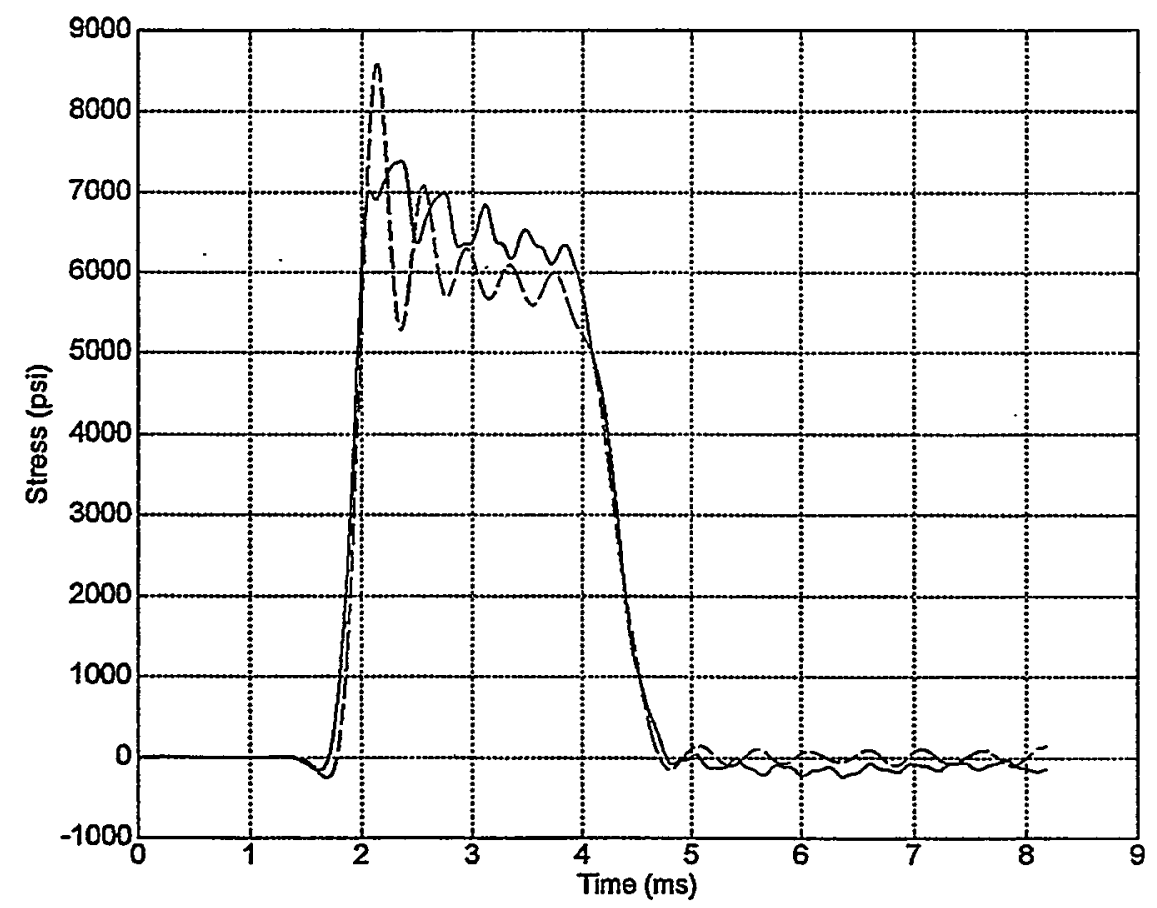

a) Time History Comparison

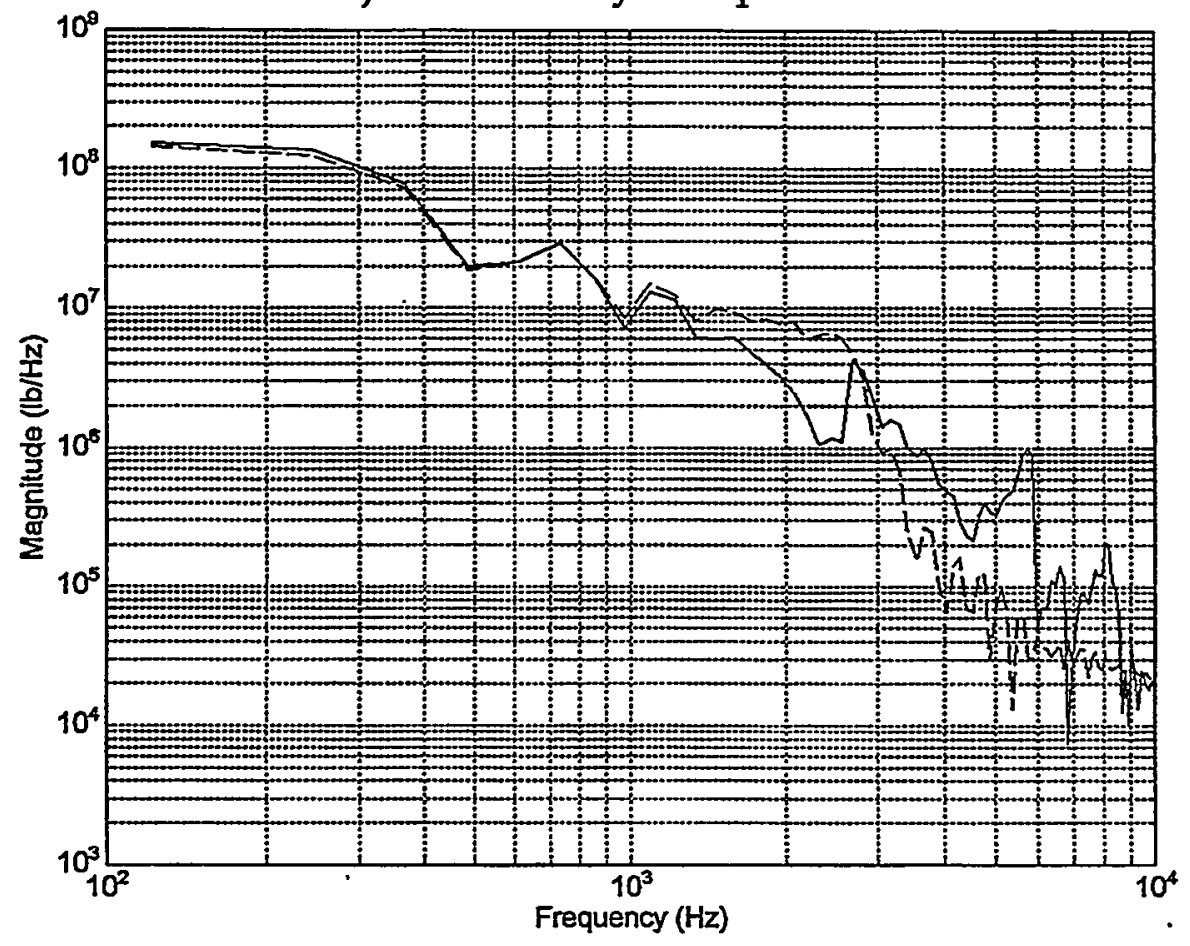

b) Fourier Transform Comparison

SWAT-CAL - Solid and Load Cell - Dash Stress Comparison, DC-2000 Hz Bandwidth

(Segmented Alcore Honeycomb at $+165^{\circ} \mathrm{F}$ Temperature). 

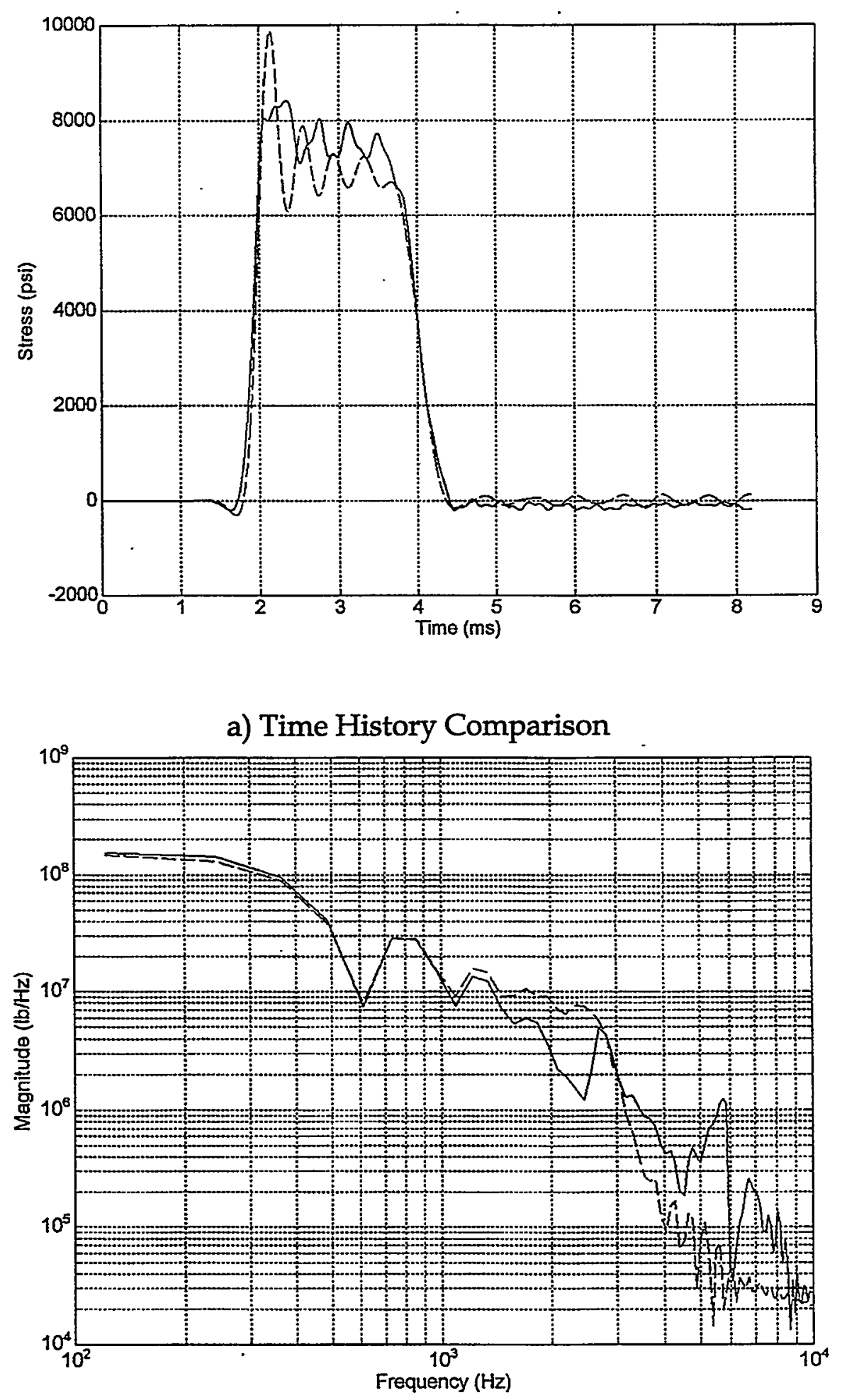

b) Fourier Transform Comparison

SWAT-CAL - Solid and Load Cell - Dash Stress Comparison, DC- $2000 \mathrm{~Hz}$ Bandwidth

(Segmented Alcore Honeycomb at Ambient Temperature). 

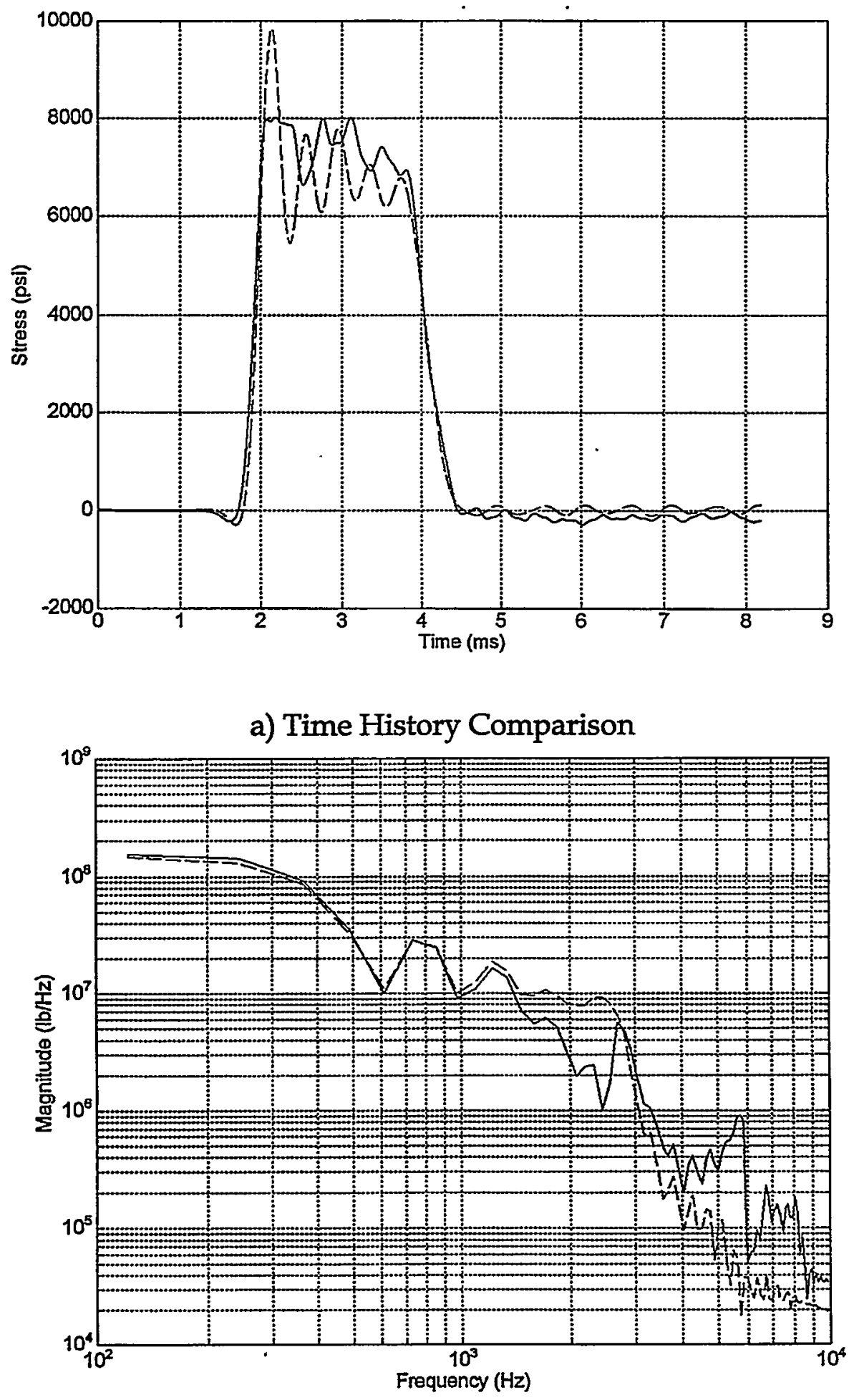

b) Fourier Transform Comparison

\section{SWAT-CAL - Solid and Load Cell - Dash Stress Comparison, DC-2000 Hz Bandwidth \\ (Segmented Hexcel Honeycomb at $+165^{\circ} \mathrm{F}$ Temperature).}



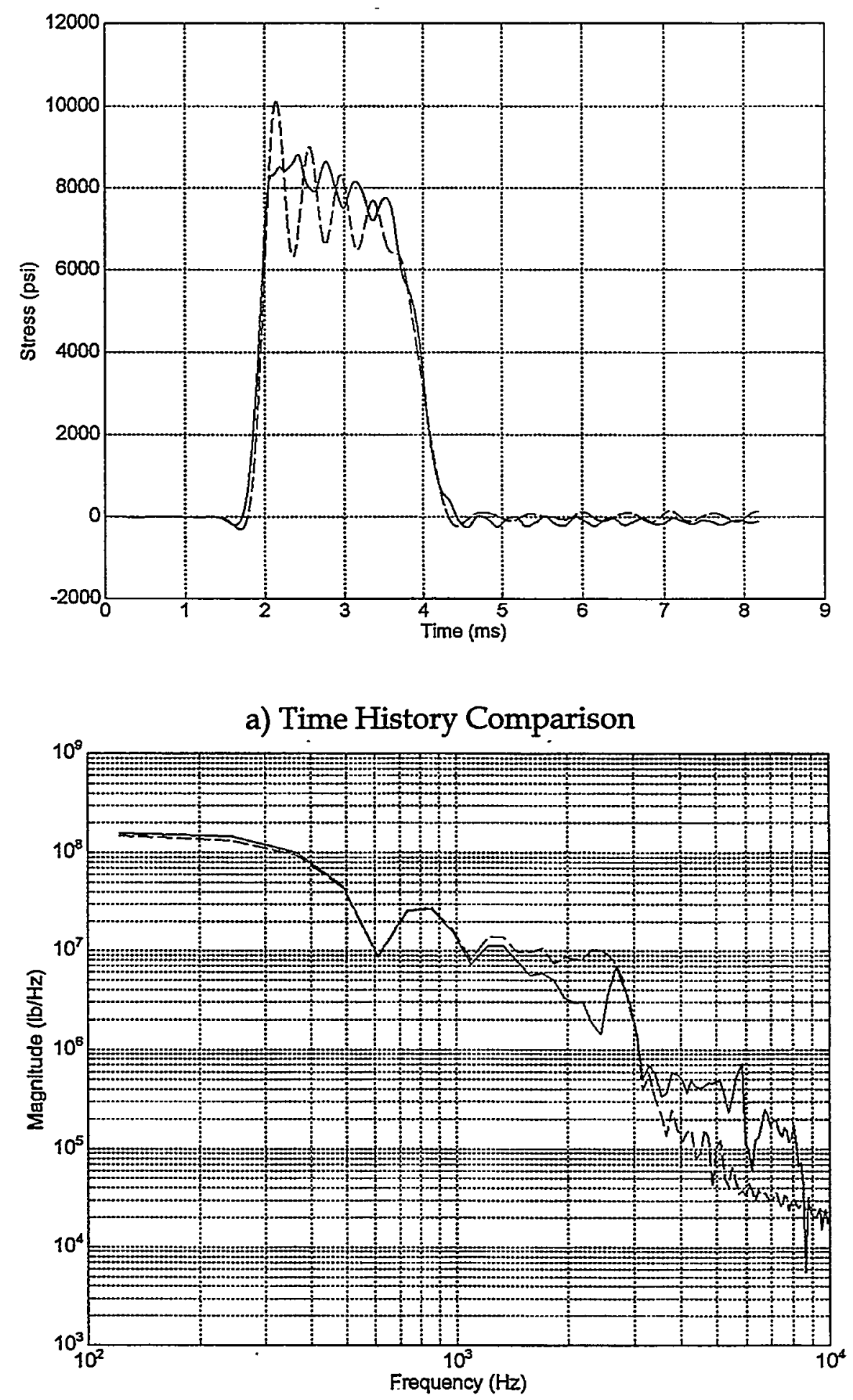

b) Fourier Transform Comparison

SWAT-CAL - Solid and Load Cell - Dash Stress Comparison, DC- $2000 \mathrm{~Hz}$ Bandwidth

(Segmented Hexcel Honeycomb at Ambient Temperature). 


\section{Appendix D}

Normalized Segmented Honeycomb Crush Characteristics 


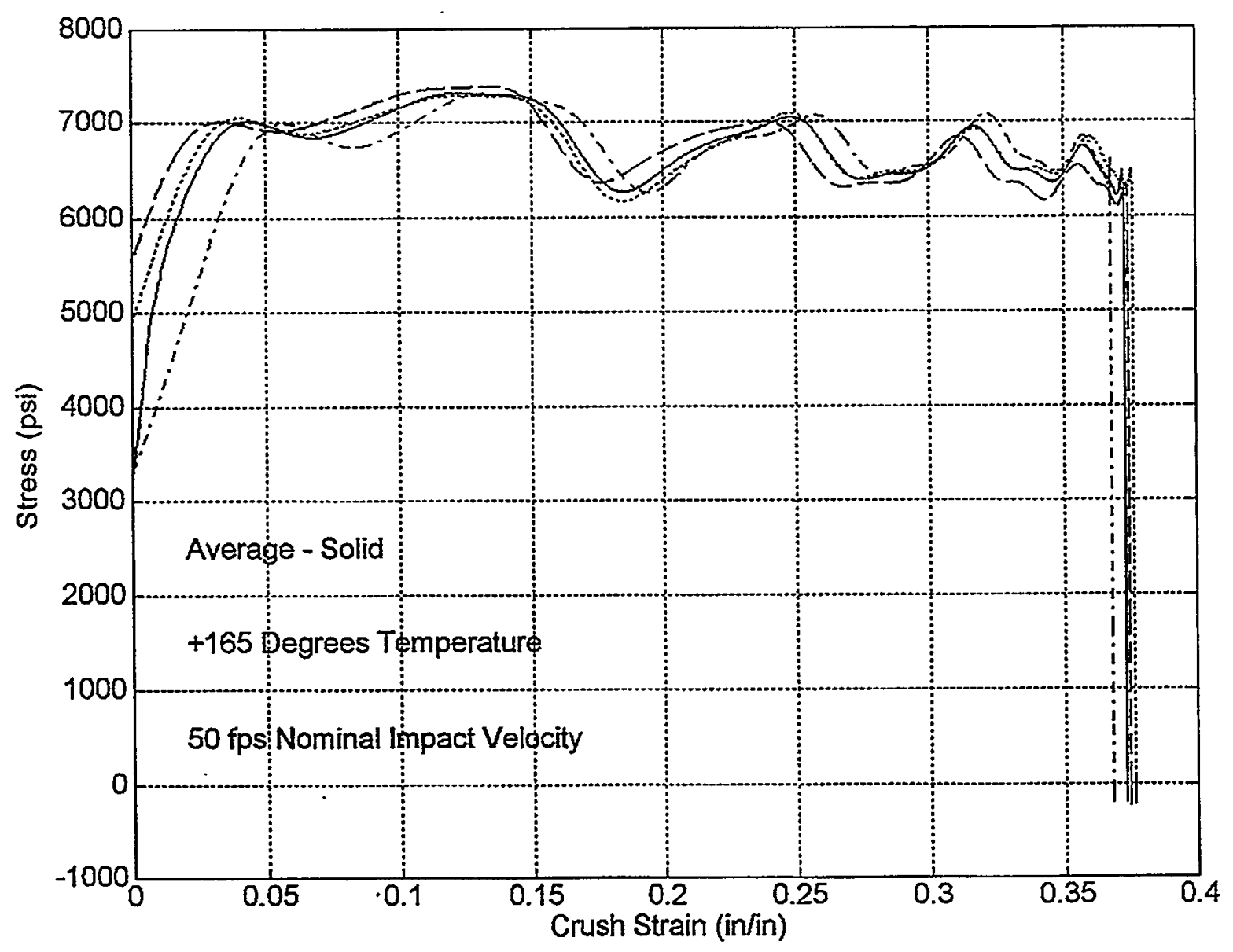

SWAT-CAL Stress Comparison, DC-2000 Hz Bandwidth (Segmented Alcore Honeycomb at $+165^{\circ} \mathrm{F}$ Temperature). 


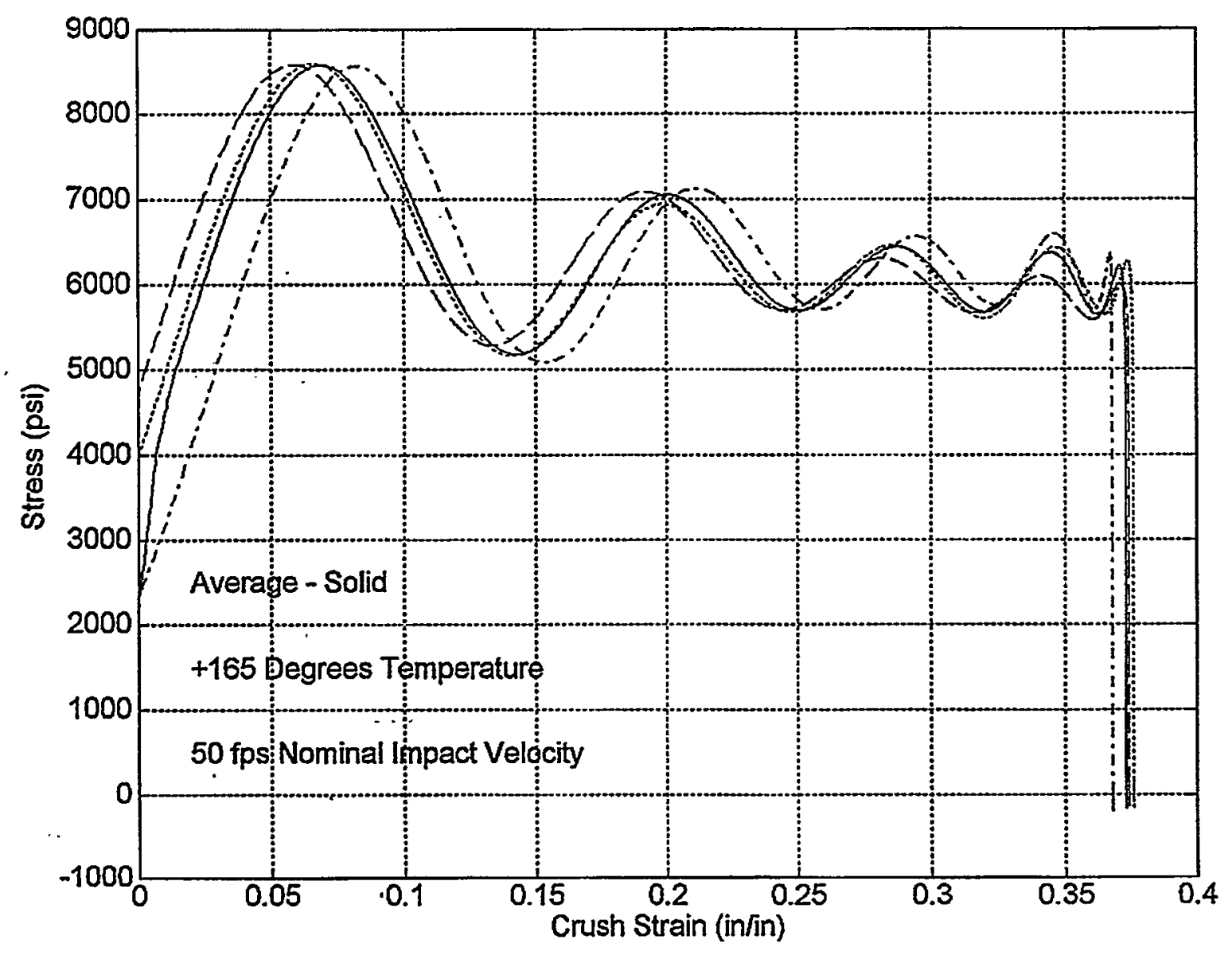

Load Cell Stress Comparison, DC-2000 Hz Bandwidth (Segmented Alcore Honeycomb at $+165^{\circ} \mathrm{F}$ Temperature). 


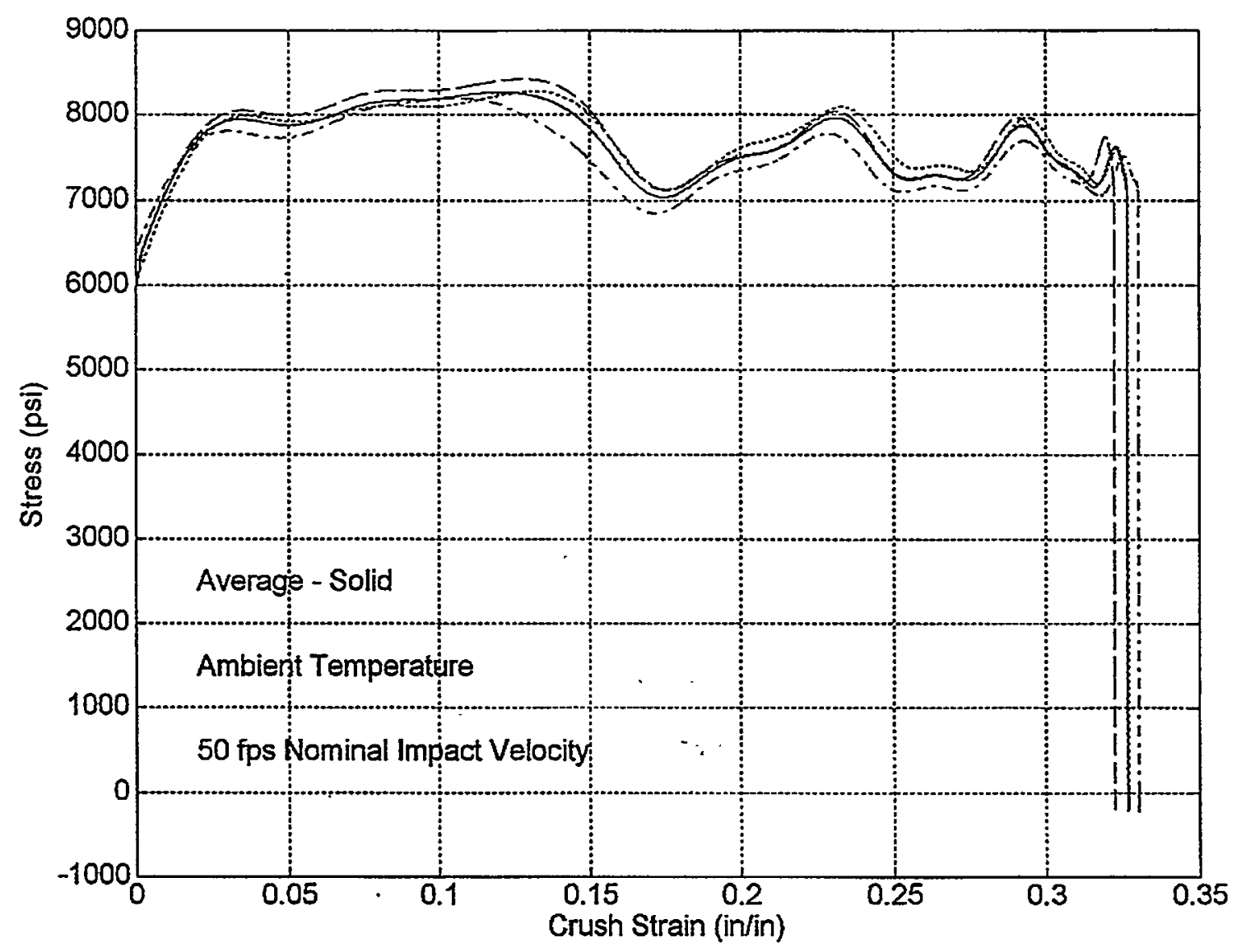

SWAT-CAL Stress Comparison, DC-2000 Hz Bandwidth (Segmented Alcore Honeycomb at Ambient Temperature). 


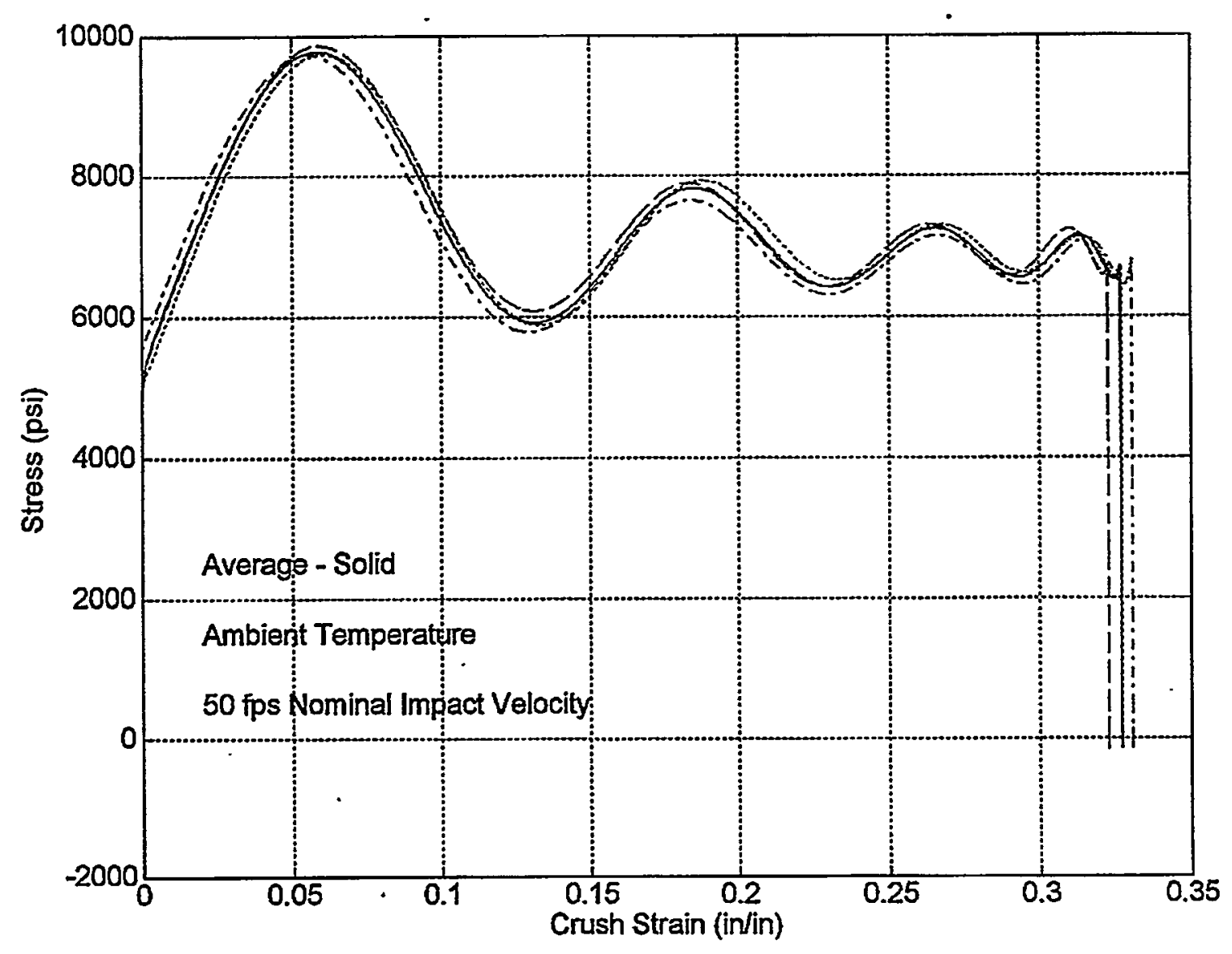

Load Cell Stress Comparison, DC-2000 Hz Bandwidth (Segmented Alcore Honeycomb at Ambient Temperature). 


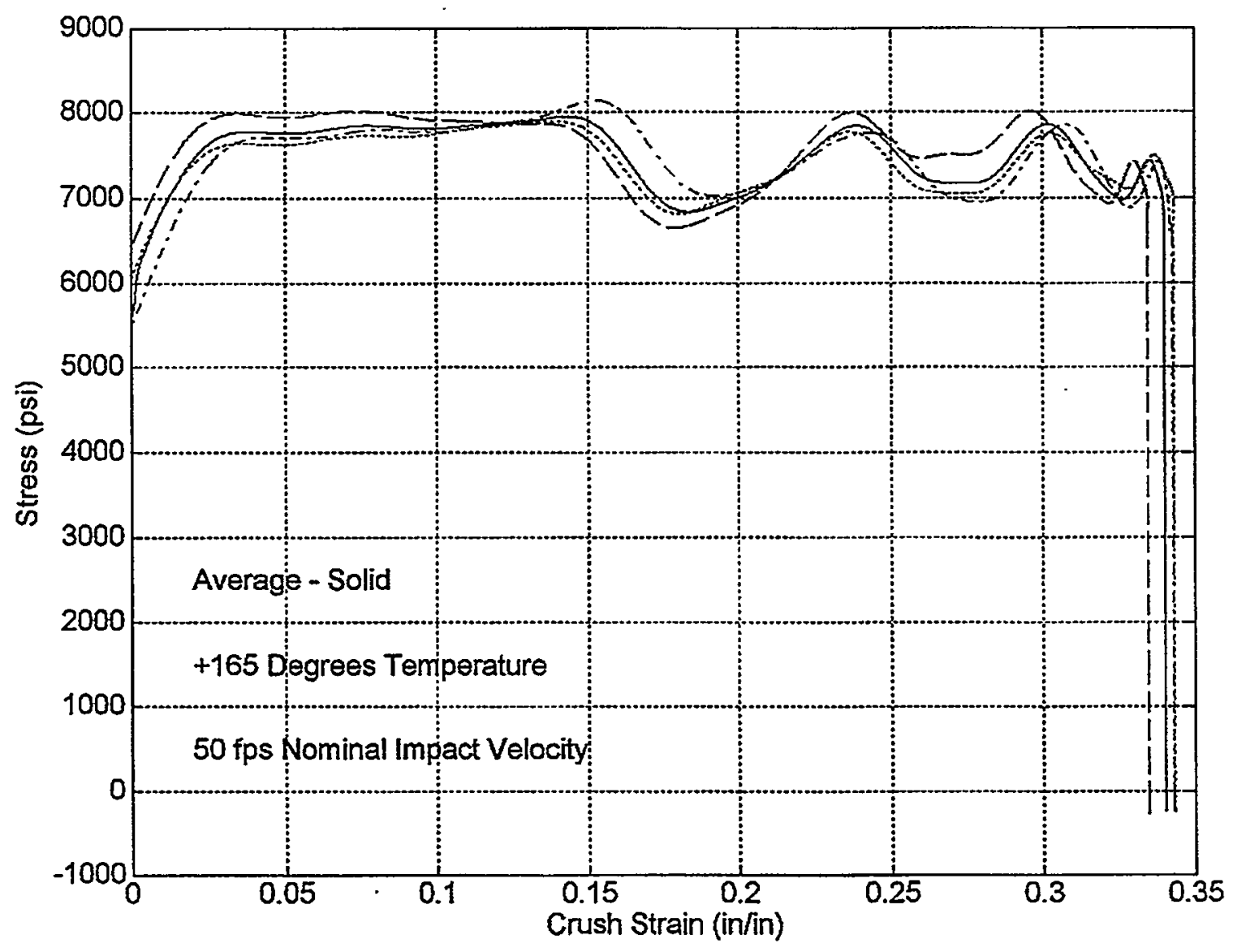

SWAT-CAL Stress Comparison, DC-2000 Hz Bandwidth (Segmented Hexcel Honeycomb at $+165^{\circ} \mathrm{F}$ Temperature). 


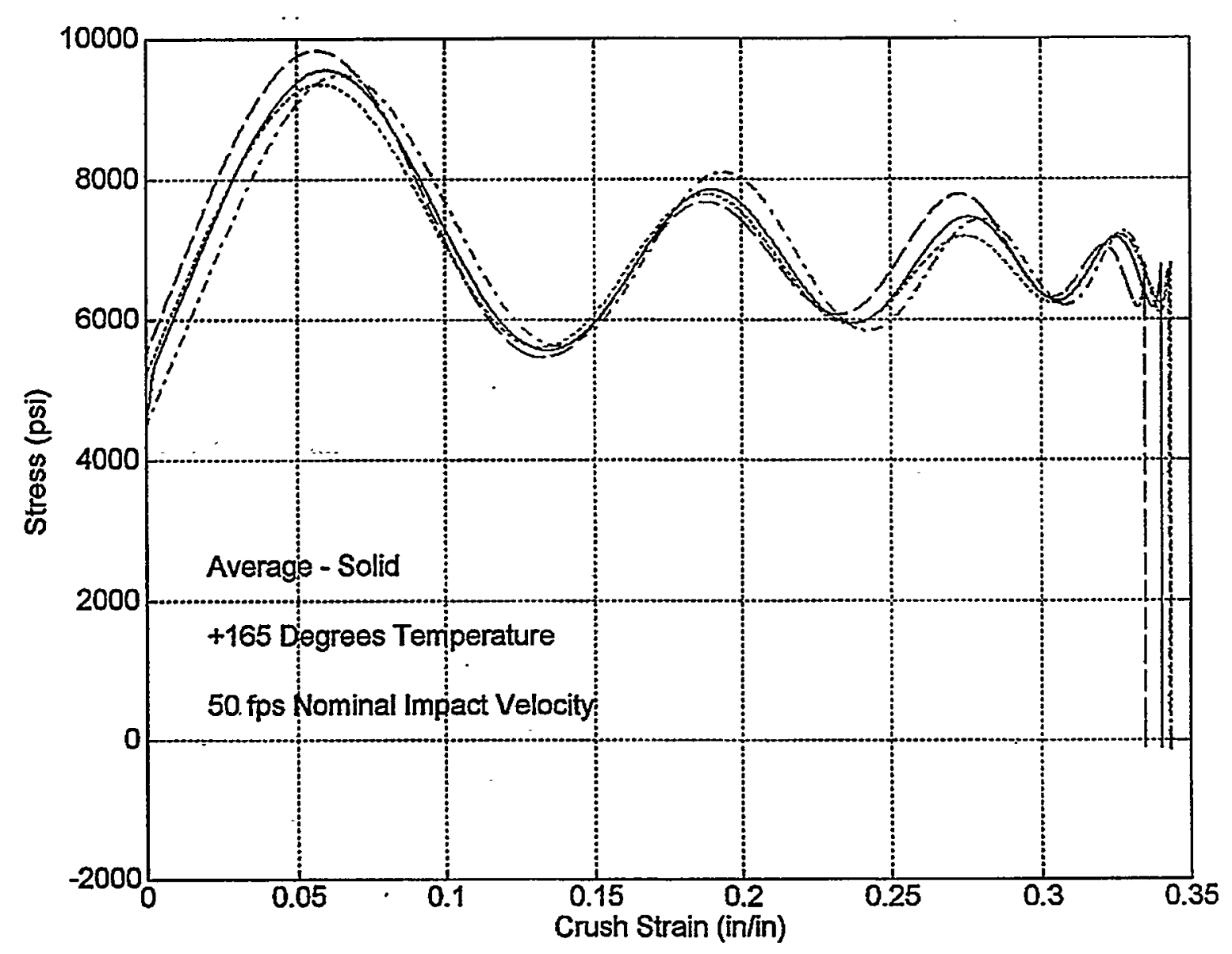

Load Cell Stress Comparison, DC-2000 Hz Bandwidth (Segmented Hexcel Honeycomb at $+165^{\circ} \mathrm{F}$ Temperature). 


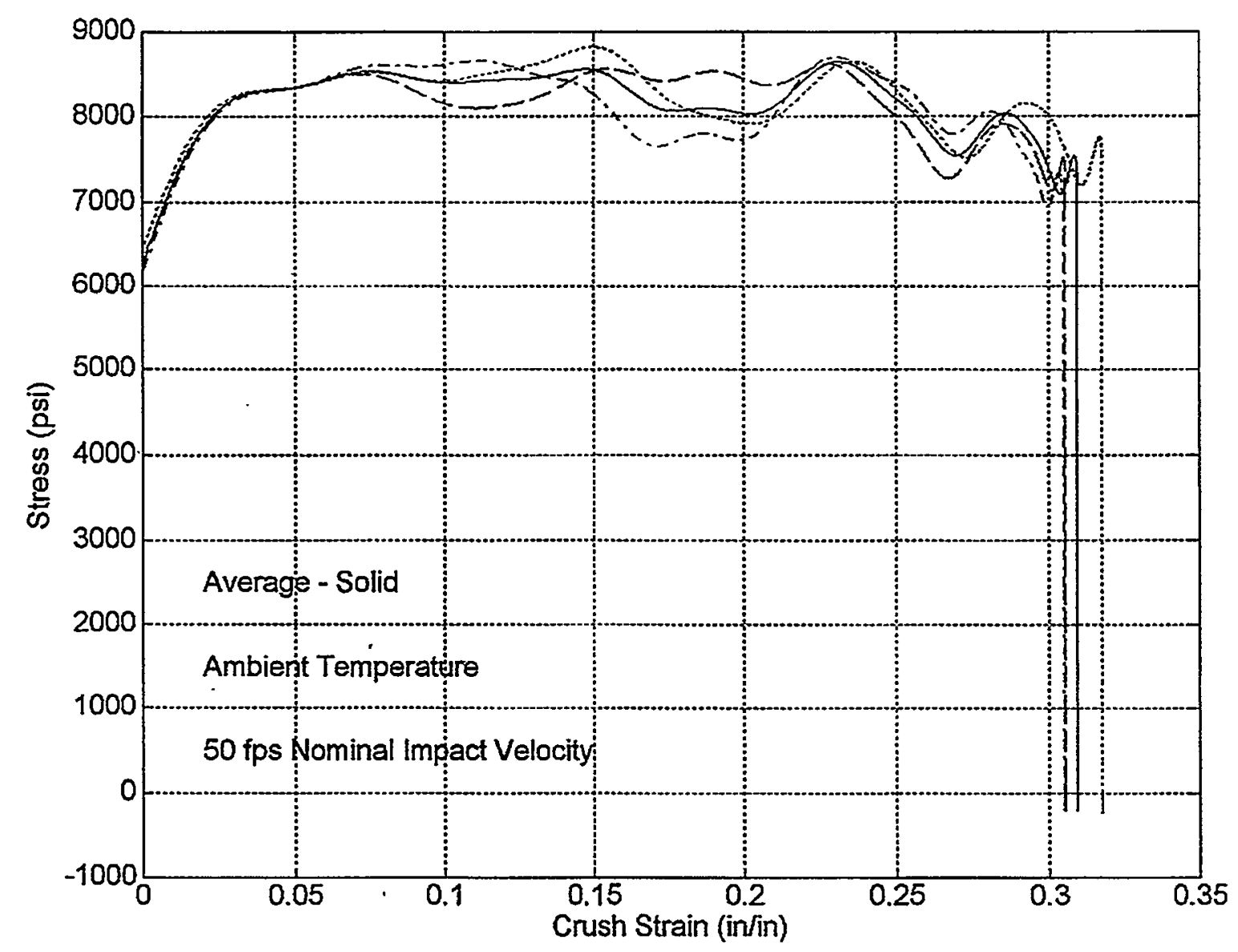

SWAT-CAL Stress Comparison, DC-2000 Hz Bandwidth (Segmented Hexcel Honeycomb at Ambient Temperature) 


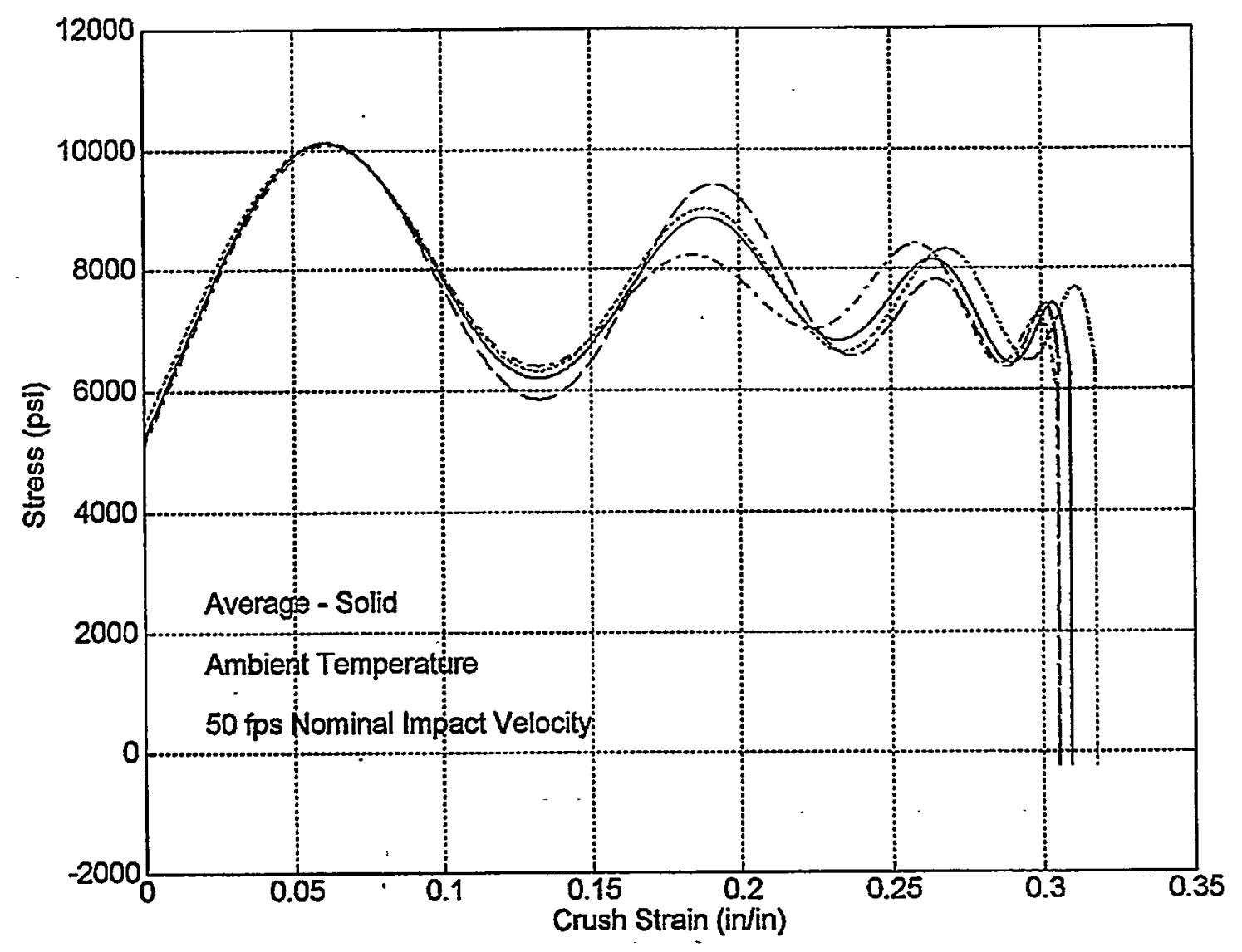

( Load Cell Stress Comparison, DC-2000 Hz Bandwidth (Segmented Hexcel Honeycomb at Ambient Temperature). 


\section{Appendix E}

\section{Pictures of Crushed Segmented Honeycomb Samples}

Nominal Undeformed Dimensions

5.08 in. Diameter and 1.50 in. Height 


\section{Alcore - Experiment 1 $+165 \mathrm{~F} \quad 50.99 \mathrm{ft} / \mathrm{sec}$}

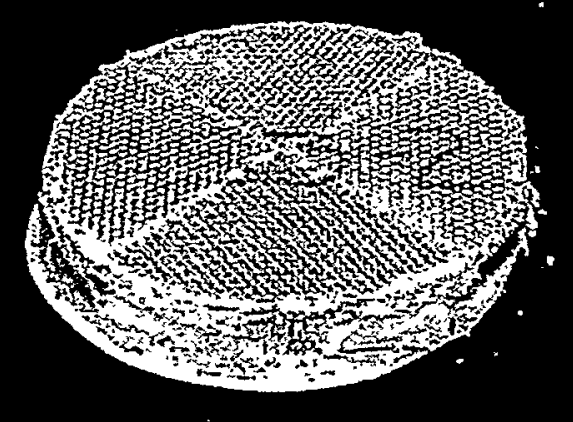

\section{Alcore - Experiment 2 $+165 \mathrm{~F} \quad 51.51 \mathrm{ft} / \mathrm{sec}$}

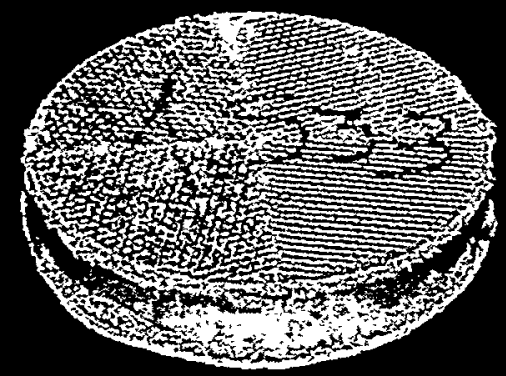




\section{Alcore - Experiment 3 $+165 \mathrm{~F} 50.66 \mathrm{ft} / \mathrm{sec}$}

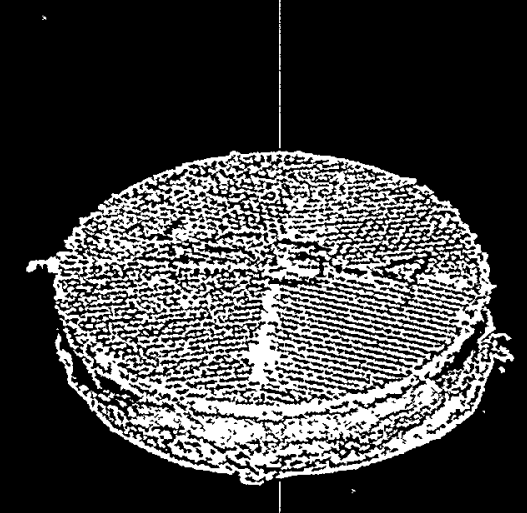

\section{Alcore - Experiment 1 Ambient $50.91 \mathrm{ft} / \mathrm{sec}$}




\section{Alcore - Experiment 2 Ambient $50.99 \mathrm{ft} / \mathrm{sec}$}

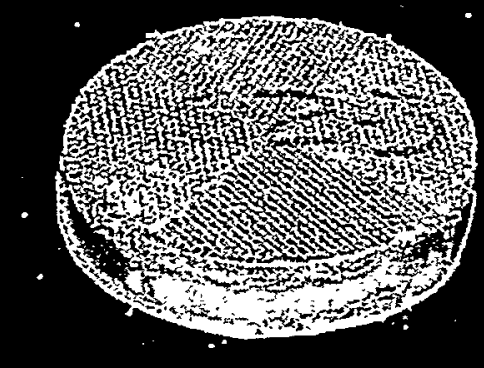

\section{Alcore - Experiment 3 Ambient $51.08 \mathrm{ft} / \mathrm{sec}$}

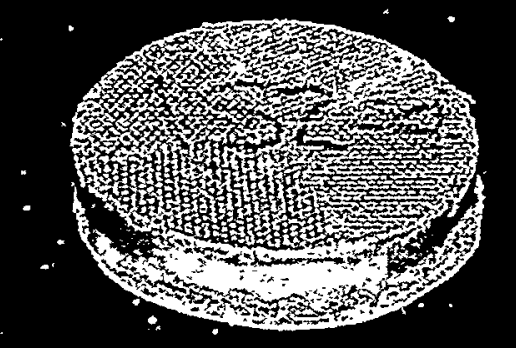


Hexcel - Experiment 1 $+165 \mathrm{~F} \quad 51.33 \mathrm{ft} / \mathrm{sec}$

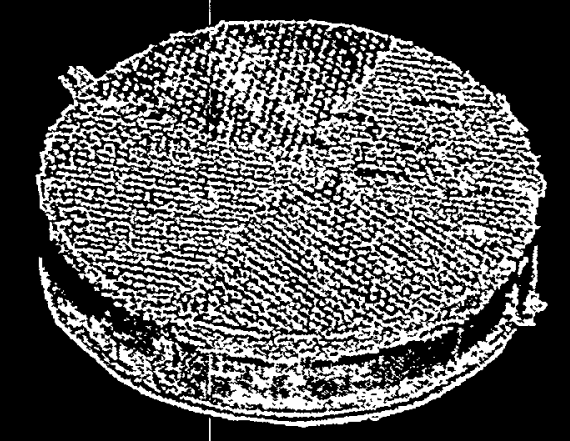

\section{Hexcel - Experiment 2 $+165 \mathrm{~F} 51.16 \mathrm{ft} / \mathrm{sec}$}




\section{Hexcel - Experiment 3 $+165 \mathrm{~F} \quad 51.42 \mathrm{ft} / \mathrm{sec}$}

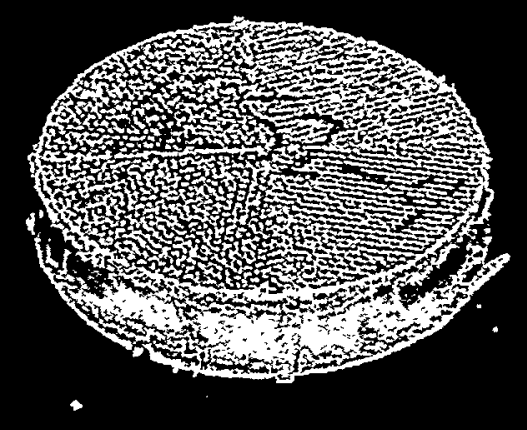

Hexcel - Experiment 1 Ambient $50.74 \mathrm{ft} / \mathrm{sec}$ 


\section{Hexcel - Experiment 2 Ambient $50.58 \mathrm{ft} / \mathrm{sec}$}

\section{Hexcel - Experiment 3 Ambient $52.02 \mathrm{ft} / \mathrm{sec}$}




\section{Distribution - External:}

1 Randall D. Cope

NAWCWPNS

Code 478600D

China Lake, CA 93555

1 Mark Gelak (Code 9520, Bldg. 559)

IHD NSWC

101 Strauss Avenue

Indian Head, MD 20640

1 M.Shannon Haataja

AMSMI-RD-ST-WF

Redstone Arsenal, AL 35898

1 Brad Hanna

NSWCDD/G22

17320 Dahlgren Road

Dahlgren, VA 22448

1 Danny Hayles

AFRL/MNMF

306 W. Eglin Blvd., Bldg. 432

Eglin AFB, FL 32542

1 George N. Hennings

NAWCWPNS

Code 478COOD

China Lake, CA 93555

1 David Hollingsworth

NAWCWPNS

Code 473320D

China Lake, CA 93555

1 Chris Janow

US Army Fuze Management Office

B1

Picatinny Arsenal, NJ 07806
1 Richard Mabry

101 West Eglin Blvd., Suite 219

WL/MNMF

Eglin AFB, FL 32542

1 Brian Mary US Army ARDEC

AMSTA-AR-CCF-A

2800 Powder Mill Road

Adelphi, MD 20783

1 David Montoya

LANL

P.O. Box 1663, MS C931

Los Alamos, NM 87545

1 Art Savarese

US Army ARDEC, Bldg. 6

Picatinny Arsenal, NJ 07806

1 Steve Smith

AFRL/MNMF

306 West Eglin Blvd., Suite 432

Eglin AFB, FL 32542

1 Peter K. Stein

5602 E. Monterosa

Phoenix, AZ 85018

1 Keith Thomas

AFRL/MNMF

101 West Eglin Blvd., Suite 246

Eglin AFB, FL 32542

1 Commander

US Army Aberdeen Test Center

ATTN: STEAC-SL-B (Mr. Scott Walton)

Building 359

Aberdeen Proving Ground, MD

21005-5059 


\section{Distribution - External (cont.):}

1 William L. Konick US Army TACOM-ARDEC, Fuze Division Attn: AMSTA-AR-CCF-A 2800 Powder Mill Road Adelphi, MD 20783-1197
1 Dr. Patrick L. Walter Texas Christian Univeristy Department of Engineering Box 298640

Fort Worth, TX 76129

\section{Distribution - Internal:}

$1 \quad \mathrm{MS0483}$

$1 \mathrm{MS0481}$

$1 \mathrm{MS0481}$

$1 \mathrm{MS0481}$

$1 \mathrm{MS0483}$

$1 \mathrm{MS0634}$

1 MS9042

1 MS9042

1 MS0828

1 MS0555

$1 \mathrm{MS0555}$

1 MS0847

1 MS0847

1 MS0847

1 MS0557

1 MS0847

6 MS0553

$1 \mathrm{MS0553}$

1 MS0847

1 MS0847

$1 \mathrm{MS0553}$

1 MS0828

1 MS0828

1 MS0453

1 MS9018

2 MS0899

$1 \mathrm{MS0612}$
T. D. Hernandez (2112)

D. A. Hoke (2112)

V. O. Willan (2112)

M. A. Rosenthal (2114)

K. W. Gwinn (2165)

D. J. Giersch (2951)

W. A. Kawahara (8725)

Wei-Yang Lu (8725)

T. C. Bickel (9100)

M. S. Garrett (9122)

M. A. Nusser (9122)

H. S. Morgan. (9123)

M. K. Neilsen (9123)

D. R. Martinez (9124)

T. G. Carne (9124)

R. A. May (9126)

V. I. Bateman (9126)

F. A. Brown (9126)

T. D. Hinnerichs (9126)

John Pott (9126)

L. H. Swanson (9126)

J. L. Moya (9132)

B. D. Boughton (9132)

N. R. Hansen (15414)

Central Technical Files

Dept. 8940-2

Technical Library (9616)

Review \& Approval Desk (9612)

For DOE/OSTI 